653

G82 


\section{LIBRARY OF CONGRESS.} Chap. So Copyright No.

$$
\text { Shelf. G822 }
$$

UNITED STATES OF AMERICA. 






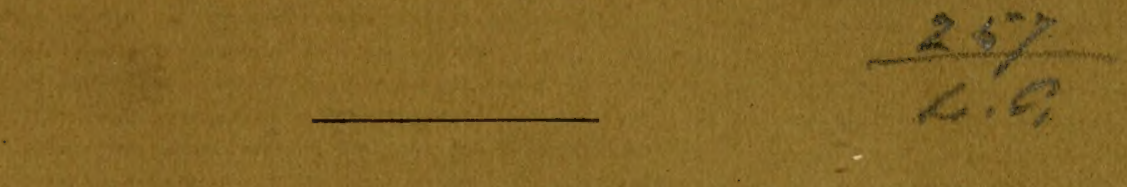

\title{
WHERE THE MATERIALsCOMES FROM.
}

\section{WHERE TO GET THEM IN THE CHEAPEST FORM.}

\section{HOW TO COMPOUND FORNULAS, ETC., ETC.}

\author{
BY \\ J. J. H. GREGORY, A.M.,
}

AUTHOR OF WORKS ON CABBAGE-RAISING, ONION-RAISING, SQUASH-RAISING, ETC.

\section{BOSTON:}

PRESS OF RAND, AVERY, \& COMPANY. 1885. 
Copxriant, 1885 ,

BY J. J. H. GREGORY.

\section{SUN $10 \quad 1885$}




\title{
FERTILIZERS.
}

\section{WHERE THE MATERIAL COMES FROM.}

\section{WHERE TO GET THEII IN THE CHEAPEST FORII.}

\section{HOW TO COMPOUND FORIIULAS, ETC., ETC.}

\author{
BY
}

J. J. H. GREGORY, A.M.,

AUTHOR OF WORKS ON CABBAGE-RAISING, ONION-RAISING, SQUASH-RAISING, ETC.
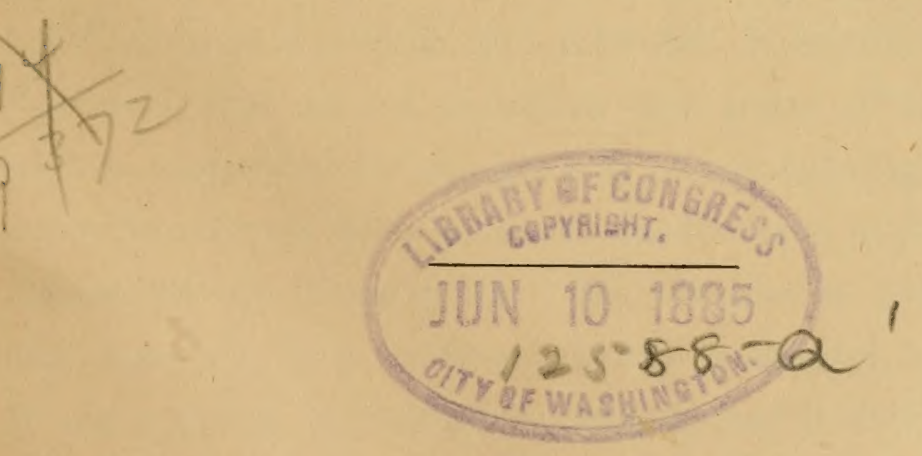

BOSTON:

PRESS OF RAND, AVERY, \& COMPANY. 1885. 
Coptright, 1885,

BY J. J. H. GREGORY.

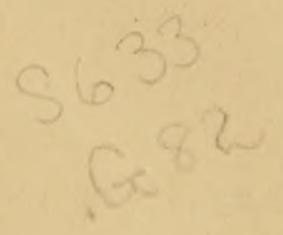




\section{PREFACE.}

Thus treatise is by a farmer for farmers. Using forty or fifty tons of commercial fertilizer's on my own crops ammually, I have been compelled to "book myself up," as the phrase is, - to learn the cheapest market in which to buy the elements, the best way to combine these, and the wisest way to apply them to the different crops of the farm. This treatise is the result of the study of various works on agricultural chemistry, especially the excellent reports that have been sent out from our agricultural stations by Professors Johnson and Atwater, Goessmam, Dabney, Caldwell, and others, to whom our sense of indehterlness will be measured by the growth of our intelligence. This study, combined with personal observation and experience, makes up my little book. My treatise is not a work on barn manure: it is confined, for the most part, to fertilizers. It can perform no miracles: to ask that it shall show every one the road to success in the profitable raising of his crops would be as reasonable as was the search of the alchemist of old for the wonderful alembic that was to transmute every thing to gold. The whole matter of soil 
action and plant-growth is wonderfully complex; and so far from the old axiom being true, that any man can be a farmer, we find that farming, in the problems it presents for solution, is a calling that challenges the best ability and the best culture to be found among men. To give a history of the three principal elements which enter into the composition of fertilizers, to discuss their relations to plant-growth in the various forms in which they exist, to tell in what form and where they may be obtained at the lowest rates, to tell how they may be combined and alllied in the wisest way, brother farmers, is the object of this treatise. Should it prove desirable to enlarge the suljject, I may take up barn and various other manures in another work.

To those who desire to study the subject of plants and plant-growth more extensively, I would recommend such excellent works as "How Crops Grow" and "How Crops Feed," by Professor Johnson; "Botanical Text-Book," by Professor Grey; and "Harris on Manures." 


\section{FERTILIZERS.}

\section{INTRODUCTION.}

Chemsts tell us that water, and this air around us, that we can neither see nor grasp, and which in all our ereryday calculations of space we take no account of, make up from eighty-eight to ninety-nine per cent of our crops. our trees, or any form of regetalle growth. Practically, we know this is so; for we can bring out in a bushel-basket all the ashes made from a load of wood that it might take a couple of yoke of oxen to draw in. A wood cord is about one hundred bushels; in the ashes which contain the minerals that entered into the make-up of that woor, we get not more than two per cent of this. The great remainder, after yielding that heat which the sun has fed to it for, it may be, a hundred years, in the form of rapor and gases hurries up the chimney, to return to mother-air, from whence they came. Plant-life builds up the mighty tree, borrowing almost nothing from the soil. It is the weight of the air and the water present in its structure that omr oxen strain under when hauling to mill the trunk of some hunge veteran of the forest. All that it has taken from the soil to make up its huge bulk the driver might carry in a bag on his shoulder, and then have to go some distance to get an appetite for breakfist. In brief, to express it in 
a familiar way, soil does but little more than help plants stand upright; while water and air, obeying chemical laws, huilr up their structure. And what is soil? It is the result of the destruction of the rocks mingled with vegetalle waste; it is the turning of all life, organic and incrganic, into its original elements; it is the great graveyard of creation; it is the great mine of the world, out from which come the food of all animal and regetable life, the wherewithal they shall be clothed, the means of shelter and protection from heat, cold, and wet; it is Mother Earth, from whom all organized life springs, and to whom, after completing its little round, all matter that enters therein returns, to repose a while within her bosom, there to rest and refresh itself before entering into new forms, and running another course of vitality.

"The earth is my mother," said Red Jacket, the Indian orator, at the Great Council, declining a chair offered him : "I mill rest upon her bosom." Yes, she is the material mother of all organized life; and, when their course is ended, all her children go home to her.

The giant of the forest may span his thousand years of time, and, towering upward a humbred feet above his fellows, may seem to despise his humble origin; but his mother is patiently waiting for him: and, hoary with year's, worn and weary, seeking rest, he bows his lofty liead, falls upon her breast, and receives her final embrace. Man himself, standing at the head of all organized life, in sleep, imago mortis, reclines by instinct on her bosom; anrl, when comes the final hour, his material self by loving hanrls is gently lowered into her yearning care, "dust unto clust." If any man could really believe that this is the find (nd, he would that instant die of horror, or become insine. 'The cheer that every grood deed leares in oux' hearts is full of the instinct of immortality. 
If we give the bushel of ashes into the hands of the chemist, to tell us what it is made of, he will return us silicon, potassium, calcium, phosphorus, sodium, aluminium, sulphur, iron, chlorine, magnesium. These are the elements that all plants take from the soil. The soil itself obtained them originally from the ledges of solid rock, which through eons of years have been slowly disintegrating and decomposing. Geology tells us, that, by the action of the drift waves of ancient eras, mountains of water six thousand feet or more in height swept from the north, breaking down, filling up, and smoothing off, the ragged, craggy surface of the ancient lava-covered earth; by later glacial action, and that of water and frost, which extend into the human period, the rocks have been ground up, and scattered over a large portion of the surface of our planet in gravelly hills and plains, covered more or less by regetable matter, through which protrude, in places, the rocky ribs of the ancient earth. This soil is but a sprinkling on the surface of our globe. At a depth of but a few hundred feet, at the utmost, on any spot of its millions of miles of surface, we would strike rock, solid to the great lava centres.

The principal ledges from which have come originally the mineral matter of the soil, are of the granite class. These yield the minerals felspar, mica, hornblende, and quartz; and they, the silicon, potash, iron, alumina, socla, lime, and manganese. The sedimentary rocks, of which the various slates are a type, have the particles in a finer form than they exist in the parent primary rocks; and hence the soils formed from these, such as the clays, hare the mineral constituents in a finer condition. But the finest subdivision of all, in which the mineral matter of the soil exists, is that supplied by dead plants and animal life, into whose structure the minerals entered in so fine a state as to be held in solution by water. 
In felspar and mica we have the great natural storehouses of potash; the former containing seventeen per cent, and the latter nine per cent. It has been estimated from tests on a small scale, that, in soils from granite taken to the depth of twenty inches on an acre of land, the potash from the felspar alone is over one million two hundred thousand pounds. What this means may be inferred when we consider that it has been computed that two cubic feet of felspar contains sufficient potash to supply the wants of an acre of young oaks for five years.

Not only is the soil of the earth to be supplied with mineral matter, but the ocean also, to enable her to furnish food for her many forms of marine life, both animal and vegetable. Water, percolating through the soil, with the help of the carbonic acid it holds in solution, which it has derived mostly from the air, dissolves an infinitesimally small portion of mineral ingredients, and carries them to the streams and rivers; and these run on, with their invisible freight of soda, potash, chlorine, and other minerals, to the ocean. Here, nothing but water being evaporated, the mineral strength increases; and in the kelps, sea-mosses, rock-weed, and eel-grass which we gather along the shore, and carry back on the land to manure our farms, or in the waste fish we handle, we find the identical manurial elements that exist in the rarious land plants which we feed to our animals. And we find, moreover, that these elements are about equally well proportioned for plantfood.

The rocks of the little State of Massachusetts have locked up in them, it is safe to say, all the potash, the silicon, the iron, the alumina, the soda, necessary to supply the population of the whole earth, from now to the end of time, with all of these ingredients that enter into their daily food, provided they were made soluble, and were 
not wasted. The soil of Massachusetts could doubtless grow food sufficient to feed a population of a million and a half of inhabitants, without a spoonful of manure being needed beyond her own natural resources, and continue to do this through all time, could, from the beginning, all excremental waste made from the consumption of such food have been returned to it. TVe say that soil is an accumulation of broken rock, decomposed minerals, and disonganized organic matter, the waste of Nature's workshop, a dead mass. And so it is, from the organic stand-point.

But there is a chemical as well as an organic life; and from this stand-point, in the loam we turn with the plough, apparently so inert and clead, there is a life of unceasing activity throughout the growing season, which rests only when paralyzed by the frosts of rinter. So complicaterl is it in its action and re-action, its marriages and clirorces, in utter clisregard of all moral laws in seeling its affinities, that it presents some of the most complicated problems to be found in physical science. The utmost that has been attained is the possible and probable. The man who could tell the world exactly the composition of a rod of ground, and the daily changes that rook place in it duxing the growing season, and how these affect the manures applied, and hcw they affect it, and how the results of these actions and re-actions affect the growing crop, would take his place among the immortals without a clissenting voice from among his fellow-men.

Chemicai action is mineral instinct, or, more accurately, a demonstration of the existence of such instinct.

Higher than mineral instinct stands plant-life. Plants have more than life, they have intelligent volition. Plantlife builds up the structure; while plant instinct, active at the little spongioles, dissolves from the rocks, or selects from the soil, with unerring accuracy, the materials needed. 
The order in creation, then, is, that the rocks supply the minerals; plants feed on these minerals; animals feed on these plants; while omnivorous man, lord of all, feeds on both minerals and plants.

Chemists have settled the fact that most of the dozen elements that enter into the composition of plants are found in sufficient quantity in almost all soils, leaving but potash, nitrogen, and phosphoric acid as the three essentials, more or less of each of which, as a general rule, we farmers must supply to the soil if we plant for a crop; though on some soils, such as muck meadows, lime and silicon in some form may be necessary arljuncts. We propose to discuss these, and the sources from which they are obtained.

Before taking up in detail the three essential elements of plant-food, let us here discuss the difference that is assumed to exist between them as they exist in barn manure and commercial fertilizers.

\section{WHAT IS THE DIFFERENCE BETWEEN BARN MANURE AND COMMERCIAL FERTILIZERS ?}

All plint-food is manure; and all manure is plant-food, whether it is in the form of the artificial products, - which are known among farmers as "artificial manures," "chemical fertilizers," - or is the natural product of the barn yard: and the feeding value of each is measured in the same way; viz., by the quantity they contain of the three essential elements, viz., nitrogen, potash, and phosphoric acid, and the digestible condition in which these elements exist. The great bugbear dealers in fertilizers have to contend with in dealing with us farmers is, the deeply rooter helief that the only real manure is that which comes out of the barnyard, and that all other forms in which it is presented are mere makeshifts. 
Where do the fertilizing elements in barn manure come from? From the food animals eat. But do all the fertilizing elements in the food find their way to the manure? Certainly not; a portion of them are used to promote the growth of the animal, going into its flesh and bones. Is there not, then, in the body of the animal, which has in it a part of the fertilizing elements contained in the food, plant-food also, as well as in the manure that passes through it? Every farmer will assent to this. As it has less water and waste in its composition than the manure itself, is it not more concentrated plant-food? Now, it is these bones, blood, flesh, and other waste that are used in fertilizer's as one of the principal sources for ammonia and phosphoric acid, - ammonia in the dried blood and flesh, and phosphoric acid in the bones, - to carry back to earth the plant-food received from it. IThat is the difference, then, between using the manure of an animal as plant-food, and using the animal himself as plant-food? Simply, that we get more water and waste in the one case than in the other.

Go into the fields, and study the crops of the Great Farmer of the miverse. From the majestic Sequoic, that tower toward high heaven, eren to the tiny hyssop, that creepeth on the wall, observe the green mantle of his mighty domain thrown over the mountains that span a continent, and trailing along their thousand valleys, contrasting, in its rast amplitude, with the patches of soil on which dwell nations, corering every latitude and enveloping all continents in its mighty folds up to the great icy circles. How does the Great Farmer raise his crops? Take rour spade, and dig down into the soil. Do you find any barn manuie there? Go out on the boundless prairies of the far West, "where bounteous nature only, tills the willing soil." Do you find any barn manure there? They waved their 
oceans of verdure thousands of year's before the human era. Enter the limitless woods, and ask the giant pines for the secret of their towering robustness. Was it barn manure?

Says Bruckner, "Farmers, accustomed to think of manure as a bulky article, want bulk for their money. They are slow to realize that a little of the substance needed is better than a good deal that is not needed."

I will say, at the outset, that this little treatise is not designed to be a tilt against barnyard manure: that will always have its place in agriculture, as I fincl, myself, in the great quantities I use annually in my own farming operations. But I would like to see the circular's of some of the dealers in fertilizers take a little bolder stand, and not say, that, after we have used all our barn manure, then comes the time to buy fertilizer's, but to declare that there are crops which can be raised decidedly cheaper on fertilizers, besides ripening earlier (as corn), and being of better quality (as potatoes), and that it would always be decidedly better to use a part or all of fertilizers on such crops, and give what manure we have remaining to the acres of grass-lands that would be fertilized by it on every farm. I contend for a broad handling of this subject of plant-food, and a recognition of the true value of it in every form in which it exists.

\section{WHAT IS BARNYARD MANURE?}

I took a little of it, fresh from the horse-stall, and clied all the water out of it on the hearth, and was surpuised at the result. On breaking it up fine, all I could find, by the closest scrutiny with the naked eye, was a mass of bits of hay, ranging from a thired of an inch loug to so small as to be barely visible, and I will defy any one with the nalied eye to find any thing else. Many of the fragments of the 
hay' had suffered so little change, that they yet shone in the light. The whole mass had a yellowish color, and smelt as manure smells; but the puzzle was, to find any thing in it that could be called manure. There were fragments of hay, a slight color, and nothing else. Now, where was the plant-food in it? The potash, ammonia, and phosphoric acid evidently must have been hidden among, or soaked into, the fragments of hay. I found, by weighing it before and after it had dried, that it lost seven-tenths of its original weight; in other words, seventenths of its weight was water. Now, fresh barnyard manure has been analyzed, and found to contain the following kind and quantity of elements :-

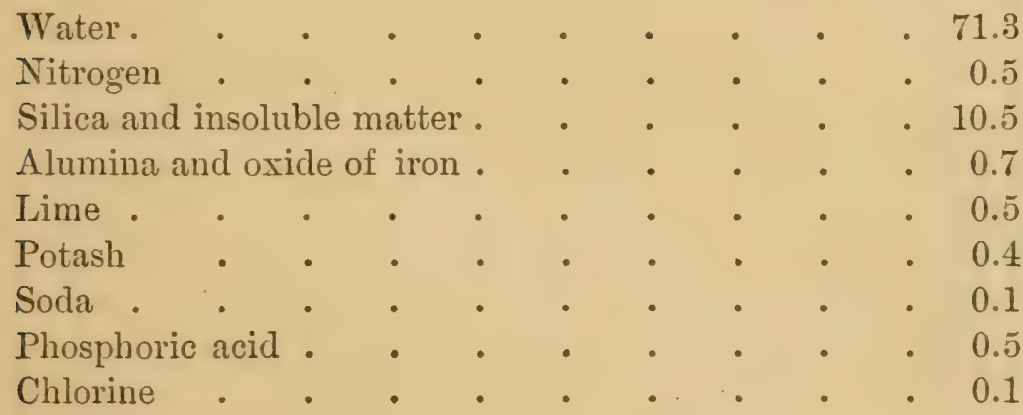

Now, taking a cord of arerage stable manure, which will average in weight about 4,500 pounds, we should have in it 3,208 pounds of water, $22 \frac{1}{2}$ pounds of nitrogen, $72 \frac{1}{2}$ pounds of silica, $31 \frac{1}{2}$ pounds of alumina and iron, $22 \frac{1}{2}$ pouncls of lime, $13 \frac{1}{2}$ pounds of magnesia, 18 pounds of potash, $4 \frac{1}{2}$ pounds of sorla, $4 \frac{1}{2}$ pounds of sulphuric acid, $22 \frac{1}{2}$ pounds of phosphoric acid, and $t^{\frac{1}{2}}$ pounds of chlorine. Taking a common one-horse load of two cord-feet, and it would contain, of water, 802 pounds ; of nitrogen, about $\tilde{s}^{\frac{1}{2}}$ pounds ; silica, about 18 pounds; of alumina, $6 \frac{1}{2}$ pounds; lime, $3 \frac{1}{2}$ pounds; magnesia, $3 \frac{1}{2}$ pounds ; potash, $4 \frac{1}{2}$ pounds; 
soda, 1 pound; sulphuric acid, 1 pound; phosphoric acil, $5 \frac{1}{2}$ pounds; chlorine, 1 pound.

Now, while you are urging on the faithful old horse, sweating and tugging at his load through the mud, into the soft ploughed ground, where the wheels sink nearly to the hubs, put on your thinking-cap, and consider that in that load you are teaming 802 pounds of water on your land; and what in the world do we want to do that for, with the ground already so wet that we don't dare stick a plough into it, and are waiting anxiously for the sum to look out with power, and dry it up? You are teaming 14 pounds of silica, which is another name for sand, - carrying coals to Newcastle; for, nine cases out of ten, the soil has already a good deal more sand in its composition than you want there. Of the iron, lime, soda, and chlorine, already, as a rule, the soil has all it needs; leaving but the nitrogen, the potash, and the phosphoric acid as the only parts of the big load that are really needed by the crop, no matter what that is to be. And the $5 \frac{1}{2}$ pounds of nitrogen, as far as weight goes, would not be a heavy load for one coatpocket, nor the $5 \frac{1}{2}$ pounds of phosphoric acid for another, nor the $4 \frac{1}{2}$ pounds of potash for the third. However, there is a little of fiction in this; for though it is literally true that all there is of value in that horse-load of manure for the production of whatever crop you intend to plant, is the nitrogen, potash, and phosphoric acid, which altogethr weigh but $15 \frac{1}{2}$ pounds, still, it is practically not possible to carry them to the field in a pure form: yet in the form of sulphate of ammonia for nitrogen, phosphate of lime from bones, and muriate of potash for potash, they would altogether weigh 52 pounds, and might easily be carried in a bushel-basket, which they would but little more than half fill, and yet have in them all the manure value contained in that two feet of manure which the old horse is tugging at. 
Why should we farmers insist upon it, that bulk is necessary in manure? We do not so insist when we use ashes, lime, or plaster; but then, we lonk upon themat least, the two latter - as agricultural miracles, though there is nothing miraculous about them. If bulk is so desirable in feeding crops, then why not, in feeding ourselves corn, eat stalk, cob, and husk? or, with the kernel of wheat, eat the straw and husk which grew with it? Just as the store of the apothecary, in the neat jar's and phials on his long, narrow shelves, supplies us all that is really valuable in a mass of medicinal herbs that in their natural state would fill his shop solid full many times over, so in commercial fertilizers we find concentrated all that is valuable as plant-food in a mass of barn manure a hundred times as bulky.

The objection sometimes urged against the use of fertilizers, that they do not leave so much food in the ground for the crop that follows, is, I consider, an argument for them. The plant-food in them is in so digestible a condition, that the crop we plant can get about all of it: whereas, in using barn manure, the food is not all in such condition; and to get the same result the first season, we must put on more manure than the crop would need, provided the ingredients became plant-food the same season. Fertilizers in some form can be made to last, like barn manure, and feed several successive crops with a single application, if it is desired. For instance, in ashes and bone we have all the three elements for a complete manure. Now apply an extra quantity of the ashes, and apply a portion of the bone in a coarse state. Ashes are always enduring in their effect; and the coarse bone will be years in decalying, and setting free nitrogen and phosphoric acid. 


\section{HUMUS.}

There is, however, a value in barn manure in addition to its fertilizing properties. Its bulk has a mechanical effect on the soil, improving heavy soils, and lightening the texture of all soils, - a fact of especial value to market gardeners in their early crops. By its partial decomposition, it adds to the mass of dark-brown earth which we so especially notice in old gardens, and which goes under the name of humus. Humus is dead vegetable and animal matter in process of decay. In the surface twelve inches of good soil, there is, in a latent condition, about fifteen hundred pounds of phosphoric acid, fifteen hundred pounds of potash, and seventeen hundred pounds of lime. Carbonic acid changes these into plant-food. Now, humus; by its decay, develops carbonic acid, and so brings about the decomposition of this latent food. TVet weather favors this action. That carbonic acid has this power to set free plant-food in the soil, has been proved by the experiments of Professor Stöckhardt. Our crops take up only a small portion of the fertilizers we apply before the nutrient substances they contain become insoluble. The humus keeps them in a soluble condition, which is an argument for the use of barn manure, muck, or the ploughing-under of sod or green crops, in connection with the use of fertilizers. It acts as a sponge, to absorb and hold moisture in low, black soils, which are made up of dead vegetable matter in a state of semi-decay, halfway towards coal, - a carbonaceous mass of stems, roots, and leaves. Burnt, it makes an ash-rerl, from the presence of iron, and having but onesixth the potash to be found in hard-wood ashes. The troulle with the humus of soil of a mucky nature for tillage purposes is, that when dry it takes up water very slowly; and it takes, therefore, a good deal of rain to 
moisten it: while, on the other hand, when wet, it keeps wet and cold too long for the health of vegetation. Without draining, manure is a waste on such soils. I once topdresserl such a meadow for two or three years, to get but wild diandelion, that was not worth the money. I deepened the outlet, and now can cut three good crops of grass from it every year.

Humus holds a great store of carbonic acid; which decomposes the minerals in the soil, setting free potash and phosphoric acid. It also holds latent nitrogen, sometimes as high as three per cent, which is six times as much as in arerage stable manure. This is made plant-food by the application of lime or carbonate of potash. It is the great argument for the use of barn manure in preference to commercial fertilizers, that it forms humus; but we can gain the same end by turning under a grass or clover sod, cow-pease, or a green crop, and these we can raise by commercial fertilizers.

Humus is not in itself plant-food. It is not necessary for the yield of heavy crops.

\section{ARE FERTILIZERS BUT STIMULANTS?}

The old-fashioned farmer is apt to look askance on this new-fangled fashion of manuring, call fertilizers "medicine, stimulants," a sure way to run out the land.

To continually apply but a single one of the three elements which enter into the complete manure, and especially if that one should be nitrogen, and for a series of years be in marked excess of the other two, would in the end, sooner or later, prove that the old farmer was right in his conciusion, however faulty he might be in his reasoning. Let me here emphasize the fact repeatedly proved, and that squares with common sense; viz., that the one of the three 
elements, nitrogen, potash, or phosphoric acid, of which the soil has the least, will always be the measure of the crop.

A hundred pounds of potash applied would not give a larger yield than five pounds (and so of the other two elements) if there is not a proportionate increase of the other elements.

Says Professor Atwater, in his generalizations from ore" a hundred carefully studied experiments, "Either the combined testimony of these experiments, similar ones elsewhere, and the best experience, are totally false, or chemical fertilizers bring larger, better, and even surer crops than farm manure. ... Artificial fertilizers rightly used must prove among the most potent means for the restoration of our agriculture." The professor makes this general recommendation: "For general farming, at a clistance from the large markets, the chief use of commercial fertilizers should be to supplement the manure of the farm. The right way is, to make the most and best manure that is practicable upon the farm, and piece out with such commercial fertilizers as experiments and experience prove profitable. At the same time, there are many cases, especially near cities, where every thing depends on getting the largest and best (and earliest) yield, where the more exclusive use of chemical fertilizers is advisable." This is sound sense; but I would modify it somewhat by adrising to use fertilizers on leachy soil in preference to barn manure, depending on occasional laying-down to grass to improve the texture of such soil. Also, as a rule, to depend on fertilizers for the vegetable and grain crops, and give the manure to the grass crop, ploughing under a good sward to enrich the land with humus, when the grass crop is as heavy as a ton to the acre, and not waiting till you can span between the blades.

The celebrated experiments of Mr. Lawes of Rotham- 
sted, Eng., when he raised wheat for twenty rears in succession, depending wholly on chemical fertilizers, the same amount each year, with the results, that, where the first ten years the average was twenty-nine bishels per acre, the second ten the average was forty-one bushe?s per acre, ought forever to settle the "stimulant and medicine" theory. Professor Atwater says, further, "That a great deal of successful farm experience goes to show that artificial fertilizers may take the place of farm manures, there is no question. The experience and experimenting that bear on this point are of too great accuracy, too long continuance, and too large amount, to be ignored, and the results too decisive to be derided. Nor is there in the results of the best scientific investigator's any thing antagonistic to the doctrine."

To sum the matter up, the arguments for the use of fertilizers are, (1) As a rule, they cost consiclerably less to produce the same crop results. (2) They are much more cheaply transported; and, containing the fertilizing elements in so condensed a form, the whole handling of them is much cheaper. (3) They supply plant-food in numberless instances where it could not otherwise be obtainerl, and so enable the farmer to cultivate much larger areas. (4) They ripen crops earlier, and so practically prolong the season, making the raising of some varieties possible when before their use they could not wisely be risked. (5) They improve the quality of potatoes and grain. They virtually bring outlying fields nearer to the farm. (7) They have indirectly raised farmer's to a higher intellectual level by stimulating them to acquire more information, and a clearer insight into the laws which govern plant-growth. (8) They lessen our crop of weeds, as, unlike barn manure, they carry with them no weed-seed into the soil. 


\section{POTASH.}

Potash is the element potassium combined with oxygen - "potassium oxide" it is caller by the agricultural chemists. Potassium itself is but a curiosity of the laboratory; for it can be kept pure only by excluding all air, and is therefore only to be found in the bottle of the chemist. The name "potash" was given it because it was made in iron pots from ashes.

In Canada and other primitive countrics, in clearing the land, the trees having been felled, piled, and burnt, the ashes are collected, mixed with about one-twentieth of lime, and placed in half-barrels, with false bottoms perforated with holes, and covered with straw. They are drenched with water; and in an hour or two the water is drawn off into shallow iron pans, and evaporated. The crude potash obtained is purified by heat on the floor of a furnace, where most of the sulphur and water is driven off, making the pearl ash of commerce.

Potash is a most caustic, biting alkali, dissolving and decomposing all organic structures it comes in contact with. It is one of the most powerful bases; in other words, it is a vigorous, unprincipled chemical thief, seizing upon, and absorbing into itself, the acids it finds combined with various saline compounds. Pure water could not dissolve the potash as it exists in the particles of felspar and mica that are found in the soil; but, taking carbonic acid from the air, it has the power of dissolving the silicate of potash, leaving the quartz and alumina to form the clays. Caustic lime also has this power. The silica, combined with the potash, preferring the lime, dirorces itself from the potash, and, marrying the lime, sets the potash free. In the regetable kingrlom it is held by plants, while in the process of growth, in a soluble state, 
combined with oxalic, tartaric, silicic, and sulphuric acids. When wood is burnt, these acids are decomposed; and, the potash combining with carbonic acid, we have the common form of carbonate of potash. Potash is not only one of the three essentials for all plant-growth, but it is also found in the fruits, regetables, and grains. The grape, the apple, the potato, are illustrations. The ashes of bean and pea vines, the potato-vine, and beet-leaves, are especially rich in potash; while com-cobs and asparagus stalls yield an enormous proportion, though but a small amount compared with their bulk. The principal sources from which we obtain potash are, India, from which comes the nitrate of potash; Germany, from which come the sulphates, muriates, kainite, kruget, etc. (all of them products of the famous Stassfurt deposit), wood ashes (which includes those from the brick-kiln and limekiln), burnt tan, logwood, etc., and a limited amount from the burnt hulls of cotton-seed. The potash in all these forms comes originally, as we have already stated, from the Creator's great storehouse, the felspar and mica bearing ledges, with the soils formed from their disintegration and decomposition. From the nitrate of potash is made the saltpetre of commerce. Being costly, it is rarely used for agricultural purposes, though, to a limited extent, a waste product enters the market.

The Stassfurt mines of Germany were originally opened for salt-mines; and what was at first looked upon as a worthless waste, the wand of Chemistry pointed out as hy far the most valuable product. These mines make, I am informed, the centre of a rast basin, many miles in diameter, which is believed to have been the bed of an ancient salt sea. The various salts, from their composition and the order of their formation, are helieved hy men of science to have resulted from the drying-nu' of this sea. The de- 
posit appears to be inexhaustible in its extent. The general name given to the potash-bearing mass is carnallite, from the pinkish color which it bears. Most of the products marketed are made from the original material of the bed by chemical processes, which, as is common in old countries, are kept well-guarderl secrets. It comes to this country in different grades of muriate, sulphate, and kainite.

The chemists tell us that a high grade of muriate of potash contains about 80 per cent of muriate of potash, which is equal to 50 per cent of potassium oxide, or pure potash. A high grade of sulphate contains about 52 per cent of sulphate of potash, which is equal to about 28 per cent of pure potash, and 30 per cent of sulphate of magnesia, which is equal to 10 per cent of magnesium oxicle. A high grade kainite contains about 30 per cent of sulphate of potash (equal to about $14 \frac{1}{2}$ per cent pure potash), 35 per cent of chloride of sodium (which is but another name for common salt), and 10 per cent of sulphate of magnesia. It generally has aiso some chloricle of magnesia.

In buying these fertilizers, we farmers are apt to think we are getting more potash than they really contain. For instance, 80 per cent of muriate of potash is apt to be taken as meaning 80 per cent of potash, whereas it means 80 per cent of potassium combined with chlorine. The quantity of potassium in the 80 per cent of pure inuriate would make 50 per cent of the weight of what we buy in lure potash: and so on of each of them. Of wood ashes, we are told that a certain quantity contains 5 per cent of carbonate of potash. Now, carbonate of potash is not fure potash, but a combination of carbonic acid (a compound of carbon and oxygen) and potash; about two parts of the five being carbonic acil, leaving but three 
parts pure potash. The cost of the potash in these combinations varies somewhat from year to year, but, at their lowest figure thus far, may be set down at seven cents per pound for the potash in the combination of sulphate, and three and three-quarters to four and one-half in muriate and kainite. One reason why the sulphate bears a higher price is, because it is sold as a purer article, costing more to produce, being especially freer from salt than either of the others.

It has been found in reality, however, that much of the so-called sulphate is really mostly muriate. Both the muriate and kainite forms have salt in their composition, which is considered injurious in its effect on some crops, especially tobacco and potatoes; affecting the quality of the lear in the former, and, by decreasing the proportion of starch, tending to make potatoes watery. Because of the heavy per cent of salt, I have found it dangerous to apply kainite in the hill where small seed, such as cabbage, are to be planted: it is better to apply it around the plants just before their second hoeing. There is a?so the objection to lainite, that it sometimes comes not purified from the chioride of magnesia, which is considered by agricultural chemists to be generally injurious to regetation. Thcse forms of the salt containing sulphate of magnesia help diffuse the potash throughout the soil, carrying in down; and hence such potash compounds (muriate oftentimes, and kainite generally) having it in their combinations are especially recommended for use when growing deep-rooting crops, such as clover, beets, etc. This combination has also another valuable characteristic, - its great power to absorb or "fix" ammonia, and so preventing its escape, being in this respect far superior to plaster.

It also has a rare and remarkable power of gathering nitrogen from the air. A chemist experimented on sereral 
heaps of barn dung which were kept for a year. In one of these, to which had been added 0.5 per cent of carbonate of lime, there was a loss of 9.78 per cent of the nitrogen. Where 1 per cent of plaster had been mixed with a heap, there was a loss of but 0.34 per cent; where 1 per cent of sulphate of magnesia had been mixed, the heap was enriched with 5.06 per cent of nitrogen; while 1 per cent of kainite added 7.97 per cent, which must have come from the air. For such reason as this, kainite becomes very valuable to sprinkle in stables, or mix in manure heaps to both fix and absorb ammonia. That word, "fix," ammonia will bear a bit of defining; and I will stop right here and define it, because it will be likely to be used again before we get through with our treatise. Ammonia in animal manure, especially the liquids, is more or less in the form of carbonate of ammonia. In this form it is volatile, and, escaping into the air, is lost. It is this that makes us sueeze when working over manure heaps. When in the form of a sulphate (i.e., sulphate of ammonia), though it can be dissolved in water, yet it is not volatile. Now, sulphuric acid likes ammonia better than it likes magnesia, while carbonic acid likes magnesia better than it does ammonia : therefore, when sulphate of magnesia and carbonate of ammonia are brought near each other, there is a mutual divorce and a remarriage all around; and, the new unions being more stable if not seclate, we have the non-volatile sulphate of ammonia and the carbonate of magnesia.

There remains yet another hearty good word to speak for kainite. Says Professor Dabney, "Lime promotes the action of kainite to a very marked degree; kainite is, by itself, frequently a proper application to swamp-lands and new lands, being also a powerful digestive agent." The action of kainite may be either a lirect one, supllying potash where potash is needed, or an indirect one, through the 
agency of the secondary salts present, such as common salt and sulphate of magnesia. These salts may promote the solution of all the plant-nourishing material in the soil ; hence the favorable action of kainite upon su'amp-lands, neuly cleared land, and all lands abounding in vegetable matter. They also benefit sandy soils by keeping them more moist. German agricultural writers adrise to apply kainite in fall or winter, or the year previous, that the chloricles may be diluted and washed down, and so be made harmless. They believe it is to be the foundation-rock of all improvement on swamp-lands, as it has already brought great blessings to the poor divellers among the bogs and moors of North Germany.

While plaster dissolves in four hundred and sixty times its weight of water, kainite dissolves in one and threefourths its weight. Some fear is felt by our agricultural chemists that farmers are using too much of these varieties of potash having so large a per cent of salt in their composition. There may be ground for this in its application to some crops. Five hundred pounds of kainite per acre would carry with it less than three bushels of salt, which, repeated for a series of years, might in the end prove hurtful to some of our crops: but much of this would pass off in the drainage of the soil; while I have, by mistake, had as high as thirty bushels applied to an acre of onions in one year, with certainly no detriment to the crop.

In his report for 1882 , Professor Dabney of the North Carolina agricultural experiment station devotes twentytwo pages to kainite and its uses. "Kainite," he says, "is now an established specific against rust in cotton, and is undoubtedly of great value, in connection with phosphate and pease, as an improver of the soil." It appears that about all brought into Carolina is in the crude state, just as mined, costing five r.17urs 1.1 .240 pounds at Stassfurt, and having an average composition of 
Sulphate of potash

Sulphate of magnesia

Chloride of magnesia

Common salt

Moisture

Insoluble matter

There is as much sulphuric acid in kainite as in sulphate of lime, which is but another name for plaster or gypsum, all three being names of the same mineral. In some instances kainite has given better results on reclaimed meadows than muriate or sulphate of potash. On sandy soil, in Germany, five hundred to eight hundred pounds of kainite, with marl or lime, produced excellent crops of pease for fodder, and gave, without additional manure, a fine after-crop of grain or potatoes. In the South the good effects of krainite has been much more marked in dry seasons. Manuring with kainite only is not wise; for the salts composing kainite are powerful digestive agents, and, though producing good crops as long as the soil contains any plant-food to be dissolved, may utterly fail afterwards, leaving the soil in far worse condition than at first.

Kainite applied to meadows or grass appeared to check the growth of the rougher grasses: it did best in combination with superphosphates and ammonia. It is the general opinion of leading agriculturists, that all the varieties of German potash do better if applied in the fall; and particularly is this true of those having soda or magnesia in their composition, as do all varieties of kainite and most of the muriates. Potatoes have done well when liainite has been applied the fall previous, but have at times been injured by the application of it at the time of planting. 'That the mischief done is mostly or wholly due to the presence of salt in the kainite, is shown by the effect of any manure 
abounding in salt. A neighbor, some years ago, used a large quantity of salt-marsh mud on his potatoes. The result was a fine crop of remarkably smooth potatoes: but he could not sell a second lot to the same customer; they were so watery as to be utterly useless for table use. Kainite, with lime or superphosphate, appears to be a special manure for pease and beans. On boggy land, where nitrogenous manures injured the crops, kainite was a success, surpassing even the richer potash salts.

\section{WOOD ASHES.}

Wood ashes are our great home source for potash. These are brought into the market from several sources, - the product of the brick-kiln, lime-kiln, or from the woods of Canada or the far West. "Wood ashes," says Professor Goessmann, "have an agricultural value much above their chemical value." The principal reason of this is, that they contain, not only potash, but all the elements of plant-food except nitrogen, and these in just the same proportions as they exist in nature, with the additional advantage of having them in a very fine state of subdirision. The main source of supply for the Eastern States has been, of late years, those brought from Canada; single firms selling several hundreds of thousands of bushels annually. The wood of different trees differs, not only in the proportion of potash, lime, and phosphoric acid in their ashes, but also in the quantity of their ashes in equal quantities by measure of wood. Professor Johnson gives the following analysis of birch, hickory, oak, and chestnut wood. In the last two columns is the analysis, by Professor Storer, of thirteen samples of unleached Canacla ashes, and also thirteen samples taken from household fires :- 


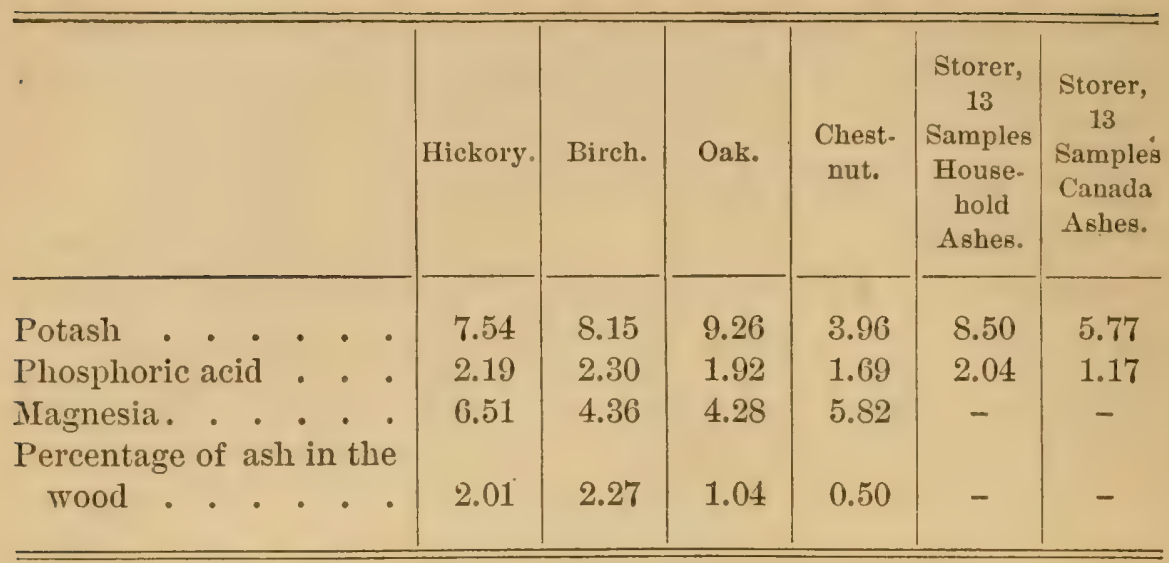

The birch was the common gray or pasture birch, which, it will be perceived, yielded more ashes than any of the others, - more than double that of the oak; while, with the exception of the oak, it was the richest in potash, and in phosphoric acid excelled either of the four. It is surmised that the sample of chestnut may have been exceptionally poor in potash. I have been often told by those who offered me the Canada ashes for sale, that, being made from primitive wood, it was richer in potash than our secondary growth. Let that fact be as it may, the analysis by Professor Storer shows that the average of the Canada ashes sold in New England are worth but about five-eighths as much as the lome product; that is, taking the potash and phosphoric acid as the measure of value, where the home-made ashes is worth thirty-two cents a bushel, the Canada would be worth but twenty cents. Says Professor Johnson, "As a cord of hickory wond weighs, on an average, about 3,500 pounds, a cord of oak from 2,300 to 2,400 pounds, from the above figures we find that the amounts of potash and phosphoric acid recoveralible in the ashes of a cord of oak and of hickory are found to be as follows:- 


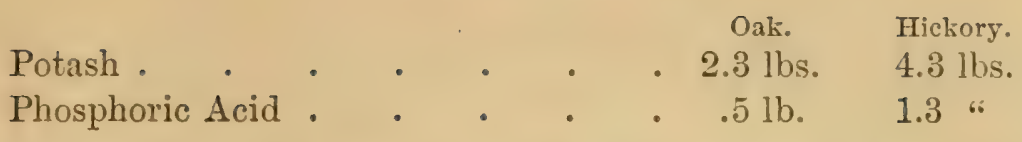

Ashes are sold, delivered at any railroad station, at prices varying with the distance and the dealer. The ashes made from burning the rood of decicluous or harclwood trees (those which shed their leaves in the fall) are nearly as strong again in potash as those made from trees of the evergreen class. Peat ashes are about one-sixth as strong as the ashes of hard-wood trees; those from the burning of bituminous coal, one-twentieth as strong; while those from anthracite are but one-sixtieth as rich. The decicluous trees differ considerably among themselves in the per cent of potash found in their ashes; the poplar, apple, elm, oak, and birch taking a high rank. Though the phosphoric acid in ashes is in an insoluble condition, ret it is so finely subdivided that it readily becomes soluble through the action of the carbonic acid present in the soil.

The price per bushel, by the car-load of about six hundred bushels, delivered in Eastern Massachusetts, is from 26 to 34 cents for unleached, and about 16 cents for leached. Three parties supply the market, each of whom has a word of criticism for his fellow-rlealers: "He has coal ashes, more or less, in what he sells." "He picks his up through agents, and linows not what he gets." "He sells more or less leached ashes for unleached." I have bought several car-loads of Messrs. Munroe \& Stroup of Oswego, N.Y., and believe that they have generally been of good quality. More or less of them are of a suspiciously light color: but I am informed that is the natural color of the ashes from elm-trees, which abound in lime; and, as the ashes taste rery strong of potash, I am inclined to believe it. The Canadians hold, that, for upland soils, the ashes made from the "black" oak are nearly worthless. 
Trees vary greatly in the richness of their ashes in potash, some being over twice as rich as others. For this reason, and the additional variation possible through fraud, all ashes ought to be bought and sold on analysis. It is true, a man may make a pretty near guess by tasting or by leaching a sample; but the test of a chemist, though a fool, can far surpass the best guess of the most experienced man. The result in the one case is a certainty ; in the other, at the best but an uncertainty. In dealing with some of the smooth-tongued fellows who have all the way to Canada between you and their facts, it is much easier to analyze the ashes than the man. Ashes have been sold as Canada unleached that proved, on analysis, to be nothing: more than oyster-shell lime having a slight admixture of wood ashes. Leached ashes contain, on an average, about 1.40 per cent of potash, and 1.24 of phosphoric acid.

Let us not forget, what has been already stated, that the potash in ashes is not pure. It is a carbonate, being about three-fifths pure potash ; that is, five pounds of carbonate of potash are equal to three pounds of pure potash. As to the value of ashes per bushel, if we allow 8 cents per pound value for the potash, and 10 cents for the phosphoric acid, then we have, for Canada ashes, $5.77 \times 8=$ $46.16+1.17 \times 10=11.70$, equals 57.86 cents for the potash and phosphoric acid present in 100 pounds: we have about 58 cents in value. If to this we add, for the lime, soda, and magnesia, 8 cents, we have 66 cents as the commercial value of 100 pounds of unleached Canada ashes; and, as a bushel weighs about 45 pounds, its value would be nearly 30 cents.

The peculiar proportion and fine condition in which the several ingredients enter into ashes, make the agricultural value considerably higher than this. The value of leached ashes maly be figured on the same basis; all the ingredients 
except the potash remaining about the same, except that the percentage of lime is increased.

These facts seem to explain why leached ashes are sometimes as valuable to the farmers as unleached. Such cases simply prove that it was not potash the crop needed so much as the lime or other ingredients which exist in the leached about equally as strong as in the unleached. In two experiments, tried two years in succession, on corn, the leached, value for value, proved to be worth more than the unleached. In giving value for value, more magnesia, lime, and soda were applied with the leached than with the unleached; and in these, rather than potash, the soil was probably deficient. Or, the better results may have been caused by the action of the lime and magnesia in their releasing elements in the soil, making its nitrogen available, or improving its texture.

Professor Ville says, that though chloride of potassium, sulphate of potassa, and the carbonate are all three soluble in water, and all three are absorbed by the roots of plants, yet chloride of potassium is inactive, the sulphate of potassa nearly so, while the carbonate gives the best results. If this is so, then it seems to follow, that potash in ashes is worth more for agricultural use than in the form in which much of it is found in the potash salts of Germany.

LOG WOOD AsHEs. - These are made from the wood or wood sawclust after the coloring-matter has been extracted. They contain but a trace of potash (.08), with 2.30 of phosphoric acid. I have had them offered at ten cents per bushel. Obviously all their value comes from their phosphoric acid.

RotTes Wood. - As bones exposed a while on the surface, part with their nitrogen to the greedy soil; so wood exposed so long as to be pretty rotten, annears to part with its potash, for I am told that little or none is found in its 
ashes. Probably this is one of the reasons why the soil from chip-waste is so good a fertilizer.

TAN AsH.- This is a very light ash, and is considered by soap-makers as very poor in potash; the lye from it being about equal in strength to pump-water, as one told me. Nevertheless, there is value in it, especially on low grass-land, probably from the lime, magnesia, ete., in its composition. It sells for a low figure, less than half the price of ordinary ashes.

Brich-Killy Ashes.- These always come mixed more or less with broken brick and burnt clay, and are worth no more than the ashes made from the wood used in burning the brick. The mass is worth from five to seventeen cerits per bushel.

Line-Kiln Ashes.-These are usually a little wood ashes mixed with five or six times their weight of particles of lime partly burnt. Some analyze of less value than airslacked lime. A few years ago I examined a sample from some thousands of bushels offered me at sixteen cents per bushel: a common sieve took out over half its weight of worthless limestone, leaving the remainder largely made up of smaller particles of the same. The lot would have been dear at eight cents per bushel.

Ashes from bushes, bark of trees, and animals, are richer in potash than those from the body wood; and those from cultivated trees are said to be richer than those made from trees of wild growth.

Bunnt Soll. - Where stumps, bushes, and sods are burned, there is left a mass of red-colored light ash-like residue. This, farmers usually call ashes. Bear in mind our axiom, that, in manure matters, nothing more can come out than goes in. The real ashes, therefore, in such heaps, must bear the usual proportion to the regetable matter burned. By this measure to guide us, we must conclude that but a 
very insignificant proportion of the ash-looking mass is ashes from burnt vegetable matter. And such is the fact: the great bulk of it is simple mineral matter from burnt soil, colored red by the action of the fire on the iron that is found in about all soils, - the same mineral that makes the white brick turn red in burning.

\section{COAL ASHES.}

Coal ashes contain no appreciable amount of potash: the chief ingredient is silica. They contain also some lime and magnesia: some assert that there is as high as 100 pounds of magnesia to the cord, with 160 pounds of sulphuric acid. The trace of potash comes from the wood used in kindling fires, and the coal itself. Theoretically, coal ashes should prove of but little value on most soils, beyond making heavy soils more open, and supplying silica to land of a muck-like character; still, there is considerable of value in them, when used in connection with manure, on some crops, especially potatoes, and around bushes and fruit-trees. Here they serve as a mulch, and, like all mulches, inclirectly improve the soil beneath them. Many of the coal ash-heaps in towns are made receptacles for the slops of the family, which turn them into manure that will pay for carting a mile or two. When night-soil is collected, they are valuable for forming the bed to receive it, and act as an excellent absorbent.

\section{COTTON-SEED HULLS.}

This is one of the sources for potash confined mostly to the South, not only because they are wholly burned there, but because the ashes are oftentimes mixed more or less with coal ashes, and charred and unburnt hulls used in the furnaces of the oil manufactories, where they are largely consumed as fuel. Because of these impurities, they are 
rarely found in the market for sale. The ashes analyze, on an average, 19.5 potash, and 9.2 phosphoric acid; nearly all of each in a soluble condition. They are usually sold at twelve dollars per ton, while the potash alone makes them worth nearly twice as much. The strong potash attracts moisture, of which there is usually 15 per cent present.

\section{THE USES OF POTASH IN AGRICULTURE.}

Potash, as we have already stated, is one of the three essentials for plant-growth. By this I do not mean to advise that it should always be applied to every crop; for there are soils alreadly so over-rich in potash and soda, that, except the wild sage and a few other shrubs, nothing will grow on them. This is the characteristic of what was known in our geographies as "the great American desert." 'The trouble was, it was over-rich in soda; but, when the Mormons at Utah diluted these with water from the mountains, the "clesert" disappeared, and in its place stands a fertile land. Some of the soils of New England, even, will bear cropping for a few rears without any application of potash : they may have good natural stores of it in plant-food form, or the potash may have accumulated in the soil through years of heavy manuring. The natural growth on any soil is a good indication as to whether or not our farms are rich in potash. If they yield a thrifty growth of potash-bearing trees or plants, such ats beech, maple, oak, walnut, or elm among trees, or tansy or purslane among plants, it is a fair inference that it is naturally rich in potash in food condition. Soils that have been manured for years with either barn manures or sea manures, have large stores of accumulated potash; and, when using commercial fertilizers on such soils, this fact might economically be borne in mind. As has been shown before, about all soils derived from granitic rock are enor- 
mously rich in potash in a latent state. Soils formed from red sandstone contain potash (usually) enough to make the application to some crops unnecessary.

It may be objected, to the above position, that the trees and plants, having taken the quantity necessary for their structure out of the ground, would leave it poor in potash. In reply, I would say that the natural potash suplly is practically inexhaustible: the thrift of the trees indicates that it is supplied as fast as plant-growth can take it ul, which is another way of stating that it is rich in arailalle potash. Clover and beans are rery sensitive to a deficiency of potash in the soil; and if we farmers wish to incuire of our land as to whether it needs potash in the fertilizers we apply, if we plant either of these, we shall get an answer. Kemp's manure-spreader is an excellent means for spreading ashes, though one would not be likely to think so on looking at it; yet it is really as good for clistributing ashes as it is manure. When filled with manure. it distributes at "the rate of four cords to the acre. Four cords are 400 bushels. Now, then, if we wish to spread any given quantity of ashes per acre, we must fill the body. just that proportion full as the quantity we desire to use on an acre is of 400 . For instance, if we ranterl to spreal 100 bushels to the acre, then we must fill it one-quarter full; for, if entirely full, it rould spread 400. And just here let me repeat, that neither potash nor phosphoric acid wastes to any extent in the soil; that is, they always remain witlin the reach of the roots of plants: and therefore any surplus left orer from one crop will be found by aftercrops.

If farmers will get into the habit of testing their soils (we shall illustrate this farther on), they might at times omit the use of potash on their crops with no loss. But it would not be wise to risk this: we should know what we 
are doing. "The result of a study of a long list of experiments," says the "Comnecticut Agricultural Report" of. 1880, "is to prove clearly that in many instances the reason why guano, fish, bone, superphosphate, and other manures fail to give a satisfactory result is, for want of potash." In cases where fish or night-soil has been used exclusively as fertilizer's for a series of years, the soil sometimes bakes, and becomes nearly sterile; the application of potash to such soils is often followed by very striking results. On land where potash did no good applied to corn, it did prove valuable to potatoes alongside: "and, if it does good under such circumstances, it might be assumed to do good to potatoes on any soil; and such is the fact." On some soils the effect of potash is very.striking. On the farm of $\mathrm{Mr}$. Sage, one of the enterprising experimenters with chemicals, potash paid him ten times its cost on corn, potatoes, oats, and wheat. A good cleal more enterprise along the line of these soil-tests would pay all of us brother farmers a heavier per cent than we ever received from any savings bank. The effect of all forms of potash is decidedly greater if applied in the fall or winter. The sulphate and muriate may be mixed with any fertilizer, as they will not free the ammonia. Unleached ashes, the agricultural chemists tell us, can be safely mixed with guano, flesh, blood, castor-ponace, cotton-seed meal, and with stable manure (if it is not in a fermenting condition), if in each instance a little soil is thrown over the mass, or they are ploughed under soon after mixing. If the ashes are first treated with sulphuric acid, $\mathrm{s})$ as to change the carbonate of potash they contain, which is rolatile, into a sulphate which is not volatile, it may then be used like the German potash salts, and be freely mixed with any manure, under any circumstances. Guano, given in the above list, I should take exception to; for, 
if either that or the ashes are damp, in my experience I founcl a loss of ammonia immerliately perceptible. If mixed with a mixture of fish and barn manure, it will hasten decomposition; and the mass should be covered with soil, to catch the ammonia.

Mr. Lawes, after his famous experiments in England, extending over a period of forty years, concludes that in his soil, which is a strong clay, potash is found naturally in sufficient quantity, and therefore no artificial supply is required. In this country, the application of potash usually has a good effect on clay soils; though, as potash enters largely into their composition, one would naturally infer the contrary. The benefits from it are thought to be due to its indirect action in opening the soil or otherwise improving its mechanical condition, and also by rendering other plant-food available. In the valuable experiments inaugurated by the Comnecticut commissioner of agriculture, it was found that potash helped the crop most on the poorer soils, while it did but little good on those that were rich. Professor Ville recommends potash especially for pease, beans, clover, lucern, flax, and potatoes. Ont of twenty-six experiments in corn-raising, it was noted by Professor Atwater, that of the three elements, viz., nitrogen, phosphoric acid, and potash, the latter did most good in five of them, proved useful in six, and in the remaining fifteen did no good. In the experiments at the Agricultural College of Maine, beans were decidedly benefited by the application of potash, while ruta-bagas were not helperl. It has been found, that, when muriate of potash and nitrate of soda are mixed together, and applied as a fertilizer, in dry seasons they dir more harm than good. It is found that plants have the power of substituting potash for syla, but the riverse does not always hold true. 


\section{WHAT IS NITROGEN?}

The air mass which surrounds the earth for a depth of about fifty miles, as it flashes through space more than twenty times swifter than a camnon-ball at the highest velocity, is made up of about four-fifths nitrogen and onefifth oxygen gas. This gives umumbered thousands of tons of nitrogen always right at hand, but never available; for human knowledge has not as yet discovered a way by which nitrogen can be economically got at for plant-food. We have to depend, for our supply, wholly on what plants and animals have incorporated into their structure; using their waste in the form of manure and dead remains, either from land or sea, for our source of supply. The ammoniated liquor from the gas-works is but the waste produced from the remains of ancient forests, which we burn as coal. The same is true of animal life as of plant life. Though over three-fourths of the air we breathe is nitrogen, though it enters so largely into the composition of our boclies, yet we have to obtain it from the animal and regetable food we eat. As the product of animal waste in drinking-water, it sometimes causes dangerous ferers. When nitrogen is combined with hydrogen, - 18 parts of hydrogen to 82 parts of nitrogen, - we have ammonia, one of the most common forms in which, from the waste of both animals and plants, nitrogen is fed to our crops.

The other most important source of nitrogen is nitric acid. 'This is a combination of nitrogen with oxygen; and nitrates, of which we see frequent mention in all works on manures, are a combination of the nitric acicl with suda, potash, and other materials, which are called bases. It is well to fix in the mind, that, in changing nitrogen to ammonia in any manure analysis, we must add 
about one-fifth to the quantity given. It appears to be the settled conviction among men of science, as the results from many experiments, that plants cannot take up pure nitrogen directly from the air. The theory is, that they are able, to a greater or less degree, to get their supply through the water, that carries it in some form in solution into the soil, and also from the air indirectly, by the soil first separating it from the air that permeates it. Still another source of natural supply for plant-growth is nitrogen in a latent conclition, that has accumulated in the soil, set free by the action of such substances as lime and plaster. There is a general belief among agriculturists, that plants have ways of collecting nitrogen still but little known; while some extremists have gone so far as to declare that there is no necessity of feeding nitrogen to our crous, for they can of themselves collect from natural sources all they require. There is a growing belief that their power to supply their wants from natural sources is greater than has hitherto been credited to them. It is found, also, that different kinds of plants have different capacities for taking up nitrogen. Clover is an example; for, though nitrogen enters largely into its composition, it has such a capacity to help itself to the good things which surround it, that it needs but very little artificial help from the manure pile: while wheat, though it needs but little nitrogen, is so dainty a feeder that it insists on a large artificial supply, from which it may pick out that little.

\section{WHERE NITROGEN OR AMMONIA COMES FROM.}

The Whste of the Fisheries. - One of the principal sources from which manufacturers olstain the ammonia in their fertilizers is from the fish waste or offal which they pick up all along the Atlantic coast, from Maine to Florida. The largest portion of the waste is 
from the fish known by various names in different localities, as "manhaden," "heart-heads," "moss-bunkers," and, in the South, as "fat-backs." These are caught in net.s, and boiled, to secure the oil, in which they are rich, at various establishments along the shore and islands of the coast. After boiling, the water and oil are pressed out of the mass, and the residue sometimes thrown into heaps, to heat and dry; at other times it is put directly into barrels, and pressed in. In this condition it is known as "pomace" or "chum." If it is to be sold as fish-guano, it is spread on large platforms to dry, after which it is ground.

As a general rule, three barrels of fish before cooking make one barrel of the chum. The fertilizer manufacturer dries and grinds it, using it crude, or treating it with acil, to make the nitrogen and phosphoric acid directly available for plant-food. Sometimes, when the catch is a large one (over two hundred thousand fishes are at times taken in a single hanl of the net, enough to load two or three vessels of fifty tons each), and the quantity of fish is larger than the oil-factories can take care of in hot weather, the surplus is sold to the neighboring farmers at the best price that can be got. These fish are oftentimes put directly on the grass-land. The effect is very stimulating, and enormous crops of grass can be raised for a few years by such annual dressings; but the final result is, the soil becomes hard, the fish have less and less effect, and the crop is almost nothing. The fish are deficient in potash, and the result is what always ultimately comes from continuous manuring with any substance which is deficient in one of the three essentials of the plant-forci. If, after grass-land gives out under the fish-system of manuring, potash he used, the fertility can he restored.

Besides the manharlen, the:e are numerons other fishwastes, all rich in nitrogen and phosphiate. On two oeca- 
sions I have purchased cargoes of spoiled herring; in one instance, nine humdred barrels, at the rate of fifty or sixty cents a barrel, which, as a barrel weighs about two hundred pounds, would be about five dollars per ton. In some instances the fish are preserved in salt, which adds onequarter or more to the weight: in others they are fresh, with the oil in them, which does not add to their value as manure, for oil is nearly pure carbon, which is of no value for that purpose; on the contrary, it hinders, somerhat, their decomposition. Occasionally, cluring the fall fishing on the fishing-bankis near the coast, a supply of pollock will ascumulate more than the market can take, when they can be purchased at a price that will make cheap) manure. A few years ago, to help sustain the marliet, I left a standing offer with our fisherman that I would pay twenty-five cents a hundred pounds for pollock: the result was twenty thousand pounds of fine large fish, weighing from eight to fifteen pounds, just out of the water, hauled to my manure heaps. A few year's ago vast quantities of waste were made in the heads, sound-bones, and entrails which accumulate at fishing-ports. These were for years dropped into the ocean as refuse. So immense was the waste, that at the Isle of Shoals, off the New-Hampshire shore, the harbor actually became so nearly closed to navigation that the inhabitants on two occasions had to dredge them out. I am told, that, beneath some of the long wharves of Gloucester, the great fishing-town of the Uniterl States, there has accumulated an almost immeasurable quantity of this bone refuse. When, a few years ago, the heads, somnd-bones, and entrails becane a market article, I used to buy it at five or six dollars a cord on board the cars: a cord weighs from three and a half to four tons. It was exceerlingly cheap manure, but a very disagreeable one to handle, the smell 
being any thing but ottar of roses, while it took a vast quantity of soil to compost it. After remaining some months, oftentimes the heads would not be fully decayed, making the mass extremely disagreeable to handle; while there could be only a rough guess made as to how much of it would become plant-food the same season it was applied. Of late years the fish are for the most part cleaned before the vessels reach port, and the waste thrown overboard. At places along the coast where bayfishing is carried on on a large scale, there can be sometimes found a liver or blubber "chum;" it being the refuse after oil is extracted from fish-liver. If a year old, it loses moisture and consequently weight, and is therefore richer. This liver chum is a pasty, sticky substance, generally sold at a figure considerably below its value by analysis. I have bought it as low as $\$ 4.50$ per ton the present season (1885); and it is rarely higher than $\$ 12$, though, by analysis, it is worth $\$ 18.83$ per ton. I would advise cutting liver refuse with sharp sand, to make it fairly fine.

Halibut "chum" is the refuse from the heads of halibut, which are cooked under high pressure, to extract the oil that exists in the bones. The result is, to leave the bones in such a state that they can easily be crumbled. Naturally, this is especially rich in phosphoric acid. It analyzes worth $\$ 19.99$ per ton, and is sold at from $\$ 6$ to $\$ 10$. This chum is usually engaged beforehand by dealer's in fertilizers; but a wide-awake man, by looking around, can generally pick up a supply. The waste of herring and mackerel at the fishing-town is sometimes made up into "chum," being first boiled, to secure whatever oil they contain. These usually contain more or less of salt, having sometimes as high as twenty per cent, which makes them about as salt as lianite; and, like the 
potäsh-lyearing mineral, they therefore need to be used with some care, lest the proportion of salt present injure the roots of growing plants.

There is another waste of the fisheries which has come into the market of late years: I refer to the skins, bones, and fins of salted fish. These come from the fish that are stripped, and sold, boxed, free of bones. It is a heary article, and the strips come a little tangled. Fertilizer manufacturers usually monopolize this; though it can sometimes be picked up at Gloucester, Mass., at from $\$ 3.75$ to $\$ 15$ per ton.

Dog-fish, which is another name for a small species of shark, in the summer season swarm along the New-England coast, on the inner fishing-banks, driving away most other varieties. They weigh from five to ten pounds. They are very easily caught, and, their muscles being very firm, are rich as manure. The great trouble in manipulating these las been because, the flesh being of a sticky and oily nature, acid will not readily act on it. Still, they are used very largely, as a source for ammonia, by one large fertilizer manufacturer in the vicinity of Boston, who composts them with hor'se manure, and, I infer, lets his compost heaps remain two years before using, when the objection disippears. Being so abundant along the coast, and so cheal, being sold, wholesale, at $\$ 1$ a hundred fish, they are well worthy the attention of farmers who live along the shore; for, though it might be necessary to keep them over a year, the inrestment would pay an interest of some hundred per cent. The fishermen in many localities would catch them if there was a market for them. The oil from the liver's averages about a cent each fish; and, with one cent from the livers and another for the fish itself, cuite a fair business can be done during the hot months.

Wiste salt that has been once used on fish contains in 
it some fish-waste, such as blood, and particles of the flesh and scales of the fish; for this reason, it has some value as manure, in addition to its action on crops as salt. The fish-scales analyze in the vicinity of sixteen per cent in ammonia, and forty cents in phosphate of lime: they decompose more slowly than the flesh of the fish. Fishmanure, having the same origin as Peruvian guano, has the same constituents, but not in the same proportion; for ages of decay have reduced the guano greatly in bulk, and in the same proportion have concentrated it. All forms of "chum" have a large proportion of water in their composition. The fish-heads and back-bones have as high as 66 per cent: the chum pressed by a hand press has about 50 per cent, and that from a hydraulic press about 40 per cent. The average of the whole fish, as taken from the water, is about 80 per cent. The fish-grano made from dried fish-waste, contains, on an average, 7.8 per cent of nitrogen. In making fish-guano, the waste is dried in the sun or by waste steam, and, when sufficiently dry, is ground, and sold at about $\$ 33$ per ton.

The shells of lobsters, of which vast quantities accumulate at canning-factories, are ground up, and sold as plantfood. They are a complete manure, and esperially rich in nitrogen : analyzing, nitrogen, 6.2 ; potash, 0.2 ; phosphoric acid, 2.3.

HOW TO HANDLE FISH-IVASTE, AND THE BEST WAI TO FEED IT TO THE CROPS.

All fish-waste used in a crude state, as might be inferrecl from its composition, is very stimulating, and, being purchased at a low figure, is oftentimes userl by farmer's with a very liberal hamd. As a consequence, their crops are sometimes "burned up," as the phrase is. They are apt to infer, that, if they cannot see the presence of the fish in 
any part of the soil of the compost heaps as they pritch it orer, such soil can have no richness. Now, one of the wonlerful properties of dry soil is the avidity with which it takes ammonia to itself; and it may always be safely inferred, that, in a well-mixed compost heap of fish-waste, the ammonia has diffused itself through every portion of it; and, all portions being assumed to be rich plant-food, it should be used accordingly. Owing to the great richness of manure made from fish in bulk, it is wiser, even after composting it, to use it broadcast, rather than in the hill. Fish "chum," or "pomace," may be used either broadcast and harrowed in, or by first composting with poor manure, to enrich the same. If, after being broken up fine, it is put in thin layers with the manure, it will help the derelopment of heat, which will tend to fine it up, so that it will combine with the mass when it is pitched over. A thirel way is, to compost it with soil, waste turf, muck, or sawdust. In either way it is composted, it is always good farming to take careful notes of how many barrels go into the heap, that from that we may know how much of potash, ammonia, and phosphoric acid we are applying to any given crop, and govern ourselves accordingly. There are two mistakes made in applying too heavily to one to applying too sparingly.

It is surprising how penetrating is the ammonia from fish-compost. For this reason, in making a heap, the bottom layer of soil should be a foot or more in thickness. I have seen cases, where the fish was mixed liberally, where the soil was full of ammonia for several feet below the surface. In making the compost heap, after spreacling the bottom layer, which should be thicker when whole fish or the coarser waste is used, cover this with sufficient waste to just hicle the soil ; then cover with sod or soil about six times the depth of the fish; and thus proceed, scattering 
raw ground plaster over each layer of fish before covering with soil, at the rate of fifty pounds of plaster to three huncherl weight of fish. After the pile has been built up) four or five feet in height, surround the entire heap (it should be on level ground) with a little embankment of fine soil. This will catch the liquid that often rums from it when the fish begins to decompose, as well as catch what may be soaked from it by heavy rains; while it will also be handy to fill up the holes that are apt to show themselves in the top as the decomposition progresses, letting out bad odors unless they are promptly closed. Is the presence of oil or salt tends to check decomposition, fishwaste containing much of either of these had better be composted with stable manure rather than soil, as the heat from the manure will start decomposition. If decompusition is slow to start, unleached ashes or lime and plaster may be mixed with the mass; but be sure to corer such heaps with soil. The compost heaps, when manure is not used, should be macle, if possible, before warm weather closes; and, should no heat be found by driving a bar down, and testing it, after it has lain a couple of wecks, then pitch it over, to let the air in, and cover the outsicio lightly with soil. Where chum is used, after having been made fine, it can be applied directly to the surface of tillage land in the fall, and harrowed in, or be ploughed lightly under, to be thrown up near the surface loy a deeper ploughing in the spring. If left on the surfice, I find it is spreading a table all winter long for the crovs of the country.

By applying the chum in the fall, it will have the actrantage of rain and frost to help subdivide and dissolve it. Fish-skins, when used on tillage land, had better first be composted. If to be used on sward-land for grass, spread thin in the fall or very early spring. 
HOW MUCH FISH-WASTE SHOULD BE USED TO THE ACRE?

To determine this, we must consider two points. First, what proportion of it will malie digestible plant-food the first season? and secondly, what and how mucin of the phosphoric acid and ammonia found in them do the crops we propose to raise require? I think we can assume, as a general truth, that about all the ammonia becomes plantfood the same season it is applied, while not much orer one-half of the phosphoric acid can be safely counted on. If we use fish-waste on the same land the second year, we may assume that all the phosphoric acicl is available; for by that time the half left over from last season will have decomposed.

As has been stated, waste fish, particularly manhaden, are often used along the seacoast as a top-clressing for grass. This is a great forcing process, and for a while enormous crops of hay can be grown; but eventually, especially on light soil, the crops grow less and less, when generally a larger quantity of fish is applied, resulting in still more harm, until the soil utterly refuses to respond, bakes hard, and becomes apparently barren. The trouble is, it has had an enormous application of ammonia and phosphoric acid, but nearly none of potash; and the result is what always will ultimately happen on any soil when one of the three elements of fertilizers is left out. Such soils are dying for: want of potash. To recuperate them, apply potash, or manures rich in potash, and their fertility can be restored. Soil abounding in clay will stand fish-manuring without showing injury longer than those of a gravelly character. 


\section{OTHER SOURCES FOR NITROGEN.}

Peruvian Guano, Sulphate of Ammonia, Nitrate of Potash, Nitrate of Soda, Castor-Pomace, Azotin, Ammonite, Tankage, Dried Blood, Cotton-Seed Waste, Hoof and Horn Shavings, and Leather-Waste.

(An analysis of the abore will be found in the table on pp. 111,112.)

As this treatise is to be for the most part confined to those sources of crop-food, which, by way of contrast with barnyard and the more common class of manures, are called "fertilizers," I will not go into details relative to several of the sources from which nitrogen may be obtained, as this would make my treatise too extensive. If the public should appear to desire a more extended work, containing all the manure resources, I may write it at a future clay.

At the head of fertilizers, as distinguished from barn manure, stands guano. This may be defined as rotten sea-bird dung, with the remains of birds mixed with it. It is found on thousands of islands, but only on a few of these in large quantities. Being manure of bircls that feed on fish, it would always contain the same manure elements as fish, but that the rain dissolves and washes out the ammonia, leaving but the phosphate behind. Near Peru, howerer, there are a few islands lying in a region where no rain falls; as what would otherwise be the rain-bearing wind for the region loses all its moisture by the time it passes over the high, dry tops of the lofty Andes Moumtains. These islands yield a guano rich in ammonia. There are several kinds of guano in the market, knomm as Rectified, Guaranteed, Standard, Lobos, Navassa, Caril)bean, etc. The first three named are varieties of the Peruvian (sometimes also callerl Chincha, or Grunape, to designate the localities from which they were obtained), all rich in ammonia, - Standard containing nine to ten per cent, Lobos five to five and one-half, and Guaranteed six to 
seven. Each is rich in phosphoric acid, nearly all soluble, and has from two to three per cent of potash. The Navassa and Caribbean-sea guanos are rich in insoluble phosphoric acid, but are entirely wanting in nitrogen or potash. The Standard is quoted me at the time of writing, February, 1885, by Seth Chapman's Son \& Co., No. 170 Front Street, New-York City, at $\$ 63$ per ton of 2,240 pounds, and the Lobos at $\$ 48$. 'Their published analysis gives to the former' nine to ten per cent ammonia, twelve per cent phosphoric acid, and three per cent potash.

It is claimed that the nitrogen in the guano has a value over that contained in manure, into which enters fish blood or meat as a supply of ammonia, and hence called "organic nitrogen," inasmuch as in the guano it is in a form ready to be taken up by plants, while the fish blood and meat must first enter into a state of putrefaction, when some of the nitrogen is set free in a pure state, and, being, in that condition, inert as plant-food, is partly lost to the plant. This loss has been estimated to be from one-sixth to one-third the total amount of nitrogen contained in the substance. Be the reason what it may, no one fertilizer has given such universal satisfaction as guano. It, indeed, is the standard by which we almost instinctively measure the value of all other fertilizers. It having been asserted. that about all the guano sold of recent years was an artificial product, made from fish as a base, with enough of real guano added to give the guano color to the fertilizer, I wrote about the matter to Seth Chapman's Son \& Co., who are the agents for the sale of this fertilizer. In justice to them, I publish their reply:-

Mr. J. J. H. GREGoRY, Marblehead, Mass.

New YoRK, Feb. 5, 1885.

Dectr Sir, - Yours of the 4 th inst. is received. Tre have heard more or less about adulteration of Peruvian guano ever since Messrs. Hurtado \& Co. commenced making it of uniform quality by mixing cargoes of differ- 
ent analyses, some nine years ago; hut we have never been able to learn that any thing was added to it other than sulphate of ammonia. This, which is the same form of ammonia found in Peruvian guano, is usecl to bring up the percentage to the standard when the guano is deficient. We can supply the crude guano in sealed bags, as imported, and furnish a copy of analysis, which is not guaranteed; nor is any allowance made for stones. Price, same as Standard, 863 for 2,240 pounds; and analyses said to be the same.

\section{Yours respectfully,}

SETH CHAPMAN'S SON \& CO.

From this we learn that it is still possible to olstain guano in the original, unbroken packages, directly from the guano islands, though it will be more or less lumpy, and there may be some stones among it. Messrs. Chapman \& Co. quote, Feb. 6,1885 , guano in original bags per ton of 2,240 pounds, $\$ 63$; Standard, $\$ 63$; Lobos, $\$ 48$. This price is at their store, for which cartage to the cars is $\$ 1.25$ per ton. After paying freight, I have found the price to be several clollars per ton cheaper than the same quality of guano is sold at nearer home. Farmers, in buying, should remember the difference in quality between Lobos and the Standard, and should see that the price corresponds. I am told of an instance in Central Massachusetts, where last season a party mixed a little guano with salt-cake, as the residue of the manufacture of sulphuric acid is called, and sold five hundred tons of the stuff as a fertilizer. He was prosecuted, but, being a lawyer himself, found some loophole in the law, through which he crawled.

It is proper to state just here, that the fertilizer's in the market into whose name the word "guano" enters, however good they may be, have not now, as far as I can learn, a particle of Peruvian guano in their composition. I must also add, that dealers in fertilizers assert that the amount of real Peruvian guano imported is but trivial compared with the quantity sold under that name, and 
that some of that imported into this country from England has been found to be grossly adulterated. All that we farmers can do is, to buy it under a warrant that it contains given quantities of nitrogen, phosphorie acid, and potash. Mr. Chapman says in his letter, that, in bringing the nitrogen up to that required for Standard, sulphate of anmonia was used. Assuming this to be so, and that it is not obtained from any organic source, then it would be of the same value as though obtained from the guano itself. From tests I made on grass-land, I found that the Peruvian guano I purchased of Messrs. Chapman \& Co. starterl the grass earlier than did an equal value of sulphate of ammonia applied at the same time, side by side, on an equal area. This sitisfied me that its nitrogen was not derived wholly, if at all, from waste fish or meat.

Ten year's ago the New York Agricultural Society took up the matter of the adulteration of Peruvian guano, purchased eleven bag's of as many dealers, and had them analyzed. The result was a ralue cliffering from $\$ 38.33$ to $\$ 107.68$, though each was sold at the same price per ton. In the report of the Connecticut agricultural station for 1881, it is stated, that, while Peruvian guano used formerly to contain no more than one or two per cent each of socla, sulphuric acid, and chlorine, the sample analyzed that year contained about thirteen per cent of sulphate of sodia (salt-cake), and eleven per cent of common salt.

The Chincha Islands, which have been the great source, in past yeur's, of Perurian guano, lie near the coast of Peru, barren granite rocks, with great depth of water close by them, so that in places the largest ressels can lay alongside and be loaded from the land by a shout entering into their holds. The guano, a thoroughly rotted mass of bird-clung, in which are mixed feather's. carcasses, and eggs, was from four to a hundred feet in deptl. 
Old salts tell me that they brought up the same material from deep loottom on the flukes of their anchors. Had they said it looked the same, I should have believed them. From twelve to fifteen million tons have been taken from the Chincha Islands alone. Bat guano is sometimes extensively found in large caves in various parts of the world, but it varies greatly in quality.

In applying guano, the Standard, which is especially rich in ammonia, should be applied to those crops which are especially ammonia-loving; while the Lobos should be used on those which need phosphoric acid more than they do ammonia. The potash required beyond what the guano contains may be added from muriate or sulphate of potash. The quantity to be used will vary with the condition of the soil in natural strength and richness by manuring in past years, the range being from two hundred and fifty to eight hundred pounds per acre. The manner of applying will depend somewhat on the crops to be raised; but a good general rule is, to apply a part before the crop is planted, and make one or two applications at different stages of its growth. If scattered broadcast, it should be harrowed in at once, to prevent the escape of ammonia. That used in clrills, I find it easy to mix thoroughly with the soil by dragging through the furrow the top of a stocky red cedar, to which a stone weighing eight or ten pounds has been firmly tied; or, a brush-broom similarly weighted answers very well. When used in the hill, the farmers who employ help will need to look sharply after them; for I find but very few farmhands take the care necessary to so thoroughly incorporate it in the soil as to prevent the destroying of the young plants. In all our handling of this powerful manure, we must bear in mind the danger of bringing it in contact with the young roots of the sprouting seed. I recall, that, 
a dozen years ago, a foreman, who assured me he knew all about the handling of guano, planted for me a couple of acres of cabbage. A few days after they had broken ground, I noticed the rery dark color of the leaves, and, mistrusting the cause, ran my finger's under the plants, and brought up the pure guano. All that piece was replanted.

To insure, as near as possible, a thorough admixture with the soil in hill-planting, I have a rule for each man, after the guano has been scattered over an area as large as a dinner-plate, after covering it shallow, to draw his sixtined fork three times through it one way, three times through it the opposite way, and then, holding his fork perpendicularly in the middle, give it a twist around. Some advocate mixing it with two or three times its bulk of earth before applying it. While this insures a thorough mixture with the soil, it adds considerable work to the labor of distribution; and, since the plan of dragging the cedarboughs in the drill has worked well, I haved adopted that as a saving of time. Howerer, whenever there is any thing of a breeze blowing, it is wise to adopt some such plan; otherwise your neighbor's fields will be apt to share the manure with you. Let me here say, that I have found it an excellent plan, when distributing fertilizers, to take the earlier part of the day; for I find that, as a rule, the calmest portion. It is a good plan, in handling almost any fertilizer, except guano, - a little damp soil will answer for this, to have plenty of water at hand, and pour a half-bucket now and then into the barrel you are spreading from; then stir it with a hoe until, while dry enough to spread freely, it is too damp to blow away. If applying to the surface, always do it, if possible, just before a rain. I sometimes use it on onions, to hurry up the bottoming of the crops, - about two hundred pounds to the acre. Haring scattered it with the hand, immediately follow with a 
slicle-hoe, to work as much of it as possible into the soil, and so save loss of ammonia. This is an excellent fertilizer to use, in connection with barnyard manure, in the early season, to give the crops a start.

Market gardeners in the vicinity of our large cities have but very little respect for phosphate and special fertilizers, but, using from ten to twelve cords of stable manure to the acre, think highly of guano at the rate of a thousand pounds, or bone at the rate of two thousand pounds, per acre as an adjunct; or, when stable manure alone is to be depended on, from twenty to thirty cords. ${ }^{1}$ Now, it is the nitrates that start the plants of the market gardener, and, as far as the guano goes, for this end it is a wise use of it; but to develop nitrates in stable manure requires a degree of heat that the soil does not receive before the season is somewhat advanced. Without knowing it, gardeners are using this vast amount of barn manure to get a small stock of plant-food, which they have already at hand in the fertilizer market, readymade, in the form of guano and nitrate of soda. A wise head has suggested that they dispense with three-quarters of the heavy manuring, and use one-half of the value of this in investing in nitrate of soda, and put the balance in their pockets as so much money saved.

In closing the subject of nitrogen, I cannot do better than quote the able remarks of Professor Goessmann: "The air contains at all times carbonic acid, and in most instances also nitric and nitrous acid and ammonia. The scil alssorts, continually, more or less of the former, and receives the nitrogen compounds in rain and snow. Once ahsoribed by the soil, they find access to the plant by the roots, as carbonates and nitrates, where they assist in the

1 . Issuming the stable manure costs him $\$ 7$ a cord, he sares from $\$ 70$ to $\$ 120$ by using a thousand pounds of gußno. 
formation of the organic portion of the plant. Besides this direct support of plant-growth, they serve, also, the very important purpose of increasing the supply of inorganic plant-food; for they aid in the disintegration of the soil."

Sulphate of ammonia, a by-product of works where coal is used for the manufacture of gas, is one of the principal sources for nitrogen. It looks like rather coarse salt, and is marketed from barrels up to huge tierces weighing from a thousand to fifteen huncled pounds. It is readily soluble in water, but cloes not waste in the air. Nitrate of potash (saltpetre) is usually too dear a source for nitrogen to make it available. Nitrate of sodla is found in the interior of Chili, on the surface and in the soil. It is a remarkably stimulating fertilizer, and, if there is much rain, will waste before plants can take it up. Mr. Lawes advises to apply it only when not more than three feet in depth of the soil will be moistened. From one hundred to two hundred pounds per acre is excellent to give grass a start in the spring: it should not be applied before the leaf has marle a growth of three or four inches. In dry seasons it is better and cheaper than sulphate of ammonia, as the latter needs a degree of moisture to make plant-food. Still, on the whole, the sulphate of ammonia is considered the better investment: for, (1) it is not likely to be lost in the atmosphere; (2) it is not too soluble; (3) it has the power of clinging to the ingredients of the soil, clay will hold it persistently, and even pure sand, when washed with water, will retain a large portion of it; (4) its ammonia is easily changed into nitric acid hy ingredients in the soil. Nitrate of soda, we are told, "is very liable to be adulterated with white sand or broken quartz, and with salt or the cheap potash salts. ... The purchaser should see that it dissolves entirely in water, and does not taste distinctly of salt." 
I sometimes use sulphate of ammonia to hurry along crops of onions that are rather backward; spreading two hundred pounds per acre just before they begin to bottom, and working it into the soil with a slide-hoe.

Castor-Ponace is a waste from the West, being the cake left after the oil has been pressed from the castorbeans. In using it, care should be taken to keep it where animals cannot get at it. The men who spread it ought to walk with the wind; for, though not poisonous, it is a very disagreeable customer for either the eyes or mouth. It is a favorite manure for tobacco. I have used car-loads of it in former years on general crops, with good results.

Azotin, Ammonite, Tanisuge. - The first two of these are animal wastes, which have been exposed to the vapor of naphtha to extract the grease. (Of late years gluewaste, of which, in its crude state, for years I used from one to two hundred cords annually, is also so treated.) The residue is dry and brittie, and rich in ammonia, and every way superior for fertilizing purposes to the same substances before treatment. These are not usually found in the retail market, but are purchased by manufacturers of fertilizers at prices based on their per cent of nitrogen and phosphoric acid, as shown by analysis in each lot offered for sale. Job lots of from five to ten tons can sometimes be purchased of brokers, or from great slaughtering establishments like that of Armour \& Co. of Chicago. Tankage is a waste product from the intestines and other parts: it contains more or less of bone, easily crumbled, and is not uniform in fineness.

Dried Blood is the blood of the slaughter-house with most of the moisture dried from it, leaving it in good mechanical condition for handling. It is very rich in nitrogen, and is largely used by manufacturers of fertilizers. There are two grades, the light and the dark colored; 
the latter being liln-dried. Sometimes, when the heat is too great, it is partially burned, to the destruction of a portion of the ammonia. The nitrogen in blood acts very readily as plant-food.

Cotton-Seed Meal had better be first fed, as the manure from it is almost as rich in fertilizing materials as was the meal before feeding; for, as we have stated elsewhere, full-grown animals take but a small per cent of the potash, phosphoric acid, or nitrogen that exists in their food, while butter takes none. Occasionally spoilt cottonseed meal can be found in the market that is nearly as good for manure as the best of meal, and, being generally valued at about three-fifths as much, is a very cheap source for nitrogen and phosphoric acid. When spoilt by transportation by salt-water, it is generally in very hard lumps, which have to be ground in a mill. One high recommendation that castor-pomace and cotton-seed meal have, is, that their manure elements are in condition for immediate use as plant-food.

Hoof and Horn Shavrags axd Leather. - All of these are very rich in nitrogen, but it is not readily available, and therefore has a low value as a market article. Hoof and horn shavings analyze as high as 11.81 nitrogen; and, if first steamed and then ground, the nitrogen they contain becomes to a degree available. When used to adulterate superphosphate, as they very rarely are, being ground up, the particles can be readily detected by the microscope. Horn-waste is mostly in thin, bulky sharings, which are marketed in luge bags. Several years ago I purchased a ton, to test its availability and value, not having any idea of the peculiar mechanical condition of the article. Standing at my door one morning, I saw a team coming down the street with a bulk of bags piled as high as a large load of hay. While wondering what new 
product had come to town, the driver stopped, when abreast the house, and told me he had a ton of hornwaste bearing my address. I got rid of the elephant the easiest way possible, by tumbling it into the manure cellar, and throwing the daily manure upon it until it disappeared from view. My men found combs, more or less perfect, among the mass, enough to supply their fumilies for a year or more. This stuff is very rich in ammonia; but, though by layering it with horse manure it might be softened and dissolved by fermentation, yet it is so bulky that even at a low figure few farmers would care to invest in it.

\section{PHOSPHORIC ACID.}

This, the third substance in the three components of a complete fertilizer, is composed of the element phosphorus combined with the gas oxygen. The four great resources for phosphoric acid are the mineral called apatite, which contains ninety-two per cent of phosphate of lime, and is believed by some scientists to be the original source in nature from which phosphate of lime is derived; the phosphatic guanos, which are the dung of sea-fowls from which the ammonia has been washed out by the rain; the bones of all animals; and the mineral phosphate rocks, which are the remains of ancient marine animals. Mineral phosphates have within a few years been discovered to exist, in almost limitless extent, in North and South Carrolina and Georgia, usually accompanying beds of marl, either just above or just below them, and covering hundreds of square miles. They exist largely in nodules of rock, having holes or depressions on their surface filled with worthless material, which makes it necessary to wash them before grinding. That they are marine remains is evident to the eye from their composition, which includes marine shells and numberless sharks' teeth, some being in a per- 
fect state of preservation. Single teeth are sometimes found as large as a man's hand, weighing over two pounds. These nodules were carted out of fields as waste, just like any other rock, until the querying chemist touched them with his wand. The rocks are ground, and the finer portions of them, called "floats," sometimes applied directly to the soil; and when that is rich in organic matter, or when regetable matter can be added by ploughing under green crops, it has been found to do quite well without having been treated with acid. Says Professor Dabney of the North-Carolina experimental station, "On sandy soils, or soils destitute of vegetable matter, it appears to have no effect whatever; and, when tested by ammonium citrate, but an insignificant portion of the finest ground, called 'floats,' was found to be soluble." Composting in fermenting manure is recommended, to ascertain whether it cannot be dissolved in sufficient quantity to economically improve the manure. On some of the lands in Scotland it has been used with success as a paying investment without having been first treated with acid.

These mineral phosphates are the great source for phosphoric acid; for, at the rate commercial fertilizers are now used, bones could not begin to supply the demand. The soluble phosphoric acid, whether made from bones, apatite, phosphatic guanos, or the mineral phosphates of the Carolinas, have been found by careful tests to be all of equal value as plant-food; though the public, for oll acquaintance' sake, naturally prefer that made from bones. Some manufacturers of fertilizers, from haring superior facilities for collecting them, and knowing the prejuclice of the public, get the phosphoric acid that they use in their fertilizers wholly from bones. This much may be said in their favor, that, should any of the bone remain undissolved when treated with the acid, it would 
still have a vảlue of from four to six cents per pound, while in the finest ground Carolina rock it would be worth but two cents and a half. The phosphate of lime, as it exists in bones and the mineral rock, is made up of three atoms of lime to one atom of phosphoric acid. In this condition it is insoluble in water, though in bones slowly soluble in the soil; but if two of the parts could be got rid of, then the remainder, made up of one part lime combined with phosphoric acid, would be soluble in water. This is accomplished by mixing sulphuric acid and water with finely ground bone, or burnt bone, or finely ground mineral rock, when the two atoms of lime leave their home in the bone or the mineral, and, combining with the sulphuric acid, become sulphate of lime or plaster, leaving the phosphoric acid combined with but one atom of lime soluble in water. After having been thus formed, under certain conditions it sometimes takes to itself another atom of lime, and becomes what is called 'reverted,' or, in other words, has turned back again to an insoluble form. But the two-part lime combination is readily decomposed and rendered soluble when acted on by the carbonic acid present in the soil, and when so acted, being in the very fine mechanical condition that the action of the acid produced, readily dissolves in water, and becomes plant-food. There are a few terms used, in speaking of phosphate of lime in different forms, that it will be necessary for us to become familiar with. The insoluble combination of three parts lime is often called 'bone-earth phosphate.' When the two parts of lime have been removed, and the phosphoric acid has become soluble, it is often called acid phosphate, but generally superphosphate of lime, the prefix "super" being used to indicate that the lime has a proportion of phosphoric acid greater than is natural to it. The term 'soluble bone phosphate' is criticised by Bruckner as a 
misnomer' for there cannot be such a thing as 'soluble bone phosphate, for bone phosphate is always in an insoluble condition, and, when it is made soluble, it is no longer a bone phosphate." The term "available" phosphoric acid is sometimes used. This includes both the soluble and the reverted, as the latter soon becomes soluble in the soil.

\section{BONES, AND WHERE THEY COME FROM.}

The bones of land animals are composed of the following ingredients : -

Gelatine, fat, and water $\quad$. . . . . 48

Phosphate of lime, with a little magnesia . • . 46

Carbonate of lime $\quad$ • • • . • . 04

Potash and soda. $\quad . \quad \cdot \quad \cdot \quad \cdot \quad \cdot \quad \cdot 02$

The gelatine contains from three to five per cent of nitrogen, and the phosphate of lime (or bone phosphate) from eighteen to twenty-three per cent of phosphoric acid.

Bones are brought to the fertilizer market as the waste of the slaughter-houses or butcher-shops, from the plains of South America or the prairies of the WVest, or as "char," or burnt bone, that has been used principally as a purifier in the process of manufacturing sugar. This latter is sometimes counterfeited by mixing lampblack with mineral phosphates. Where they have been exposed to the action of the elements, bones are found to have lost more or less of their gelatine, and hence. are not so rich in nitrogen. The ways of preparing bone for plant-food are numerous: by one class of processes the gelatine is saved, and by the other lost. By burning bones either in closed vessels - which produces the bone-black, or "char" - or in open fires, all the animal matter, which includes the gelatine and oil, is consumed, and we have only phos- 
phate of lime remaining. To make the phosphoric acid in this fully soluble, we must treat it to sulphuric acid; though the results from burning the bones are, to rednce the particles to so fine a state as to make them more or less available without the use of acid.

\section{MAKING OUR OWN SUPERPHOSPHATE.}

Dr. Nichols, in his clear, practical "Barn-Floor Lecture," gives, in substance, the following plan: Take a plank box four feet square and one foot deep. This may be simply water-tight; but, if so, there must be no nails that the acid can reach, for it will eat them out and so make a leak: or it may be lined with lead, as the doctor directs; all soldering to be done with lead solder. The box will be large enough to take a carboy of sulphuric acid, with the necessary quantity of phosphate material and water to make about a quarter of a ton of superphosphate. If we take finely ground bone, the result, following the doctor's plan, will be a pasty mass, needing mixing with muck, or other dry material, to get it in good mechanical condition for use. If, instead of bone, we use bone-black, as he advises, we shall have, as a result, a dry mass easily handled. "To make our superphosphate," says Dr. Nichols, "a carboy of one hundred and sixty pounds of sulphuric acid or oil of vitriol (sixty-six degrees strength), three hundred and eighty pounds of bone-black, and ten gallons of water, are needed. Having first donned old clothes, and having at hand a little saleratus or some alkali, ready to rub on any spot, should, by chance, a drop of the acid spatter on our clothes or boots (for where it touches, if not immediately neutralized, it will char like fire), be sure to first pour in the water, and then the acid; next, slowly add the bone, stirring it all the while with an old hoe of but little value. There will be a great commotion, - a great boil- 
ing and frothing and foaming and throwing-off of heat with a suffocating vapor, which will make you think for a moment that you have drawn your last breath. But have courage: there have been a few millions of tons made before your day, and the men who made them yet survive. Because of the suffocating vapor, it, is well to do the work in the open air or in an open shed.

In the report of the Connecticut experimental station (1881), Professor Johnson gives two methods. That proposed by Dr. Alexander Müller, Professor Johnson thinks the one best adapted for domestic use of any of the processes involving the use of oil of vitriol: "Take one hundred pounds of ground bone, such as contains twenty to fifty per cent, more or less, of material coarser than would pass through a sieve having a one-half inch mesh, twenty-five pounds of oil of vitriol, and six quarts of water. Separate the bone by sifting into two, or, if the proportion of coarse bone is large, into three, parts ; using sieves of one-sixteenth and one-eighth inch mesh." Mix the coarser part of the bone, in a cast-iron or lead-lined vessel, with the oil of vitriol. When the bone is thoroughly wet with the strong acid, add the water, stirring and mixing well. The addition of the water to the acid develops a large amount of heat, which favor's the action. Let stand, with occasional stirring, for twenty-four hours, or until the coarser fragments of bone are quite soft; then, if three grades of bone are used, work in the next coarser bone, and let stand another day or two, until the acid has softened all the coarse bone, or has spent its action; finally, dry off the mass by mixing well with the finest bone. In carrying out this process, the quantity of oil of vitriol can be varied somewhat, - increased a few pounds if the bone has a large proportion of coarse fragments, or diminished if it is fine." 
Professor Stöckhardt, the celebrated Saxon agricultural chemist, gives the following process: "From a mixture of sifted wood or coal ashes and earth thrown upon a barn or shed floor, form a circular wall so as to enclose a pit capable of containing one hundred weight of ground bone; then make the surrounding wall of ashes so firm as not to yield by being trodden on; sift off the finer part of the bone, and set it aside; throw the coarser part into the cavity, and sprinkle it, during continued stirring, with three quarts of water, until the whole is uniformly moistened; add gradually eleven pounds of oil of vitriol of sixty-six degrees, the agitation with the shovel being continued. A brisk effervescence of the mass will ensue, which will not, however, rise above the margin of the pit if the acid is poured on in separate small quantities. After twenty-four hours, sprinkle again with three quarts of water, add the same quantity of sulphuric acid as before, with the same brisk shovelling of the mass, and leave the substances to act for another twenty-four hours upon each other. Then intermix the fine bone previously sifted off, and finally shovel the ashes and the earth of the pit into the decomposed bone, until they are all uniformly mixed together."

It will be noter, that the two last processes use half or less than half the usual quantity of acid allowed for a hundred pounds of bone. This is economy; for though, by using more acid, we add to the weight of the mass, still, all that is used over and above what is necessary to make soluble the phosphoric acid in the bone, merely increases the quantity of plaster present, at a cost of about $\$ 28$ per ton for the same, which is four times the market price. From the small quantity of acid used, I infer that it is assumed that the finest grade of bone is available for plant-food, with but little help from the sulphuric acid. 
By Dr. Nichols's method, our available phosphoric acid from bone-black will have cost us about as follows:-

380 pounds bone-black, at $\$ 22.50$ per ton, or $1 \frac{1}{8}$ cents per pound, $\$ 427$ 170 " oil of vitriol, at $1 \frac{2}{5}$ cents per pound . . . 238 S0 is water.

630

63 one-tenth deducted for waste, steam, and evaporation.

567 pounds, costing

Cost per ton for home-made phosphoric acid, where bone-

black, or "char," is used . . . . . . . 2340 Price in the market per ton . . . . . . . 3000 Cost of arailahle phosphoric acid per pound, the arerage being

17 per cent nearly . • • • • • • 007

Now, let us see what it would cost to make soluble the phosphoric acid, or, in other words, to make a superphosphate, when 100 pounds of bones are used.

52 pounds sulphuric acid, at $1 \frac{4}{10}$ cents . . . \$0 92

100 " fine bone, at $1 \frac{8}{4}$ cents • • • 175

25 "water.

177

17 loss in steam, gas, and waste.

160 pounds, costing . . . . . . . \$2 67

The superphosphate in a ton of bones would weigh $160 \times 20=3,200$ pounds; and the cost, at the same rate, would be, $\$ 2.67 \times 20=\$$ õ3.40, which would be, for a ton by weight, \$33.37. The average price at which it is sold in the market is $\$ 38$. Difference in cost between the home-made and purchased is $\$ 4.63$.

To determine the profits of this operation, we must deduct from the $\$ 4.63$ the extra freight of the acid and 
bone over the freight on a purchased ton of the superphosphate, and a certain fraction of per cent to be allowed on the breakage of carboys, which will occasionally occur in transportation; and the remainder, plus the advantage of knowing that we have the real article, will be the return for our labor. Let us next see what the home-made phosphoric acid will cost us when the mineral phosphate is used.

The phosphate rocks of South Carolina supply us with our cheapest source for soluble phosphoric acid. These are richer in phosphate of lime than the deposits of North Carolina, and require half more sulphuric acid to make their phosphoric acid soluble. The cost of soluble phosphoric acid at the present market price for material, viz., $\$ 13$ per ton for finely ground phosphate rock, and $\$ 28$ per ton for oil of vitriol, sixty-six degrees, is as follows:-

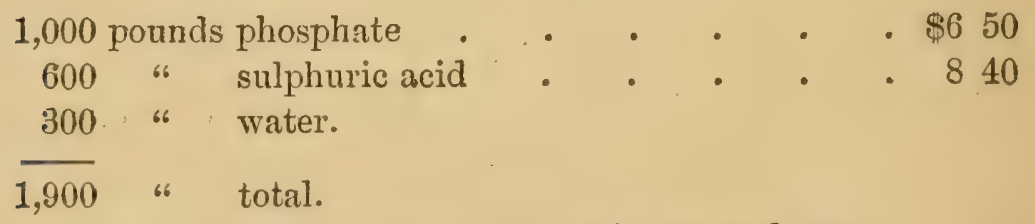

90 deducting 10 per cent for loss in gas and vapor.

1,810 pounds, costing

. $\$ 1490$

At 13 per cent, the soluble acid would be 235 pounds, costing $\$ 14.90$, or about $6 \frac{1}{3}$ cents per pound.

The phosphoric acid in finely ground bone can also be made available by the caustic action of the potash in unleached wood ashes. Dr. Nichols recommends the following method: "Take 1 barrel raw bone flour, 3 barrels dry unleached wood ashes, 90 pounds gypsum, and 10 gallons of water' make a heap of the solid materials on the barn floor, and add the water, stirring constantly with a hoe. The result is perfect plant-food, containing all the elements plants 
require in about the same proportions. Steamerl bones, burnt bones, bone-black, or char, cannot take the place of the raw ground bone; neither can any form of the German potash salts take the place of the ashes: for animal matter is needed in the bone, and potash in a caustic form in the ashes, to produce the chemical action." Says Dr. Nichols, "Five barrels of this mixture to the acre is a cheap and most effective dressing for any kind of a crop." The material used would cost, in Massachusetts, about S7.50. I would advise using the mixture in the hill, with about half the usual quantity of barn manure ploughed or harroweal in. In my own practice I incline more and more to lieep the manure near the surface, that it may have the advantage of all rains, to moisten and help dissolve the plant-food in it, for plants can take their food only when in a liquid or gaseous state. Writh this end in view, I surface manure for most crops, and work slightly under with the wheel or some other goorl harrow. Mr. Darling advises a little clifferent method and proportions: " Mix 5 barrels finely ground bone with 5 barrels of unleached hard-wood ashes; add water sufficient to moisten the mass, and then corer with loam. Leare the heap three weelis, adding a little water if it, on examination, appear's to be nearly dry." Mr. Darling, who is well acquainted with fertilizers, and might be presumed to know of what he is speaking, says that the mass will be worth fifty dollars per ton, which is at least clouble the cost of the materials that entered into the composition of the heap.

Then bones are steamed under pressure, to extract from them oil and gelatine, they are left in such a state that when ground, I have found, on using a lot of a dozen tons that had stood in heaps some months after having been steamed, apparently as good effect on crops as though they had been treated with acicl. I found, that, when used 
in hills where cabbage-seed had been planted, they soon softened into a soap-like mass. If the gelatine is taken from them, with it they lose all the nitrogen; and therefore their value as a fertilizer is to be measured solely by the phosphoric acid which they contain, and this, I think, would be classed with the form known as "invertecl." Oil or grease in any form is not plant-food, hence the loss of this is no loss to the farmer. As has been stated, bones exposed to the weather lose more or less of their nitrogen, and therefore are not so valuable for fertilizing purposes. Professor Johnson states that bone char is a little more certain as a fertilizer than finely ground phosphate rock when the latter is applied to the soil in its crude state, but it needs treating with oil of vitriol to get from it the best results.

\section{REDUCTION OF UNGROUND BONE.}

Professor Johnson, in the report of the Connecticut experiment station for 1881, gives several methods for the reduction of unground bones, from which I make the following extract: "If whole bones are treated with acid, suitably diluted, it acts energetically on the bones at first, and readily disintegrates them to a certain depth: unless, however, a large excess of acid be used, the action soon becomes sluggish, because, where the acid is in contact with the bone, it forms sulphate of lime. Fresh acid must, then, be brought in contact with the bone by abunclant stirring, in order to renew and maintain the action. The excess of sulphuric acid rapilly absorbs moisture from the air: and the final result is, the solution of the bone, or most of it, at an expense of a wasteful excess of acid ; while the product requires moisture, with something to take up the water, and neutralize the excess of sulphuric acid.

"On a small scale, cast-iron vessels could be employed. 
A pit lined with blue flag-stones, or with hard bricks closely laid in common lime mortar (not cement), would be more suitable for large quantities. After the bones are disintegrated, the sloppy mass could be dried, and its excess of sulphuric acid utilized by admixture of ground South Carolina phosphate rock or other similar material, which would thereby be converted into superphosphate."

The Russian method is as follows: "To t,000 pounds of whole bones, take 4,000 pounds (about 90 bushels) unleached hard-wood ashes, 600 pounds of fresh-burned lime, and 4,500 pounds (562 gallons) of water. First slack the lime to a powder (using part of the 4,500 pounds of water for this purpose), mix it with the ashes, and, placing a layer of bones in a suitable receptacle, - a pit in the ground, lined with boards, slab, or brick, - cover them with the mixture; lay down more bones, and cover, and repeat this until half the bones, 2,000 pounds, are inter-stratified into the ashes and lime; then pour on 3,600 ( 500 gallons) pounds of water, distributing it well, and let stand. From time to time ardd water, to keep the mass moist. As sonn as the bones have softened so they can be crushed between the fingers to a soft, soap-like mass, take the other 2,000 pounds of bone, and stratify them in another pit, with the contents of the first. When the whole is soft, shorel out to dry; and finally mix with dry muck or loam, enough to make it handle well."

Professor Johnson's method is as follows: "Arrange a circular layer of bones, closely laid, on a bed, a fout thick, of good loam, muler shelter; wet them from a wateringpot, and sprinkle them over with wool ashes, enough to fill all the chinks; then give a coat of grpsum; put upou that a few inches of muck or loam, adting, all along. as much water as will we!l moisten the earth and ashes, hut not more than the mass can readily absorb; then flace 
another layer of bones, with ashes, gypsum, loam or muck, and water, as before, until the heap is built up several feet; finally cover with loam, and keep moist by adding 'vater from time to time, but not enough to run away from the bed. When the bones are sufficiently softened, mix well together with the loam used on the bed, and cover with loam." Professor Johnson thinks this plan would require more time, but perhaps would be as efficacious, and more convenient than the process last described.

Fifteen or twenty years I tried to reduce a lot of bones by a method like this, except that some lime was used with the ashes. The results were not satisfactory; possibly the lot was kept too moist.

"A thind method suggested is by inter-stratifying them with fermenting horse-dung, and keeping the mass moist by covering with loam, and adding occasionally urine or liquor from the dung heaps."

Professor Johnson makes an estimate of the commercial value of the product made by the Russian process:-

"Four thousand pounds of average bones contain 4 per cent, or 160 pounds, of nitrogen, and 20 per cent, or 800 pounds, of phosphoric acid; 4,000 pounds of good wood ashes, unleached, contain $8 \frac{1}{2}$ per cent, or $3 \pm 0$ pounds, of potasl, and 2 per cent, or 80 pounds, of phosphoric acid. Therefore

" 160 pounds of nitrogen, worth 20 cents . SS0 pounds of phosphoric acid, worth 9 cents 380 pounds of potash, worth $5 \frac{1}{2}$ cents

$\$ 3200$

7920

1870

$\$ \overline{12990}$

"Admitting that there is no loss of nitrogen, and no loss or gain of water, and taking no account of the loam, the value of $\$ 129.90$ would belong to 13,100 pounds, or $6 \frac{1}{2}$ tons, of the finished lime compost. The cost of one ton would accordingly be, in round numbers, $\$ 20 . "$ 
The cost of the raw material would be about as follows : 4,000 pounds of bone, at $\$ 20$ per ton . . . . . $\$ 4000$ 90 bushels of unleached ashes, at 33 cents per bushel . . 3000

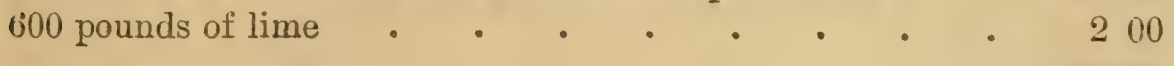
$\$ 7200$

Deducting one-tenth as waste in gases and evaporation, as $\$ 12990$ claimed by manufacturers of fertilizers

Deducting cost of raw material . . . . . 7200 We have left, to pay for our labor . . . . . $\overline{\$ 4491}$

At a meeting of the Massachusetts Horticultural Society, Mr. William Hunt made an interesting statement of his methorl of making the phosphoric acid in bones arailable. He bought the elements bone and ashes, which he used freely on grapes and strawberies, and was much pleasecl with the results. He bought from three to ten tons of bones jer year, and ashes when he could get them. He found that it did not pay to use acids to reduce bones: the same money in potash would produce better results. Last Jear he user from 1,800 to 2,000 pounds of potash, which cost $t \frac{1}{2}$ cents jer pound. It comes in casks of about four hundred pounds each, and is as hard as stone. He uses four or five parts of bone to one of potash. The bone, which is ground, but not very fine, is spread in the barn cellar. The potash is put, in large pieces, in a bag, and there broken with a sledge-hammer, and put in a tight barrel, into which was poured boiling water, and clissolved to saturation. In handling the potash, care must be taken not to get it on the cluthes or person. It is then turued on the bone, which sets up a great heat, evolving the nitrogen, to absorb which, plaster is used. It is allowed to remain two or three weeks, and is turued over several times, and 
every time covered with plaster. It is considerable trouble to reduce bones in this way, but it gives a better return for the money than buying fertilizers in the market. After the potash has acted on the bone, large pieces can be crushed in the finger's. He has used no other fertilizer than this on his strawberries, and it is equally good for grapes. He has put no animal manure on his grapes since they were set out, but either ashes or bone and potash; and this treatment has been so satisfactory that he will continue it. A neighbor has used a similar preparation of bone and potash on his pear-trees, making the fruit better and fairer. Mr. Hunt's method would be apt to rolatilize a large portion of the nitrogen from the bones by the rapid caustic action of the potash.

\section{THE THEORIES OF FERTILIZING.}

My litt'e treatise, aiming at facts, can hardly stop to discuss theories. When the able men who have spent their lives in investigating plant-feeding differ fundamentally in their views, which shall we, simple farmers, pin our faith to? Boussingault values manures in proportion to the ammonia they contain, making no account of the mineral constituents. Leibnitz bases his value on what he finds in the ash, and ignores the ammonia qualities. Ville, in his theory of manuring, advocating the use of nitrogen for wheat, potash for legumes, such as beans, pease, etc., and phosphoric acid for roots, such as turnips, parsnips, etc., considering potash - lime in some form and nitrogen as making a complete manure, advocates manuring on poor soil with a combination of all of these for the first crop, no matter what that may be, to the end that the soil may be made a fertile one; and, after the first crop, to make each year an application only of the one element which is the preponderating one in the crop 
we plant, varying the kind of crop each season, so that each element in turn will be necessary, and thus, in the course of three years, each will have been applied. I understand he holds, that, by this system of manuring, we may continue indefinitely to raise crops, using yearly not more than a single element for each.

The two theories that are especially adrocated in our day are what may be called the Stockbridge and the antiStockbridge. The professor gave a great impulse to the use of fertilizers when he laid his theory before the public. It had in it a fascinating simplicity, and seemed to present a short cut to success in farming. As tersely stated, in its most advanced form, by the company who are authorized to compound the formulas that bear his name, it is, "To feed plants those elements found by analysis to enter into their composition, and which they do not obtain from the soil or air in sufficient quantity; to feed the plant rather than the soil, and, in the feerling of the plant, to select those forms of plant-food which experience has shown are best adapted to produce perfect growth." The objections of those who do not believe in formulas for different crops are, in brief, that the formulas are not constant, having varied in the course of four years, - that for corn, from 4.7 to 6.2 for nitrogen, 3.8 to 7.2 for phosphoric acid, and 6.2 to 7 for potash; in that for the potato, from 3 to 4.4 in nitrogen, from 3.8 to 7 in phosphoric acid, and from 4.9 to 10.2 in potash; while in that for onions, the variation was from 3.1 to 3.9 in nitrogen, 5.3 to $6.4 \mathrm{in}$ phosphoric acid, and 7.9 to 8.3 in potash. In studying the tables of clifferences, it is well to bear in mind the remark of the distinguished Professor Voelcker: "Before a manure can be obtained that is specially adapted to particular soils or crops, it is necessary that enterprising and intelligent men incur heavy expense, 
in trying all kinds of fertilizing mixtures, before they can succeed in ascertaining the states of combinations, and the relative proportions in which these shall be combined, in order to produce the best practical results."

The original formulas published by Professor Stockbridge, in which his plant-food was determined solely by analyzing the plant, - as further experience has thrown light on the subject, the feeding-power of the plant having been found to be a factor of importance, - have been considerably modified. He has increased his phosphoric acid for potatoes and grass about thirty-three per cent, for corn fifty per cent, and in the two latter has decreased the nitrogen about twenty-five per cent. In pease and beans he has increased the phosphoric acid about fifty per cent, and has decreased the nitrogen: and, further, some of the finer distinctions have been dropped; and the formulas are now generalized so far as to have in several instances the same formula for several different crops, in this respect approaching to the "Ville" theory of plant-feeding. The objection that the widle latitude shown in the extremes in the nitrogen, potash, and phosphoric acid in the corn, potato, and onion formulas, elevates them in real value at present but little above a good superphosphate, has a degree of weight. To my mind, it arises from the fact that formulas, being for general use, can be compounded only in a general way, by reason of the many differences in the natural condition of various soils, the additional variations in the manurial elements which they may have acquired through years of manuring, and the difference between crops in their feeding capacity. Here, I think, we have the weakness of the Stockbridge or any other formulas. They do not take cognizance of the state of the soil to which they are to be applied; neither can they do so, except in a general way, for otherwise they would 
have to be modified to suit each particular case presented. It is true that Professor Lawes says, that, after an experience of forty years, he knows little of certainty about the soil; what he has learned is, what plants feed on. This seems to sustain the Stockbridge theory; but when he adds that he has learned, that, if he puts on an excess of phosphoric acid or potash for any crop, he gets it back in the next crop, his argument is one for the use of any good fertilizer, rather than a formula. We all expect to know more of the feeding-habits of plants, and the artificial condition and natural character of soils, as years pass on; and, as this knowledge increases, the theory will have the advantage of it, and be modified accordingly. The Stockbridge theory gives us a starting-point. If we are to wait, in all patience, until science points out a perfect way, meanwhile we stagnate.

Take the case of $\mathrm{Mr}$. Bartholomew, the results of whose soil-tests are frequently allucled to in the reports of the Connecticut experiment station. By testing his soil, he las really learned something of great value to him, though the man of science may well say, that, as a scientific experiment, it lacks lots of conditions. Now, can any one believe that Mr. Bartholomew need rest simply on the fact that phosphate is the ruling element needed in his corn-crop? Can he not, by studying the effects of combinations of fertilizers, and the modifications they receive by different crops on different soils, gradually work nearer and nearer to just the best proportion of each fertilizer to use in each combination he makes for each crop? and is not this working up to formulas? Just as England, Scotland, and the United States have each their man to thank for giving vitality to the steam-engine, entirely aside from the man who may have originated the elementary icleas, and will always hold him in remembrance, though the relation be- 
tween the original engine and the after-product may be more that of striking contrast than one of resemblance, so, I believe, we farmers ought always to feel a debt of gratitude to the professor for starting on the farm the formula system of manuring, thus insuring it it future outside of the laboratory. All manufacturers of formulas, as far as I have observed, now take into consideration what they have ascertained of the feeding-habits of plants. Now, let each farmer who uses formulas, ascertain, by actual trial, the peculiar needs of lis own soil, and modify the application of these formulas accordingly, and he will certainly have something better in his hands than the best superphosphate in the market.

\section{TESTING OUR SOILS.}

Professor Atwater was the first in this country, as far as my linowledge extends, to digest into a practical plan the idea of testing our soils to ascertain which of the three elements is especially lacking. The test is most satisfactory on poor or worn-out soils. The fertilizers with which to make these tests are put up seven in number, making a full set, which is sold for seven dollar's, - the bare cost. The sets are not sold in parts; they contain the elements singly and in combination. The quantity of each lot is sufficient for one-tenth of an acre, making fertilizing material sufficient for seven-tenths in all. 'Corn, potatoes, or any other crop, may be planted, leaving two of the plots without any manure, on the remaining tenth using the same value of barn manure. The design of these experiments is, to enable farmers to settle the question in which of the three elements, viz., nitrogen, potash, or phosphoric acid, the soil is especially deficient, and which combination of them is most needed to produce the crop. Besicles the set to settle these questions, others are put up 
to enable the farmer to determine what form of nitrogen, potash, or phosphoric acid is best adapted to his soil, or to produce any particular crop; also a set to cletermine what special fertilizer was most profitable for any special crop. These sets are supplied by the Mapes Formula and Perurian Guano Company, 158 Front Street, New York; also by the Bowker Fertilizer Company of Boston. I believe Messrs. Mapes, and probably Bowker \& Co., send out explatuatory circulars, giving full instructions how to use them. Several of our agricultural papers have been very active in encouraging this good work. I have used one of these test sets on my land with profit.

One fact may be safely inferred without a test; viz., that all old pasture-lands, when brought under cultivation, especially need phosphoric acid to give back to the soil the great draught that has been made upon it by the phosphate carried away in the milk of cows and in the bones of the young calf. I adrocate the Stockbridge theory as modified by the soil-test plan advocated by Professors Atwater and Johnson: first, to determine by actual tests what our soils lack, and then use the Stockbridge formulas, modified by the knowledge so obtained. The fundamental idea is, that, to use manures economically, we must select those which fit the wants of the special cases where they are to be applied. The old idea of the practicability of analyzing the soil to determine what plant-food it is necessary to apply, is exploded. It is found, that, if ten times the amount of plant-food for any crop is mixed with the soil, the chances are not one in ten that the chemist can detect its presence. The crop can do it far better than the chemist can. A few pounds of guano applied to an acre of land would be found by the crop, and make a difference in the yield; while Professor Johnson tells us, that, even if a thousand pounds 
were applied to an acre, the chemist might not be able to detect its presence.

\section{A FAITH THAT IS DANGEROUS. - BUYING CHEAP FERTIL- IZERS.}

There is a class of farmers who have a degree of faith in fertilizers, but regard them as a sort of "hodge-podge" combination of various ingredients sold as making things grow, which sometimes hit it, and at other times miss it, either because the maker missed his guess, or because he deliberately intended to cheat his customers. Believing, therefore, that one fertilizer is just about as likely to be as good as another, they very naturally buy the cheapest in the market, regarding the whole business as a mere lottery. The want of knowledge that lies back of this view of fertilizer's reminds me of the doings of one of my foremen some years ago. I sent him various materials for a compost heap, and also a lot of unleached ashes, guano, and hen-dung, with particular directions what to mix, and which of the various materials to keep separate. When I came, a while after, to view the state of affairs, I asked to see his manure piles. He showed me his compost heap. I then asked for the ashes, hen manure, and guano. "It's all there, boss," said he, pointing to the compost heap; "and, I tell you, it's the greatest manure heap you ever saw." I thought so, too: hen manure, guano, unleached ashes, glue-waste, rotten sea manure, tumbled together pellmell, and the free ammonia generated filling the air with its pungent fumes! I had it covered at once with dry muck, and then endeavored to enlighten him on the difference between a "hodge-podge" of material, and a compost heap intelligently put together.

I was told of an instance where last season a market gardener, a man of superior ability in some departments 
of his business, having used fertilizers in former years, believing that the more of a good thing the better, in planting his drill-crops, cut a hole in each bag of fertilizing material, when two men would walk along the rows, carrying the bag between them until it was empty. A gentleman told me, who saw his potatoes dug, that at that time the fertilizer would turn up two or three inches deep under them. This gardener used sixty or more tons in this way; and more or less of his crops, as might have been anticipated, were any thing but a success.

The words "cheup" and "cheat" are almost synonymous when applied to fertilizers offered for sale. Consider the matter a moment. Potash, nitrogen, and phosphoric acid, the three ingredients which give to them about all their value, have become regular market articles in every form in which they are found, whether in bones, fish-waste, phosphate rock, German potash salts, slaughter-house waste, cotton-seed, tankage, or in any other combination in which they come into the market. When a dealer has any of these for sale, and offers them to manufacturers of fertilizers, he (the manufacturer) takes an average sample of the lot, puts it into the hands of his chemist, who at once analyzes it, and reports what per cent of nitrogen, phosphoric acid, or potash, as may be, the article contains. 'The manufacturers purchase it on that basis; viz., so much per pound fur either ingredient: in valuing it, reference being had to the degree of availability in which they exist in the articles offered. Potash, nitrogen, and phosphoric acid being, therefore, regular market articles, how can any manufacturer undersell his fellow-dealers with a fertitizer of equal value? The whole thing is governed by the common rules of business. It can only be by using more capital, and so buying his raw materials on a larger scale, and thus getting the reduction that any man in any business gets; 
or by improverl machinery, improved processes of manu. factures; or, finally, by selling more than his fellow-clealers, and so being able to afford a smaller profit on each ton. The difference in the selling-price of fertilizers turns, then, on how much of nitrogen, potash, and phosphoric acid enter into their composition, modified by the above-named circumstances.

The analyses published by the able chemists at the head of the various agricultural colleges are the great check on frauds, and, in general, a very safe guicle to the farmer as to the richness of the various fertilizers in the market, though they do not pretend to be able to tell whether any particula: one is cheaper for him to use than barn manure, is best adapted to his soil, or to produce profitably any particular crop: this is a matter that the farmer must determine for himself. The fertilizer laws of the different States have driven most of the "cheap and cheat" class from the market. If any one is interested in knowing what these laws have accomplished for the farmer, let him read the last chapter of Brucliner's work on "American Manures," where he will find analyses of eleven fertilizers that were advertised in 1870 for an average price of $\$ 50$ per ton, the average of whose real value, aside from the insoluble phosphoric acid in their composition, proved to be but $\$ 13.70$ per ton. It is good advice to buy no fertilizer of which you have seen no analysis published in the bulletins or anmul reports of some of our agricultural colleges. There is one just now being sold in Eastern Massachusetts by a new firm which is little or nothing more than a mixture of ashes, lime, and salt.

With the best of helps, we take as much risk in our purchases as wise men should take; for the chemist does not tell us (can he?) whether our phosphoric acid was derived from bones or the mineral rock, or our nitrogen from fish or flesh, or the practically worthless leather scraps. 


\section{MAKING OUR OWN FERTILIZERS.}

There is one way by which a fertilizer can be afforcled at a price lower than the standard price of the three elements that enter into its composition; and that is, by using such local waste materials as are not accessible to dealers in general. Dead animals and surplus fish supply these material in some localities. If farmers in the vicinity of large towns would start some one in the business of working up the carcasses of horses, cows, and other animals that die from disease, accidents, or are killed because they can no longer serve their masters, they might have a cheap source for superphosphate; for in the hicles, manes and tails, oil, grease, gelatine, hoofs, and horns, the manufacturer would find sources of income which would enable him to offer the waste, in the shape of a superphosphate, at a figure below the average market rate.

Where it is necessary to have heavy machinery to grind bone or other materials, it is a question whether either the individual farmer or an association of farmers can make it a profitable investment. I know one instance where farmers associated, and, buying machinery, ground bones, treated them with acid, and so made their own superphosphate. The leader in the enterprise stated that it did not pay when they could get an honestly made phosphate at the average market price. The Cumberland Superphosphate Company, in Maine, an association of individuals who have in their employ experionced chemists, was organized, I understand, for the special purpose of supplying the members of the association with an honest superphosphate as cheaply as it could be afforded. I am told that pecuniarily this is not a successful enterprise; and any one who looks at the analysis in the Maine "Report of the Inspector of Fertilizers" will see the reason why, - they are selling: 
an over-good article. If the farmers of Maine will buy Red Beach at $\$ 45$ per ton, when the analysis shows a valuation of but $\$ 26.19$, and pass by Cumberland, which $\cdot$ sells $\$ 40.83$ worth of fertilizers for $\$ 10$, why, they are not as shrewd Yankees as they have the credit of bcing. Here naturally arises the question, why a fertilizer that by analysis is shown to be of a low grade in value, sometimes may give better returns than one of highes: cost. It is generally because it may have had more of one of the three elements than the better fertilizer, and hence may have been better adlapted for some particular crop to which it was applied; whereas the more costly one would have shown returns commensurate with its cost had it been applied to the right crop. Where bone-black, ground bone, or finely ground phosphatic rock is used, it will pay farmers to make their own superphosphate when the process of Dr. Nichols, and especially that of Professor Stöckhardt and Dr. Müller, are followed, as given on p. 61. For the past three years I have made, more or less, my own superphosphate.

\section{THE MANUFACTURERS OF FERTILIZERS.}

I have no war to wage against the manufacturers of fertilizers. The degree of dishonesty and carelessuess or ignorance of former years is now renclered impossible in many localities by State laws and the frequent.reports of the agricultural chemists. The manufacturer is a necessity that we farmers cannot do without. He brings to the business the knowledge and the capital necessary to handle the various great wastes in the most economical manner to get therefrom fertilizing materials. Most of them have one, and some of them two, chemists constantly in their employ; and one, I know, has ten thousand dollars invested in a building wholly devoted to the single department of 
repairing machinery. They have the expense of workmen, clerks, costly rents, travelling-agents, to meet (one has eleven), and allow a profit to the retail dealer. While those engaged in many occupations turn their capital several times a year, making more or less of profit every time, the sales of the manufacturer of fertilizers are limited to a few months in the year; and these are made on long time; so that, from the date they invest money in crude materials, to the time they receive pay for the same, is nearer two years than one. In the table from our experimental stations, comparing the value of the rarious fertilizers with the market price of the materials that enter into their composition, we rarely see credit giren for the bags in which they are packed. These must cost not far from a dollar and a half for each ton of fertilizers; while many rot, and have to be replaced before they leave the establishments.

From consiclerations like these, it appears but fair for us farmers to concede to the manuficturer, as but his just due, from three to five dollars per ton for his fertilizer orer the retail market price of the potash, nitrogen, and phosphoric acid that enter into its composition. Professor Dabney gives good testimony to the honesty of manufacturers when he says, that, of the six hundred samples of fertilizers analyzed in North Carolina, but one was found in which there was an attempt to defraud in the element ammonia; and that, if I remember correctly, was in an imported English superphosphate.

\section{LEATHER-TVASTE.}

This consists of the scraps of the shoe-manufactories, the waste from the upper's and soles. In many of the. establishments it is burnt as fuel, to which there is the objection that the creosote formed from it clestroys the mor- 
tar in chimneys. Owing to its richness in ammonia, and the facility with which, when steamed under pressure, it granulates into a fine blood-colored powder, or readily grinds up after being charred, it has been largely used by ignorant or unprincipled manufacturers as a source for nitrogen in their fertilizers, several of the States having, mntil recently, required by law the per cent of nitrogen, without designating in what form it should or should not be. The gelatine present, though rich in ammonia, is rendered by the tamnic acid nearly insoluble, and hence for annual crops is practically worthless. This adulteration has been carried on to a far greater extent than the public is aware. Tens of thousands of tons have been so disposed of, as I have been informed by those behind the scenes. In the Massachusetts Agricultural Report for 1882, it is stated that leather scraps were offered in Boston, early in the season, in a fine state of subdivision, at $\$ 5.50$ per ton; but later, in the month of May, they advanced to $\$ 15$ per ton. The cause of this advance, it would require no great wit to perceive. It is said that from four thousand to five thousand tons were sold in and about Boston that year, to be used in the manufacture of fertilizers. If every State would require the dealers to state the source from which their nitrogen was obtained, the adulteration would soon cease, for every chemist has at hand the means of detecting its presence. Though the process is a slow one, leather scraps, even the coarsest, from sole leather, will eventually decay; but this fact gives no value to them for the growing of annual crops, for they need to be years in a mass before they will turn black and rot. I have used tons of them around currant-bushes, where they serve to keep) down weeds, and in the course of years entirely disappear, becoming plant-food. If used into tillage-land, they become a nuisance, for more or less of 
them will keep working to the surface, where the hoe, coming in contact with their tough substance, will be bounced out of place, with the danger of cutting off the plants among which you are at work. The only other really profitable use of these scraps by farmers is for covering over blind drains, to keep the soil from sifting down among the stones or tile. I have used them in corering miles of such drains, and kniow of nothing as good, especially where the sole-leather waste is used. I have one that was male nearly thirty years ago, where the scraps-over small stones, with tile below-appear to be as useful as at the first.

\section{SOME FACTS AND SUGGESTIONS.}

In using potash or phosphoric acid in any form, we will not forget that it never wastes in the soil to any extent; and, if there is more applied than a crop needs, the next crop will find it. "Fertilizers rich in ammonia, Peruvian guano, sulphate of ammonia, etc., should be applied, a little at a time, and often." Clayey soils do not, as a mule, need so much potash or nitrogen as phosphoric acid. Nitrogen tends to promote leaf-growth. Fertilizer's applied to poor land produce more effect than when applied to rich land. In twenty-five experiments with various fertilizers, under the direction of Professor Atwater, it was found that the most important factors in the growth of the corn-crop were, first, the soil; next, the season. It was a sensible and suggestive remark of $\mathrm{Mr}_{\mathrm{r}}$. Bartholomew, that, if the bone in the soil does not all decompose the first year, the nitrogen contained in it goes orer with it - is not wasted. If but one of the commercial fertilizer's is to be used, let it be bone. The finer the bone, and the finer and dryer the fertilizer, the more valuable it is. "The most profitable fertilizers," says Professor Atwater, "are 
those that fit special cases. . . . To compost fish-waste with plaster and earth is more economical than to treat it with acil." "The soil," says Professor Ville, "is the medium in which we convert at pleasure phosphoric acid, potash, and nitrogen into any crop we choose to grow." When the animal matter in bones decays, the phosphoric acid in the bones, say our scientific teachers, is in a reverted condition. Says Professor Atwater, "The common impression among farmers, that the best use of artificial fertilizers is to supplement farm manures, is doubtless, in ordinary circumstances, correct." Both Mr. Lawes and Professor Ville are of the opinion that the largest crops are grown by chemical manures. Salt-cake (sulphate of soda) contains about forty per cent of sulphuric acid, and is an excellent material to check decomposition. Under this plea, it is used by some manufacturers with altogether too liberal a hand in their fertilizers, for of itself it is of but little value as plant-food. Nitre-cake, the refuse from the manufacture of nitric acid, contains about forty-seven per cent of sulphuric acid, and is an excellent material to scatter over manure heaps, to hold the ammonia. The difference between nitrogen in barnyard manure and in ammoniacal salts (sulphate of ammonia, etc.) was strikingly shown in some of the experiments of Mr. Lawes, where forty-one pounds of nitrogen in the latter produced as great effect on a crop of barley as did two hundred pounds in the former. Dr. Voeleker found in perfectly fresh horse-dung but one pound of free ammonia in fifteen toms, though there was nitrogen enough to supply one hundred and forty pounds of it. This suggests the wisdom of first composting, and so decomposing and making it soluble, when we want prompt effects. Barnyard manures decompose faster in porous (sandly or gravelly) soils than in compact ones. Says Professor Goessmann, "Good 
manuring increases the quality as well as the quantity of our crops. . . Besicles salt-cake (as mentioned above), nitre-cake, ground oyster-shells, spent lime, plaster, and soil are mixed with ground bone as preservatives, dryers, or adulterants."

In purchasing our elements out of which to make fertilizers, their degree of fineness or dryness has an important bearing on their value. Says Professor Goessmann, "The mechanical condition of any fertilizing material, simple or compound, deserves the most serious consideration of farmers, when articles of a similar chemical character are offered for their choice. The degree of pulverization controls, almost without exception, under similar conditions, the rate of solubility, and the more or less rapid diffusion of the different articles of plant-food throughout the soil. The stute of moisture exerts a no less important influence on the pecuniary ralue in case of one and the same lind of substance. Two samples of fish fertilizers, although equally pure, may differ from fifty to a humdred per cent in commercial value, on account of mere difference in moisture. If obliged to increase our home resources of manure, he advises to compound fertilizers from the most suitable stock in the market. Although a first trial of that course of action may not realize all the advantages expected, there can be no doubt about the correctness of the statement, that the best financial success on the part of the farmer can ultimately be secured only by the gradual adoption of that system of manuring the farm. Our leading dealers in fertilizers begin to realize the late tendency in their trade, and are preparing to meet the call." 
COMMERCIAL RETAIL VALUES OF FERTILIZING INGREDIENTS IN RAW MATERIALS AND CHEMICALS.

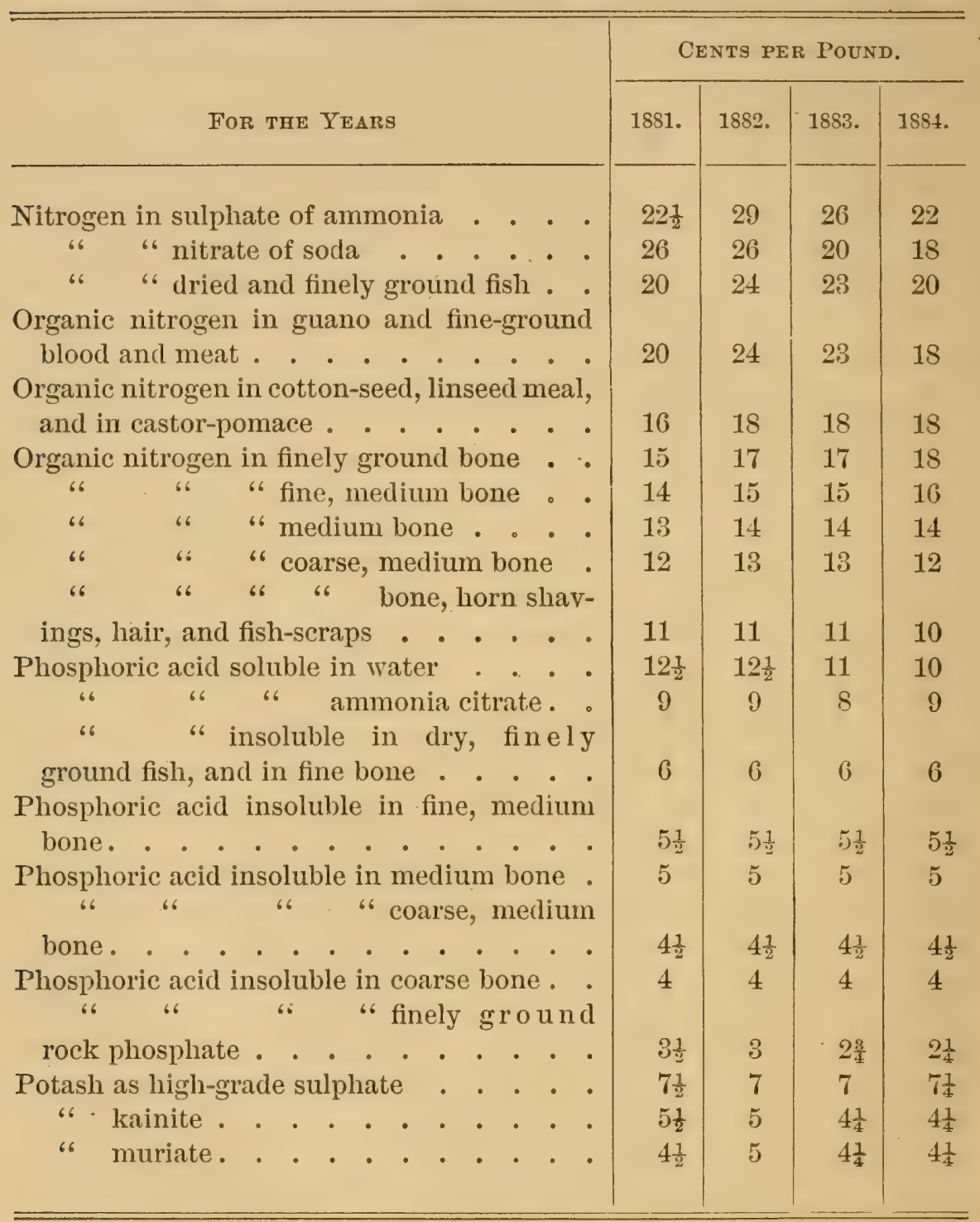

The wholesale rates average about twenty per cent higher than the retail rates of this table. As a rule, fertilizing materials are cheapest in the fall and winter. At the time 
of writing (spring of 1885), nitrogen in some forms is somewhat higher than last season.

The word "organic" in the above table may be practically ignored by us farmers when figuring on these fertilizers. The table is an estimate of relative commercial values agreed upon by the chemists and directors of the experimental stations of Massachusetts, Connecticut, and New Jersey. In point of fact, competition forced prices below these rates, as will be noted in the following table, which gives the prices at which the nitrogen, phosphoric acid, and potash were sold in $188 \pm$ by leading dealers in various combinations :-

Average cost per pound of nitrogen in nitrote of sodar

Cents.

" " " " " 6 in sulphate of ammonia • 17.1

" " " " " " " 6 in dried blood .. . . 18.3

" " " " " " 6 in ammonite and tankage . 15.8

" " " " " $"$ " in dried fish . . . 12.5

" " " " " " " $"$ " in castor-pomace . . 20.2

" " " " " " in hair manure . . 10.3

Average cost of phosphoric acid from bone-black, soluble in water, 7.3 cents; insoluble, 2.9 cents.

Arerage cost of soluble phosphoric acid from South Carolina rock, 8.6 cents; insoluble, 1.9 cents.

Cents.

Average cost of potash per pound in muriate • • • 3.7

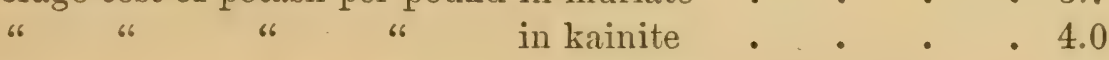

" " " " 6 in sulphate . . . 7.2

The above are the retail prices, delivered on cars or boats.

Professor Cook of the New Jersey experimental station, from which valuable report the above table was taken, states that the samples analyzed by the station in 188t, in five cases out of six contained more plant-food than their minimum guaranties demanded: they were better than the manufacturers claimed. 
COMMERCIAL AND AGRICULTULRAL VALUES OF FERTILIZERS.

The prices in the above tables are the market or commercial value of the three elements. Says Professor Cook, "The agricultrural value of a fertilizer - in other words, the profit which its use secures for a farmer in an increased crop - is in no way indicated by its market price. Reliable information concerning agricultural values must be sought upon the farm, and not by the guesses of the farmer, but from the actual weight of the crops grown under known conditions, and upon accurately measured areas." Hot or cold, wet or dry, seasons, will affect the results obtained from fertilizers, but cannot be said to affect their agricultural value; in fact, the results of numerous experiments demonstrate that these extremes have a greater effect on crops fed on barn manure than on those fed by fertilizers.

WHERE TO OBTAIN OUR FERTILIZING MATERIAL AT THE LOWEST COST.

The table directs us for what substances to inquire when we go into the general market. But there are outside sources which are more or less accessible to the average farmer. Even in the varied products of the farm, the three elements vary greatly in cost.

Professor George Caldwell makes the following estimates of the value of nitrogen, potash, and phosphoric acid in various combinations. Assuming that in 1884 potash could be purchased at 5 cents per pound, phosphoric acid at 9, and nitrogen at from 16 to 18 cents, then, at these rates, - 


\begin{tabular}{|c|c|c|c|}
\hline & $\begin{array}{l}\text { Cost of } \\
\text { Nitrogen } \\
\text { per Lb. }\end{array}$ & $\begin{array}{l}\text { Cost of } \\
\text { Potash. }\end{array}$ & $\begin{array}{l}\text { Cost of } \\
\text { Phos. } \\
\text { phoric } \\
\text { Acid. }\end{array}$ \\
\hline & Cents. & Cents. & Cents. \\
\hline $\begin{array}{l}\text { In cow manure, at } \$ 1.16 \text { per thousand pounds } \\
\text { (about } \$ 7 \text { per cord) }\end{array}$ & 19 & 6 & 11 \\
\hline $\begin{array}{l}\text { In horse manure, at } \$ 1.54 \text { per thousand } \\
\text { pounds (about } \$ 6.90 \text { per cord) } . \cdot \dot{*}^{-} \cdot \text {. } \\
\text { In rock-weed, at } \$ 1.21 \text { per thousand pounds }\end{array}$ & 14 & $4 \frac{1}{2}$ & $7 \frac{9}{10}$ \\
\hline (about $\$ 4.25$ per cord)....... & $20 \frac{1}{2}$ & $6 \frac{9}{10}$ & $6 \frac{3}{10}$ \\
\hline 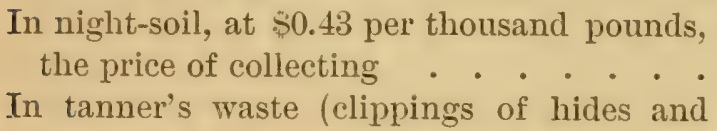 & $2 \frac{8}{10}$ & 1 & $1 \frac{6}{10}$ \\
\hline hair), at $\$ 0.78$ per thousand pounds. . . & 1 & - & $\frac{1}{2}$ \\
\hline In hen manure, at $\$ 4$ per thousand pounds, & 27 & $8 \frac{4}{10}$ & 15 \\
\hline
\end{tabular}

The tanner's waste would decompose slowly, and therefore its components would practically be of less value than in the other manures named. At 43 cents per thousand pounds, night-soil would cost about $\$ 2.50$ per cord. As average night-soil is worth about $\$ 6$ per cord, the professor evidently means a purer article than we farmers usually fincl. Most farmers will be surprised at the low value given lien manure in the table, but it requires a pretty good article to reach even that valuation. Hold fast to the funclamental principle, that no more value in potash, phosphoric acid, and nitrogen can come from the mamre of any animal than is fed to it in its food, minus the quantity of these elements taken up to maintain its vitality, and perfor'n its rarious functions, which in fowls includes the eggs laid and the ammual growth of feather's. And next consicler the fact that two bushels of corn will support an arerage fowl a year, and that this grain contains about 38 cents in value of the three elements; and, finally, that of this, but about half can be found in the manure, of 
which but about half can be saved, making a little over a quarter of the 38 cents in the manure saved from a fowl annually. Where we are so situated that we can go outside the general market for our fertilizing elements, we can sometimes pick them up at a very low figure. The present season (1885) I have purchased fish-waste in the form of liver, halibut, and herring chum at a very low figure at Gloucester, Mass. I have purchased the liver chum at $\$ 4$ per ton, which would make the nitrogen in it come to about $4 \frac{1}{2}$ cents per pound, and the phosphoric acid at about $1 \frac{1}{1}$ cents. Halibut chum is now worth $\$ 8$ per ton, which would bring the nitrogen in that form about 8 cents per pound, and the phosphoric acid $2 \frac{1}{2}$ cents per pound. Fish-skins, by which I mean the skins, bones, and fins stripped from fish, which are sold under the name of "boneless fish," are sold this season in Gloucester at the low figure of $\$ 4$ per ton. I have not an analysis at hand; but they are very rich in both ammonia and phosphoric acid, having about 4.50 of the former, and 6 of the latter. They are very salt, being stripped from salted fish. In this form the ammonia cannot cost over 6 cents, or the phosphoric acid over 2 cents, per pound. "Chum," or pomace, from waste mackerel or herring, is sold the present season as low as $\$ 6.50$ per ton. There is usually a large per cent of salt in its composition. The ammonia at these rates cannot be over 6 cents, and the phosphoric acid over $2 \frac{3}{4}$ cents, per pound.

I would have my farmer friends understand that the above rates are lower than usual, _ about, on an average, from a third to a half the usual price; still, at the usual prices of material, fish-waste is the cheapest source for nitrogen.

Says Professor Goessmann, "Manufacturers put it in a better mechanical condition, and sell it at about $\$ 34$ per 
toin, or an advance of from two hundred to four hundred per cent." In these forms, about all the ammonia may be assumed to be available the same season they are used, and from one-half to two-thirds of the phosphorie acid. As these fish-wastes are usually heavily charged with salt (used when fresh, to keep them), it is the best plan to use them on salt-loving crops, as cabbage, onions, and mangelwurzels. They can either be spread on the surface in the fall, harrowed in, or slightly ploughed under, or be composted in the spring with barn manure into which enters a good proportion of horse manure. Be sure to cover the heap, especially the top, with dry earth and plaster. These wastes are usuaily bought up by manufacturers of fertilizers; and the surplus to be found in the market, accessible to farmers, is never very large. I have used them for many years somewhat extensirely, having fifty tons of them at the present time, mostly composted with barn manure and rock-weed.

As my treatise is for the benefit of my fellow-farmers, I will give the addresses of parties who deal in these and other fertilizing materials at first hand; though it may not be the wisest thing for me to clo, viewed from a pecuniary stand-point, as it will tend to send me to a dearer market.

Dealer in liver, herring, and mackerel chum, Charles Tarr; dealer in fish-skins, Fred L. Stacey; dealers in halibut chum, A. W. Dodd \& Co., - all of Gloucester, Mass.

Dealers in unleached Canada ashes, Messrs. Munroe, Judson, \& Stroup, Oswego, N.Y.

Dealers in ammonite, M. L. Shoemaker (he has two grades), Philadelphia, Penn.

Dealers in tankage, John Taylor \& Co., Trenton, N.J.; Armour \& Co., Chicago (in ten-ton loads).

The list might be indefinitely extended, but I give the 
addresses of those who deal in fertilizing material not often found by farmers in the market. The reports from the various agricultural experimental stations contain the addresses of almost numberless manufacturers and dealers in superphosphates, potash, and ammonia.

\section{FORMULAS, AND HOW TO COMPOUND THEM.}

From what I have written, my farmer friends will see that I do not present the formulas I have used as the best guide for them to follow. Their soil, in its natural or artificial condition, may differ from my own; and so these formulas would require modification accordingly. In my own practice, perhaps, all these may be improved; while I know the one for beans and pease can be: and I expect to find, from some indications, I can clispense with more or less of the potash on most of my land.

It will be noticed that they are all what are known as "complete" manures; that is, each has all three of the essential elements of plant-food. It is quite possille, that, on land that has been manured for a series of rears, especially if by stable manure, the potash probably, and the phosphoric acid possibly, may be in excess of the needs of crops, and therefore can for a while be omitted from formulas; but in such case we need to be on the watcli to detect when the limit is reached, and govern ourselves accordingly, bearing in mind that the quantity of crop is always measured by the element of which the soil has the smallest quantity, and that a large quantity of one element will not help the crop over a deficiency in either of the others. This is the reason why, when, for instance, fish is used liberally, a manure especially rich in nitrogen, for a while there are enormous crops; but they sonn grow less, even under a heavier application. The trouble is, the potash of the land has been exhausted. That this is the 
trouble can be proved by using manures rich in potash, when fertility will return. My farms, four of them, are made up of land ranging from sandy loam to strong loam and reclaimed meadow. They have been under cultivation from one to ten years. During the first five years they were dressed with various manures, and more or less with commercial fertilizers; during the last five years I have depended more and more on commercial fertilizers, using, of the three ingredients which compose these, from thirty-five to forty-five tons annually. Much of this I have used in comnection with barnyard manure, using the latter broadcast, and the fertilizer in the drills. I say drills, for I have not planted corn, beans, or potatoes in hills for the past clozen year's; neither do I believe that any of my farmer friends, after once giving the drill system a fair trial, will ever go back to the old way.

\section{FORMULAS FOR VARIOUS CROPS.}

The following table of formulas for various crops are such as are used by fertilizer dealers of good repute. I present them as good starting-points, to be followed or raried as the characteristics of each field, as developed by the soil-tests, may indicate. The figures in the first three columns indicate the per cent of ammonia, etc., needed. In the next they indicate how many pounds of the mixture to apply. 


\begin{tabular}{|c|c|c|c|c|c|c|c|c|c|c|c|c|}
\hline & & & & & & & & & $\begin{array}{c}\text { Ammonia, } \\
\text { per cent }\end{array}$ & $\begin{array}{c}\text { Potash, } \\
\text { per cent. }\end{array}$ & $\begin{array}{l}\text { Phos- } \\
\text { phoric } \\
\text { Acid, } \\
\text { per cent. }\end{array}$ & Lbs. \\
\hline Potatoes & . & • & . & • & - & - & . & . & 6 & S & 5 & 500 to 1,000 \\
\hline Corn . . & - & - & . & - & - & - & . & . & $2 \frac{1}{2}$ & 6 & 7 & $600^{6} 1,000$ \\
\hline Cabbage a & nd & $\mathrm{ca}$ & ulif & flow & rer & - & . & . & 6 & 7 & 5 & $750^{6} 1,500$ \\
\hline Squash . & . & . & . & . & - & - & . & - & 6 & 7 & 5 & 1,000 ' 1,500 \\
\hline Tomatoes & - & - & - & - & - & - & - & - & 6 & 7 & 5 & $750^{\prime \prime} 1,000$ \\
\hline Fruit and & fru & nit- & bea & arin & & vine & & . & $2 \frac{1}{2}$ & 11 & 8 & 600 \\
\hline Oats. & - & - & - & - & - & - & - & . & 5 & 9 & 5 & $400^{66} \quad 600$ \\
\hline Rye . . & - & - & - & - & . & . & . & & 5 & 9 & 5 & $400^{66} \quad 600$ \\
\hline Strawberri & & - & - & - & - & - & - & - & $3 \frac{1}{2}$ & S & 6 & $600^{66} 800$ \\
\hline Raspberrie & & - & . & - & - & - & . & - & $3 \frac{1}{2}$ & 8 & 6 & $600^{66} 800$ \\
\hline Asparagus & & - & - & - & - & - & - & - & 5 & 9 & 6 & $500^{6} 700$ \\
\hline Wheat . & . & - & - & - & . & . & - & - & 6 & 3 & $7 \frac{1}{2}$ & $200^{66} \quad 600$ \\
\hline Barley . & - & - & - & - & - & - & - & - & 6 & 3 & $7 \frac{1}{2}$ & $200^{66} \quad 600$ \\
\hline Grass . & - & - & . & - & - & . & - & - & 6 & 7 & 5 & $400^{66} \quad 700$ \\
\hline Melon . & - & - & - & - & - & - & - & . & 6 & 7 & 5 & $1,000^{\prime \prime} 1,600$ \\
\hline Tobacco & - & - & - & - & - & - & - & - & $5 \frac{1}{2}$ & S & 4 & $1,000^{6} 2,000$ \\
\hline Onion . & - & - & - & - & - & - & - & - & 5 & 9 & 5 & $800^{6} 2,000$ \\
\hline Cucumber & - & - & - & - & - & - & - & - & $5 \frac{8}{4}$ & 7 & 5 & $1,200^{6} 1,600$ \\
\hline Turnips & - & - & . & - & . & - & - & 。 & 5 & 8 & 7 & $400^{6} 600$ \\
\hline Carrot . & - & - & - & • & - & . & . & & 7 & 9 & 5 & $650^{\text {‘6 }} 900$ \\
\hline Beet . . & . & - & - & - & - & . & - & & 7 & 9 & 5 & $400^{6} 800$ \\
\hline Celery . & - & . & - & - & . & . & - & $\bullet$ & 7 & 9 & 5 & $1,000^{\prime \prime} 1,400$ \\
\hline Lettuce. & - & - & - & . & - & - & • & 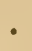 & 7 & 9 & 5 & $1,000^{\prime \prime} 1,400$ \\
\hline Pease and & bes & ans & & - & . & . & . & & 2 & $7 \frac{1}{2}$ & 8 & 500 “ 800 \\
\hline Cotton . & - & . & - & - & - & - & - & & $2 \frac{1}{2}$ & 4 & $7 \frac{1}{2}$ & 300 \\
\hline Hops . & - & - & - & - & - & - & • & & $3 \frac{1}{4}$ & 13 & 5 & 1,000 \\
\hline Sugar-cane & & - & - & - & - & - & & • & $2 \frac{1}{2}$ & $7 \frac{1}{2}$ & 8 & 800 \\
\hline
\end{tabular}

In these formulas, all the phosphoric acid is to be available; that is, either soluble or reverted, and mostly of the former. It will be noticed that all these formulas are complete fertilizers; that is, contain all of the three essential elements of plant-food. Let me again enjoin on my fellow-farmer's, when using a portion of them in the clrill, 
in order to prevent destroying the seed, to mix thoroughly with the soil before planting; using the top of a cedar-tree to which a stone has been tierl, dragging it along through the furrow, or a brush barn-broom, or even a hoe if carefully dragged. With extra care in mixing for crops such as corn, the whole of the fertilizer might be used in the furrows or hill; but no good farmer would, as a rule, raise his crop in that way. With potatoes, fertilizers are sometimes successfully applied by first covering the potato with an inch of earth, and then sowing it, finishing by covering the seed to the usual depth. A portion can be applied to the corn-crop after it is up; but in such cases it must be cultivated under, or the plant will get but little benefit from it.

In using these formulas, if you live near a good market, your regetable crop will bring more than it otherwise would; while your land, and probably your labor-bill, will be higher than it would be back in the country, and the cost of the fertilizer will be as cheap or cheaper. Such being the case, it would be wise to use the larger quantity named, and to experiment a little to ascertain whether or not, under your exceptional circumstances, it might not pay you even to increase this. Fertilizers, as has been said, do not respond so well on soil that has been heavily enriched with barn and other manures for a series of years. On very rich truck-farms, some fertilizers, even when liberally applied, have but little effect. In such cases the ground is already heavily stocked with the surplus left over by many manuring's, and will sometimes yield full crops without help from any manure whatever; but usually nitrate of soda, sulphate of ammonia, guano, or bone will give good paying returus, even on such soil. I have made use of the above formulas, with excellent results, on crops of potatoes, corn, pease, beans, tomatoes, cucumbers, 
melon, squash, onions, oats, grass, beet, and Hungarian millet.

\section{HOW TO COMPOUND OUR OWN FORMULAS.}

To start with, we will aim to get our three elements from more than one source, believing that the greater the variety from which they are obtained, the better it will be for the varied and varying wants of the crop. In making up my formulas, I start with some one fertilizer, and then add to it, from various sources, what I need to complete it. To illustrate, let us take the first on the list, that for potatoes.

The potato formula calls for: ammonia, 6 per cent; potash, 8 per cent; phosphoric acid, 8 per cent; quantity required, 1,000 pounds. That is, of this 1,000 pounds, 6 per cent, which is $1,000 \times .06$, must be ammonia, $=60$ pounds ; 8 per cent potash, that is, $1,000 \times .08,=80$ pounds; and 8 per cent phosphoric acid, $=1,000 \times .08,=80$ pounds. The formula would stand thus:-

$\begin{array}{lccc} & \text { Ammonia. } & \text { Potash. } & \text { Phosphoric acid. } \\ \text { Wanted : } & 60 \text { pounds. } & 80 \text { pounds. } & 80 \text { pounds. }\end{array}$

Let us start with a superphosphate, which we will assume to analyze as follows: Ammonia, 3.50 ; available phosphoric acid, 11. From this we will supply the phosphoric acid needed in the formula, which, as there are 11 pounds in every hundred, will require as many. hundred pounds as 11 is contained in 80 , which will be 7 hundred, and $\frac{3}{1} \overline{1}$, which would be just about 27 pounds more, making 727 pounds in all. Now, in taking these 727 pounds of the phosphate, as each hundred has, besides the phosplioric acid, $33_{2}^{1}$ pounds of ammonia, we have at the same time $3 \frac{1}{2}$ per cent of 727 pounds of this element, $=25$ pounds: we have thus obtained all the phosphoric acid needed in our formula, and $(60-25=35)$ all but 35 pounds of the 
ammonia. As the ammonia in the phosphate was doubtless from bone, let us get the remainder from sulphate of ammonia, which is a form in which it will act more promptly, and start the crop, while that from bone will feed it later in the season. Now, sulphate of ammonia contains 25 per cent pure ammonia: therefore we get our remainder of ammonia in about $\frac{35}{25}$ of a hundred pounds, $=1.40$ pounds of sulphate of ammonia. Passing next to the potash needed, viz., 80 pounds, let us get part of it in muriate of potash, and part from wood ashes, where the potash is the carbonate of putash. 80 per cent of muriate of potash contains just above 50 per cent (50.40) of pure potash. Taking a hundred pounds of this, and we have remaining, to be got from unleached ashes, $88-\check{5} 0,=38$ pounds. Now, a hundred pounds of unleached wood ashes, containing about 7 per ceut of carbonate of potash, would contain about $\frac{3}{5}$ as much of pure potash. $\frac{3}{5}$ of $7=$ $4 \frac{1}{5}$ pounds; $38 \div 4 \frac{1}{5}=9 \frac{1}{2}$ hundred pounds nearly. As unleached wood ashes weigh about to pounds to the bushel, in $9 \frac{1}{2}$ limndred pounds there would be about 21 bushels. Now, using these ashes, we have also brought with them some phosphoric acil, for wood ashes muleached has about two per cent of it; therefore in our 21 bushels we should have $21 \times 2=42$ pounds. Let us take array sufficient of the bone to allow for the $t^{2}$ pounds. As the bone has 11 per cent, we will drop as many humdred pounds as 11 is contained in $42,=4$ nearly. But, in dropling these 450 pounds of bone, we, of course, drop also the ammonia contained in it, which would be $t_{2}^{1} \times 3 \frac{1}{2}$, $=16$ pounds nearly. To get this 16 pounds of ammonia, we will take some dried blood, which analyzes 13 per cent ammonia. It would require $\frac{16}{1} \frac{6}{3}$ of 100 pounds of this, = 183 pounds nearly. Now, bringing all the sources together, and we have 
Acid phosphate . . . $727-450=277$

Sulphate of ammonia • • • • • • 88

Unleached wood ashes . • • • • • . 950

Dried blood . • • • • • . . . 133

1,448

We have for our formula, which called for 1,000 pounds of a fertilizer containing ammonia, 6 per cent, potash, 8 per cent, and phosphoric acid, 8 per cent, a compound containing 1,448 pounds. I know that the question will at once occur to my farmer friends, How can this be correct, as only 1,000 pounds were called for? True, but that was to be of a given strength, while the elements in this will not average as rich as the elements in that, and therefore more bulk is required. If, instead of taking the ashes, we had taken our entire supply of potash from the muriate, then the result would have been a compound weighing less than 1,000 pounds, for the reason that the average of the materials would have been richer. This illustration, which I have purposely made to cover about all possible variations, covers the whole matter of compounding our own formulas. What we now need to ascertain is, where we can get our own raw materials the cheapest. The various facts presented in other portions of this treatise, especially under the heads of "Potash," "Nitrogen," and "Phosphoric Acid," with the tables to be found on pp. 111 and 112, will inform us from what source to obtain the cheapest materials needed to compound these or any other formulas.

\section{SOME FOIMULAS AS COMPOUNDED.}

I herewith present the way I have compounded several formulas for my own use, not as the wisest course in the selection of material, but as suggestive in the variety of 
substances from which the three elements are obtained. The per cent of ammonia, potash, and phosphoric acid is the same for each variety of regetable as those given in the table on p. 92. The quantity applied has, in each case, the larger amount. The "Ames bone" is an honest superphosphate made by a reliable neighbor, A. L. Ames of Peabody, Mass. I will here say, that, while on old land, I have had excellent results from the potato fertilizer four years in succession, raising crops that averaged, with different years, from 200 to 317 bushels per acre in fields containing eight acres. On pasture land broken up for the first time, the results have not been so satisfactory.

\section{FORMULAS OF FERTILTZERS.}

Pease for One Acre. (Half harrowed in, Half in Drill.)

600 lbs. Ames bone.

250 lbs. muriate of potash.

40 lbs. dried blood.

\section{Potatoes for One Acre.}

500 lbs. Ames bone, in drill.

50 " sulphate ammonia, in drill.

$200 \mathrm{lbs}$. muriate of potash, in drill. guano, in drill.

Vegetable Vines for One Acre. (Three-fourths harrowed in, One-fourth in Drill.)

600 lbs. Ames bone.

100 " sulphate ammonia.

200 lbs. muriate of potash.
100 lbs. dried blood.

200 "c cotton-seed meal.

\section{Carrots or Beets for ONe ACre.}

(Harrowed in.)

400 lbs. Ames bone.

100 " sulphate ammonia.
100 lbs. dried blood.

200 " cotton-seed meal.

160 lbs. muriate of potash. 
Beans for One Acre. (Half harrowed in, Half in Drill.)

550 lbs. Ames bone.

33 lbs. sulphate ammonia.

110 lbs. muriate of potash.

Hungarian for One ACre.

(Harrowed in.)

400 lbs. Ames bone.

150 lbs. muriate of potash.

$50 \mathrm{lbs}$. sulphate of ammonia.

CORN FOR ONE ACRE.

(Half harrowed in, Half in Drill).

600 lbs. Ames bone.

\begin{tabular}{l|ll}
200 " cotton-seed meal. & 180 " muriate of potash.
\end{tabular}

Grass for One Acre.

(Harrowed in.)

400 lbs. Ames bone.

100 " dried blood.

150 lbs. muriate of potash.

100 " sulphate of ammonia.

OnIONS FOR ONE ACRE.

(Raked in before Ploughing.)

700 lbs. Ames bone.

100 " dried blood.

400 " cotton-seed meal.

$200 \mathrm{lbs}$. muriate of potash. * 250 " sulphate ammonia, or 300 guano.

OAts for One ACre.

(Harrowed in.)

300 lbs. Ames bone.

150 " dried blood.

25 " sulphate of ammonia.
35 bushels unleached hard-wood ashes.

CONDENSATION OF SPECIAL AND OTHER FORMILLAS.

Professor George H. Cook, of the New Jersey experimental station, gives five formulas, which contain the three elements in about the same proportion as they were found by analysis to exist in seventy-two different brands of fertilizer's, of which thirty-six were sold specially for various crops, such as potatoes, corn, buckwheat, etc. In

* To slide in when they begin to bottom. 
calculating the proportions of crude materials to use in making up a ton of fertilizer by either of these formulas, it was assumed that -

Sulphate of soda contains

Nitrate of soda contains

Blood and ammonite contain 1

Bone-black superphosphate contains

Acid phosphate from South

Carolina rock contains

Muriate of potash contains

Kainite contains
20 per cent of nitrogen.

16 "6 "6 "6

12 "6 6 6 6

16 " " " available phosphoric acid.

$\begin{array}{lllllll}12 & 66 & 66 & 66 & 6 & 6 & 6\end{array}$

50 " " " " " " potash.

12 6 6 "6 6

No difficulty will be experienced, says the professor, in securing supplies of these guaranteed to contain the above percentages of plant-food.

CLAss No. 1. - This is a small class, containing three brands, and includes all of the fertilizers in which the guaranteed nitrogen does not exceed one per cent.

Class No. 2. - This is a large class, containing twentyfour different fertilizers, of which sixteen are intended for general use, and eight are specially designed for fruit, tobacco, potatoes, lawn-dressing, hops, and buckwheat.

Cuass No. 3. - This class includes eighteen different fertilizers, of which eleven are for general use, and severi are specially designed for sorghum, potatoes, ete.

Cudss No. 4. - This class includes twenty-one different fertilizers, of which five are for general use, and sixteen are specially designed for grain, tobacco, potatoes, and vegetables in general.

Cldss No. 5. - This contains six fertilizers, of which five are for special crops, - tobacco, lawn-dressing, grain, and vegetables.

The value of the plant-food in an ummixed condition, given in each formula, was calculated by using the manufacturers' average retail prices for 1884 . 
Class No. 1.

To make One Ton when mixed together.

Containing Lbs, of

Blood . . . . . . 110 lbs. Nitrogen . 13.2, or $0.66 \%$ of ton.

South Carolina rock (treated

with acid) . . . . 1,600" Phos. acid, 192.0," "9.60\% " "

Kainite . . . . . 250 " Potash . $30.0, " 1.50 \%$ "

Total . . . . . $1,960 \mathrm{lbs}$.

Cost of materials unmixed . . . $\$ 19.36$.

ClASS No. 2.

To make One Ton when mixed together.

Containing Lbs. of

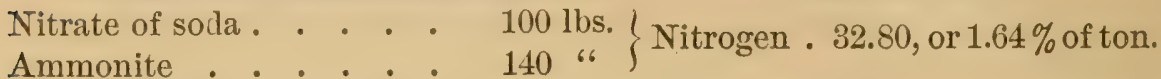

South Carolina rock (treated

with acid) . . . . . 1,400 " Phos. acid, 168.00, "8.40\% "

$\left.\begin{array}{l}\text { Muriate of potash . . . . } 50 \text { " } 5 \\ \text { Kainite . . . . . } 300 \text { " }\end{array}\right\}$ Potash . 61.00, "3.05\% "

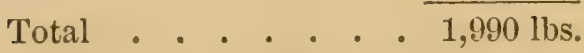

Cost of materials unmixed . . . . $\$ 21.49$.

Cluass No. 3.

To make One Ton when mixed together.

Containing Lbs. of

Sulphate of ammonia . . $50 \mathrm{lbs}$.

Nitrate of soda . . . . 100 " Nitrogen . 47.0, or $2.35 \%$ of ton.

High-grade blood . . •

South Carolina rock (treated

with acid) . . . . . 1,450 " Phos. acid, 174.0, "8.70\% "

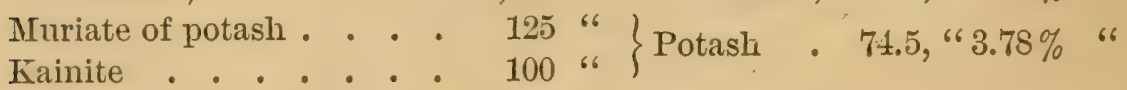

Total . . . . $\frac{1}{2,000 \mathrm{lbs} .}$

Cost of materials unmixed . . . $\$ 25.31$.

Class No. 4.

To make One Ton when mixed together. Containing Lbs. of Sulphate of ammonia . . $100 \mathrm{lbs}$.

Nitrate of soda * . . . 100 " " Nitrogen . 72.00 , or $3.60 \%$ of ton.

High-grade blood . . . .

Bone-black superphosphate. $\quad 940$ " Phos. acid, 150.00, "7.50\% "

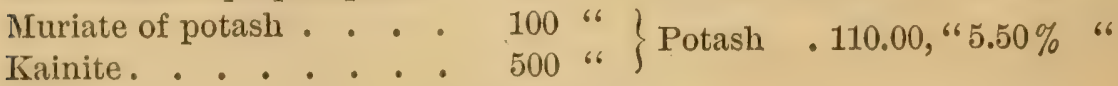

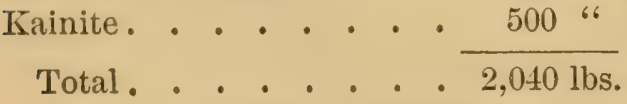

Cost of materials unmixed . . . \$27.46. 
Class No. 5.

To make One Ton when mixed together.

Containing Lbs. of

Sulphate of ammonia. . .

Nitrate of soda . . . .

High-grade blood . . .

Bone-black superphosphate.

Muriate of potash . . .

Kainite.

Total .
$150 \mathrm{lbs}$.

200 " Nitrogen, 104.00 , or $5.20 \%$ of ton.

350 "

875 " Phos. acid, $140.00, " 7.00 \%$ "

350 " 3 " 3 " Potash . $80.00, " 4.00 \%$ "

$2,000 \mathrm{lbs}$.

Cost of materials unmixed . . . $\$ 31.06$.

HOW TO IIIX THE INGREDIENTS THAT ENTER INTO A FORMULA.

Now let us try our hand at mixing together the ingredients that enter into a formula. As a base from which to start, I have taken a local superphosphate made honestly by Mr. A. L. Ames of Peabody, Mass., and have added to this, plant-food from various sources. In mixing the various ingredients together, you will need a sieve as fine again as a common coal-sieve. Haring cleared a place upon the barn floor, and having decided upon quantities of each element needed, first weigh these out, and have them near at hand; next, sift each lot that needs sifting, by itself separately, breaking up with your feet or the back of the shorel all lumps that will not pass through the sieve. Now begin with the element you need most of, and sift a portion of it evenly over a circle of sufficient width so that the first layer will not be over an inch in depth. Follow with the next, using about the same proportions as of the . first, and thus on until you have a proportion of each. Go back again and repeat the process, until the quantities weighed out are used up. If the entire mass is but six or eight inches in clepth, it will mix the easier. To mix, an iron-toothed rake may be used; cutting it down, and mixing it, and ending by throwing it together with a shovel. If well mixed, the entire mass will be of a uniform color. In 
many fertilizers, as I have stated before, all forms of potash, except the carbonate which is found in wood ashes, and one form of crude potash, can be safely mixed. with any fertilizer without loss of ammonia. My farmer friends will remember that I have before this recommended that potash in any form would be likely to do most good if spread on in the late autumn or early in the spring. When wood ashes are used as a source of potasli in formulas, I would spread it separately, harrowing it in, and raking in the remainder of the formulas.

\section{APPLYING FERTILTZERS.}

A man needs a little experience to get them evenly distributed. It is well to practise a bit at first. Suppose, for instance, we want to scatter six hundred pounds over an acre of land: that would be one pound to every seventytwo square feet, or a piece of land about eight and a half by eight and a half feet. If we desire to strew, say, three hundred pounds in the drill, the drills being three feet apart, there would be about fourteen thousand feet of drill to the acre, which would give one pound to about forty-five feet of row. One trouble to be met with in distributing fertilizers is the wind, which during the planting-season is apt to begin to blow as soon as the air gets warm in the morning, generally slacking up toward night. It is best, therefore, when pessible, to put several hands on to spread them, either early in the morning, or toward the close of day. Otherwise, it would be well to have a few buckets of water handy, and pour into the barrels enough at a time to gently moisten by stirring the contents of each, being careful to have them dry enough to clistribute freely. To mix them in the drill so that they will not burn the seed, I use often the thick top of a cedar-tree to which a stone has been securely fastened. This, dragged once 
through the bottom of the furrow, will mix Peruvian guano, or any fertilizer, so thoroughly that it will not injure the seed. It has been found in practice, and is now generally advocated by clealers in fertilizers, that, as a general rule, it is a better plan to use barn manure and fertilizer's together on the same crop, as far as circumstances will permit; using the barn manure broadcast, and the fertilizers in the drill or hill, to give the crop a start. In my own practice I have not paid much respect to the rule, and thus far am very well satisfied with the results. I believe that farmers, as a general rule, would do better for many crops to use their manure on their grass, and so get a good strard, and depend on this, turned under, for the bulliy regetable matter when using fertilizers; for most of the difference between fertilizer's and barn manure is the presence of a bulliy mass of vegetable matter in the latter, which not only acts mechanically to lighten heary soils, but frees the plant-food locked up in all soils; and this the sward would supply.

\section{THE SYSTEM OF MAYURING TITH UNLEACHED WOOD ASHES.}

The firm that probably sells the most unleached ashes in New England and the Middle States, Messi's. Munroe, Judson, \& Stroup, Ostwego, N.Y., gives the following directions for its use. As I know that excellent crops have heen raised by following a portion of their instructions, I will give them in full under their proper heads; though we must remember, that, although ashes contain all the mineral elements in plant-food, it is wholly lacking in nitrogen, and there must come a time when, the accumulation in the soil haring been used up, most crops will need to have nitrogen fed to them in the manure. 'They adrise for all crops, to aprly heavily the first year the full dollar 
value you would use of stable manure, and in after-years give a light dressing. The effect of ashes lasts two or three times as long as stable manure. They are especially valuable for fruit-trees, fruit, grass, onions, cabbage, melons, cucumbers, and potatoes. A thorough application calls for from 45 to 200 bushels per acre.

For Stratberries. - Apply, in early fall or before, 40 to 125 bushels per acre, spading in a little bone before they start in the spring.

For Potatoes. - Scatter from 21 to 57 bushels a foot wide over the drills after they are covered.

For Cors. - Harrow in 40 to 80 bushels per acre before planting; and, after covering the seed, spread 15 to 28 bushels on the top of the hills, covering a strip a foot wicle.

For Lawns, Meadows, or Pastures. - In fall or early spring, or soon after haying, spread from 25 to 125 bushels. If 125 are used, no more will be needed for several years.

In LAYING DOWN TO GRAss. - Broadcast 45 to 225 bushels, in summer or fall, to give it time to leach down. Next year plant with potatoes, top-dressing with from 12 to 18 bushels per acre. Next year sow to wheat or rye, and lay down to grass. No more fertilizer needed for eight or ten years.

For WheAt, Rye, AND OATs. - Broadcast from 85 to 170 bushels in Norember, and plough slightly under. In spring plough deeper, throwing it up to the surface, and harrowing it; or, for the immediate crop, 20 bushels may be harrower in, in the spring: but in the long run the larger use will be the more profitable.

For: Oxions. - Broadcast from 45 to 250 bushels in the fall, and plough them just under. In the spring plough them back to the surface, and harrow. If 250 bushels are 
used, 40 will do for the second year, 60 for the third, and 85 for the fourth.

For Cabbage axd Caulfelower. - Use from 12.5 to 200 bushels in early spring, harrowing it into the ploughed land. After the plants are four inches high, put half a pint around each hill before hoeing. By such an applica tion, cabbage can be raised several years in succession on the same soil. Apply 40 bushels, broadcast, the second year, 60 the third, and 85 the fourth; using also some earch year in the hill.

For Cucunbers and Meloxs. - Harrow in 88 bushels, and scatter a pint over the top of each hill.

FERTILIZERS EXCELLENT FOR VARIOUS CROPS, AND SUGGESTIONS.

For Strawberries, Raspberries, Peaches, ard Pears, and the Frutt Gardex axd Orchard GexERALLr. - There has been found nothing more satisfactory than the phosphoric acid and potash, with hut a small quantity of nitrogen. Bone that has heen treated with acid will act at once, but coarse steamed bone is more encluring. I have a pear-orchard in land that has naturally a good suyply of potash, that, being in a sickly condition, I treated to coarse steamed bone eight year's ago, with the result of producing a good growth of wood, and noble crops of fruit, while I could cut two good crops under it anniually ever since. (See Mr. Hunt's remarks, on 1). 67, on the advantage of the bone and potash application to such fruits.) It appears to be settled that the "yellows" on the peach-trees is caused by want of nourishment, there being especially a lacking of potash. Diseased trees have been cured by a liberal application of it.

Professor Penhallow advises, after stirring the soil. to apply per acre the following mixture, viz., sulphate of mag- 
nesia (hieresite), 25 pounds; muriate of potash, 100 to 150 pomurls; (lissolved bone-black, 450 pounds: omitting a space of a foot all about the tree. Instead of the muriate, probably 10 bushels of unleached wood ashes, with a peck of waste salt, might be used. Dr. Nichols recommencls the following as a good stock fertilizer, a good combination for all crops, five humdred pounds to be applied to the acre. Trhile he consiclers superphosphates as good for all crops, he considers them especially good for roots and cereals.

$\cdot \quad \cdot \quad \cdot \quad \cdot 40$

Sulphate of ammonia $. \quad . \quad . \quad . \quad .25$

Muriate of potash . $\quad . \quad$. . . . . . 25

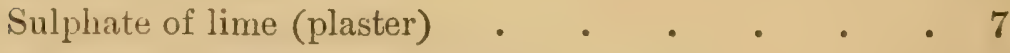

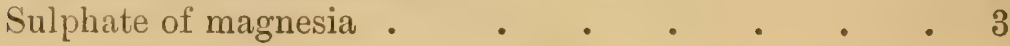

For Asparagus. - J. B. Moore, the well-known market garlener, has an acre and a half of asparagus on soil naturally very poor, mere pitch-pine land, which has, since broken up from nature, received no other dressing than phosphate of lime and potash. It is remarkably thrifty.

Fori Pasture-Laxd. - Raw ground lone will restore to the soil the phosphate of lime that has been carried away in the milk and in the bones of the young calf. Use finely gromol lome (not treated with acid) at the rate of four humdred to five hundred pounds per acre, and the effects will lie seen for rears. It is better to double the productiveness of a pasture than to double the area of it.

For Fritit-Trees ix Pasture-Laxd. - To Professor Maryuarl, of the Massachusetts $A$ gricultural College, I believe the pulblic will, as year's go on, realize that they owe a greal deht. The professur was the first, as far as I an aware, to agitate, and carry out in practice on something of a large scale, the idea of using for orcharding, 
waste land, rocky pastures, and hillsides which neither the plough nor manure cart could reach. This was marle practicable by the use of commercial fertilizer's. The professor's plan is, in brief, to dig holes three or four feet across, throwing out the earth to the requisite depth, and then, with picks, loosening the soil eighteen inches cleener. if practicalble. Make a mixture of half bone, half potash, and, when planting, scatter about four good handfuls orer the soil thrown out before planting, and as much more in the holes when they are half filled up with earth. MIulch with waste hay or tan. Apply the same amount of manuring yearly for a few years, until the trees are well estalllished and in a thrifty condition. I have planted a hundred or more trees in this way on my waste hilly gasture-land, and am thus far pleased with their promise.

In Layixg Land dowe to Griss. - Finely ground bone harrowed in at the time of laying clown, at the rate of from five hundred to a thousand pounds to the acre, will be foumd to be an excellent manure, and a lasting one. If the bone is steamed, it cari be used in a coarser state. If the grass is light upland (such land is better for corn than grass), then have half of the bone in the form of acid phosphate. When wood ashes are accessible, test your upland, and manure a portion with a mixture of the two, using value for value of each, and be gorerned in the future by the results. In bone and ashes we have a conplete manure, all of the three elements being present.

Fon Conx. - In the valualle experiments inamguraterl by the Connecticut experimental station, in the experiments with barn manures and rarious fertilizer's on comn, it was found that the mixture of three hundred pounds of superphosphate with one hundred and fifty pounds of muriate of potash gave the greatest profit, though not the largest crop; the average yield in fifty-three experiments 
being a little over fifty bushels of shelled corn to the acre, while the cost of the fertilizers was not over eight dollars. A mixture of either fish or Lobos guano and muriate of potash has proved an excellent manure for large crops of corn. Try it at the rate of five hundred pounds of either variety of guano and one hundred and fifty pounds of the potash.

For Potatoes. - The summing-up of many experiments macle over a large area of country was, that the best manure for potatoes is five hundred and fifty pounds of Peruvian or fish guano, with one hundred and fifty pound of muriate of potash.

For Cottox. - For cotton in sandy uplands, the following mixture is said by Professor Dabney to have given excellent results: " 20 bushels dry earth, 250 pounds kainite, 400 pounds pure dissolved animal bone (or 600 pounds acid phosphate), and 100 pounds sulphate of ammonia, well mixed; 500 to 1,000 pounds to the acre."

For Wheat. - In using guano on wheat, it is recommended to use one-third in the drills at time of sowing; one-third early in the spring, to be lightly harrowed in; and one-third just before a lain, when the plants are eight or ten inches out of the soil.

For Grass on Gratx Crop. - Where finely ground bone only is used (we will remember there is no potash in this), an application is recommended by good authority, to vary with the condition of the soil, of from 600 to 1,200 pounds to the acre. The effect of this will be seen for several years.

\section{COMPOSTS.}

Our farmer friends in the South do more in making a class of composts which in their composition and concentration aplproach commercial fertilizers, than clo we of the North. And this is not to be wondered at, when on alnust erery farm they have cotton-seed, so rich in am- 
monia and phosphoric acid, while in a thickly wooded region there must be plenty of ashes to suplly potash, and almost in their midst lie the great phospluate beds of North and South Carolina and Georgia. We of the North, with our coarser materials, such as night-soil, fish-waste. sea manure, and the like, make composts, lut not nearly so rich, or approaching so near in character to the commercial fertilizers in the market. Professor Dalnner submits four valuable compost formulas, which I here present:

F.orifula No. 1.

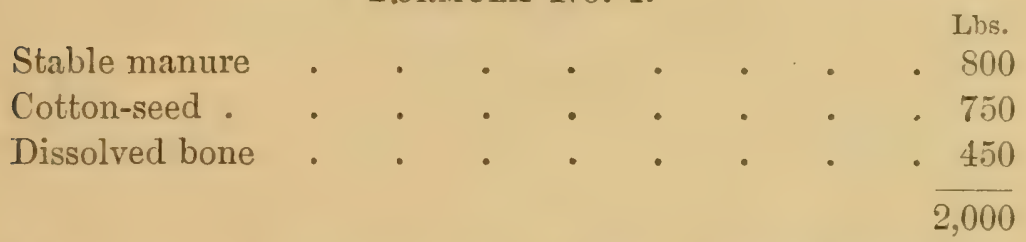

He advises in substance as follows: Have barn manure two inches deep, next the bone two inches, and then cotton-seed four inches. Wet the mass well with urine if possible, otherwise with water. Continue to repeat in same order until all the material is used. Corer the healy with dry earth or plaster. In from three to seren weeks the fermentation will have killed the cotton-seed. IThen using, pitch over, and mix thoroughly.

For Cottos. - For cotton, use 300 pounds per acre, half in the furrow, and half with the seed. On poor soil, use 400 to 500 pounds, -150 pounds with the seed.

For Conx. - Use one pint to the hill. If the land is in pretty good condition, use less. On sandy pine lands or old fields, add 75 pounds per acre of muriate of potash. When ashes are plenty, substitute these, — about 10 bushels unleached hard-iwood.

For Winter Wheat. - Use 400 to 500 pounds per acre. adding 50 pounds sulphate of potash dissolved in water. If the season is backward, add in the spring 100 pounds nitrate of soda. 
Formula No. 2.

Lbs.

Dry muck, peat, or soil .

Cotton-seed (twenty-two bushels). . . . . 600

Acid phosphate . . . . . . . . 600

Muriate of potash. • • • • • • . 100

Sulphate of ammonia • • • • • • $\frac{100}{2,000}$

Compost in same manner as No. 1 ; the muriate of potash and sulphate of ammonia being dissolved in water, and used to wet the heap.

For Wheat, Rye, or OATs. - Three hundred pounds to the acre. It may be harrowed in with the grain.

Formula No. 3.

Lbs.

Stable manure

Unburnt marl

Salt

Dissolved bones

Sulphate of potash

" "ammonia.

Mix in layers, or first mixing the marl and salt together thoroughly, and cover with it the compost of cotton-seed, stable manure, and dissolved bone; then sprinkle with the solution of sulphate of ammonia, and turn the whole over once in two weeks till fermented. Use as directed for Nos. 1 and 2.

Stable manure

Formula No. 4, for Tobacco.

Lbs.

Sulphate of potash . $\quad$ • . . . . 300

"6 " . . . . . . . 100

" " magnesia . . . . . 100

Dissolved bone . . . . . . . . 400

Land plaster • • • • • • • $\frac{100}{2,000}$

Use 400 to 500 pounds to the acre. In place of the potash, 80 bushels of hard-wood ashes may be substituted. Says the professor, "The formula for tobacco (No.4) is intenrled for those sections where cotton is not raised, and has met with marked success." 


\begin{tabular}{|c|c|c|c|}
\hline 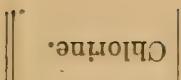 & 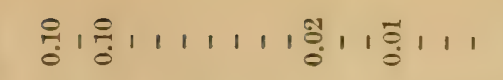 & 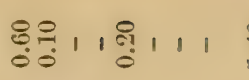 & 車 1111111 \\
\hline 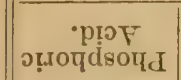 & 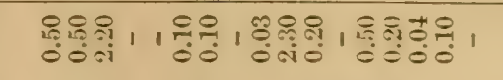 & 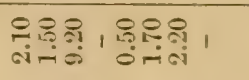 & 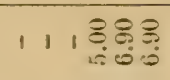 \\
\hline 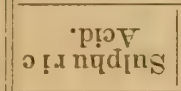 & 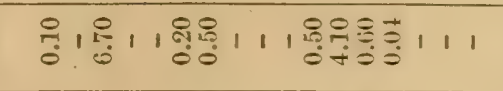 & 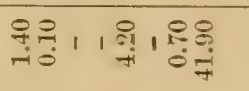 & 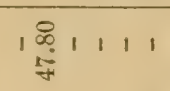 \\
\hline •вро & 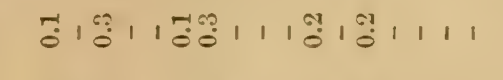 & 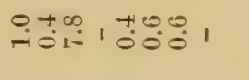 & '串1 1119 \\
\hline 'पूsษ० & 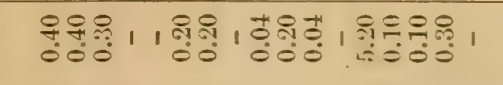 & 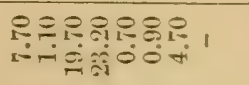 & , \\
\hline 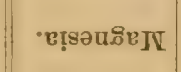 & 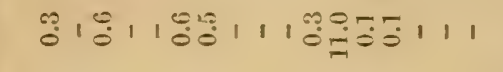 & 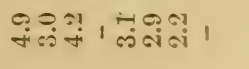 & $\begin{array}{llllll}1 & 1 & 1 & 1 & 1 & =\end{array}$ \\
\hline •әu! T & 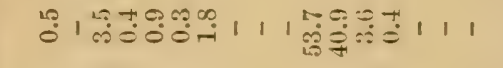 & 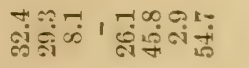 & $\begin{array}{lllll}1 & 1 & 1 & 1 & 0 \\
\end{array}$ \\
\hline 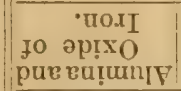 & 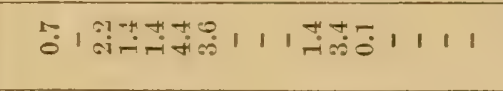 & 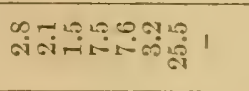 & $\begin{array}{llllll}1 & 1 & 1 & 1 & 1 & 1\end{array}$ \\
\hline 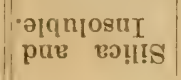 & 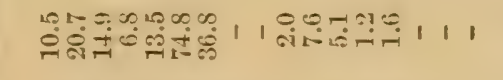 & 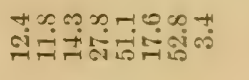 & $1 \overbrace{0}^{\infty} 1=011$ \\
\hline 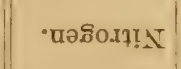 & 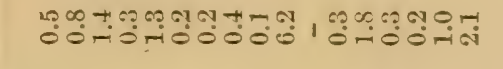 & $111118: 111$ & 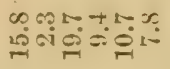 \\
\hline - $\mathrm{HSY}^{-1}$ & 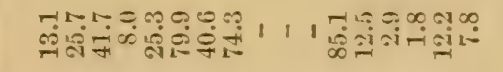 & $\begin{array}{lllllllll}1 & 1 & 1 & 1 & 1 & 1 & 1 & 1\end{array}$ & 1111111 \\
\hline 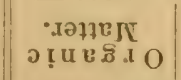 & 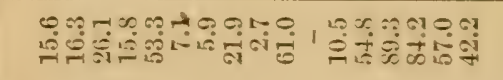 & 11111111111 & 111111 \\
\hline 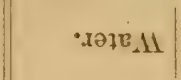 & 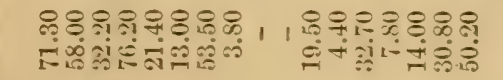 & 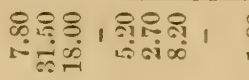 & 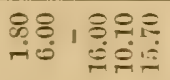 \\
\hline & 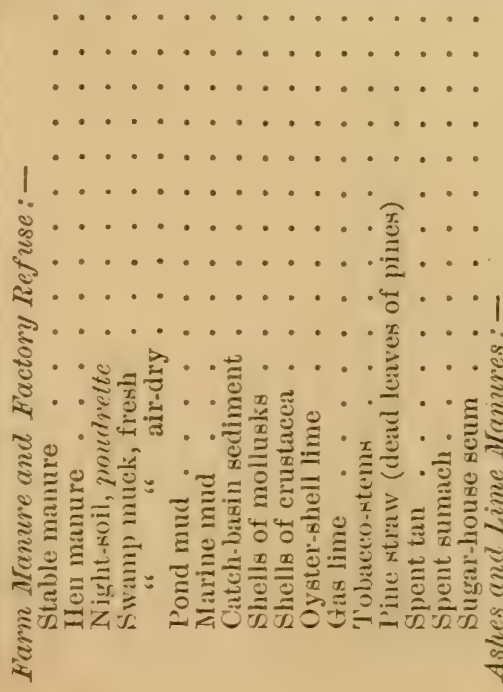 & 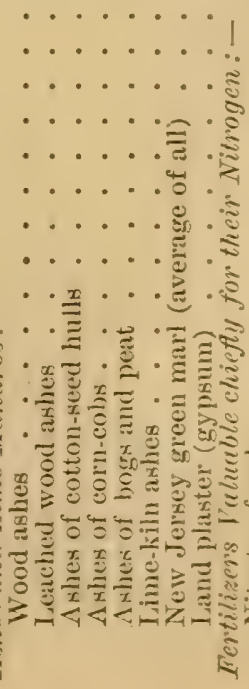 & 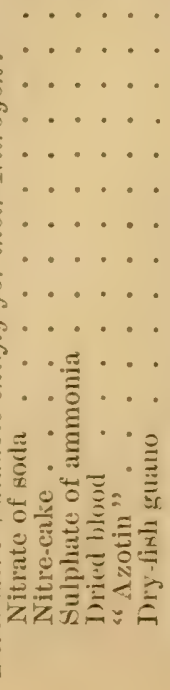 \\
\hline
\end{tabular}




\begin{tabular}{|c|c|c|c|}
\hline •әŭฺ.кор & $\begin{array}{lllllllll}1 & 1 & 1 & 1 & 1 & 1 & 1 & 1 & 1\end{array}$ & 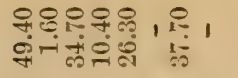 & 11118111111111111 \\
\hline 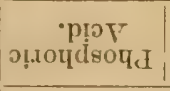 & 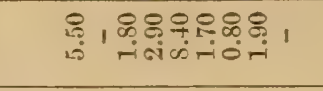 & $\begin{array}{llllllll}1 & 1 & 1 & 1 & 1 & 1 & 1 & 0 \\
\end{array}$ & 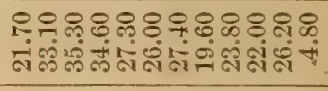 \\
\hline 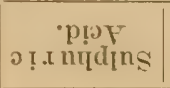 & $11111,80.11$ & 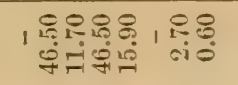 & 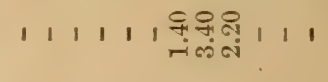 \\
\hline 'थpos & $\begin{array}{llllllll}1 & 1 & 1 & 1 & 1 & 0 & 1 & 1\end{array}$ & 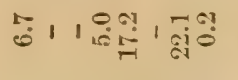 & 111111111111 \\
\hline 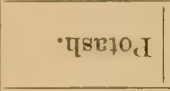 & 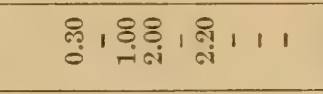 & 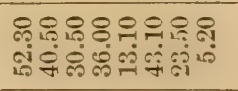 & 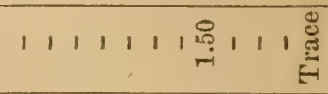 \\
\hline ' "!̣อuลิ & 1111100011 & 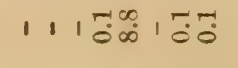 & 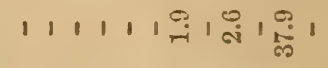 \\
\hline •әп!т & 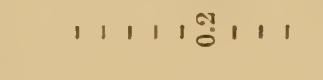 & 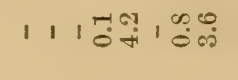 & 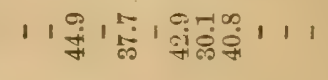 \\
\hline 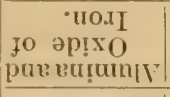 & $11111 \stackrel{0}{0} 111$ & $\begin{array}{llllllll}1 & 1 & 1 & 1 & 1 & 1 & -7 & 0\end{array}$ & $\begin{array}{lllllllll}1 & 1 & 1 & 1 & 1 & 1 & 1 & 1 & 1 \\
\end{array}$ \\
\hline 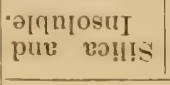 & $111119 \stackrel{109}{1} 11$ & 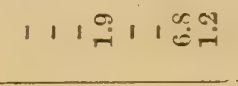 & | \\
\hline 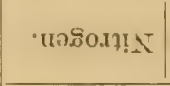 & 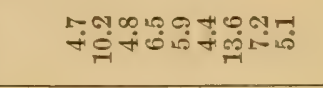 & 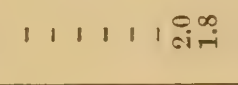 & 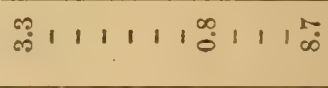 \\
\hline - पs & $\begin{array}{lllllllll}1 & 1 & 1 & 0 & 0 & 1 & 1 & 1\end{array}$ & $\begin{array}{lllllll}1 & 1 & 1 & 1 & 1 & 1 & 1 \\
\end{array}$ & 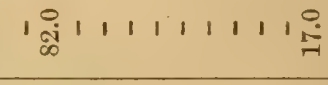 \\
\hline 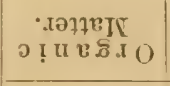 & $\begin{array}{llllllll}1 & 1 & 1 & 1 & 15 & 1 & 1 & 1\end{array}$ & $\begin{array}{lllllll}1 & 1 & 1 & 1 & 1 & 1 & \frac{0}{10} \\
10 & & & & \end{array}$ & 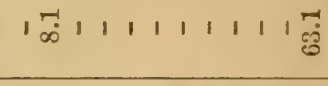 \\
\hline • Хวุย. & 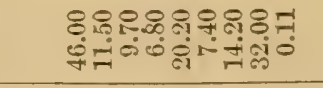 & 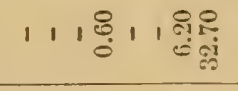 & 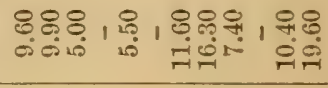 \\
\hline & 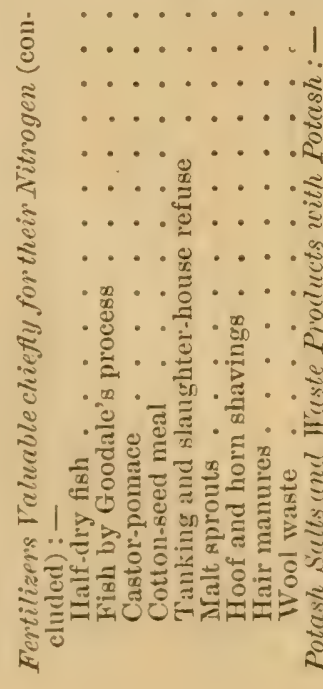 & 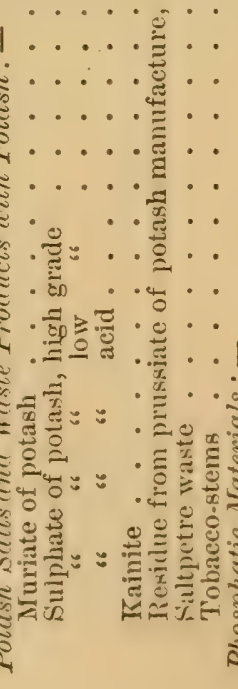 & 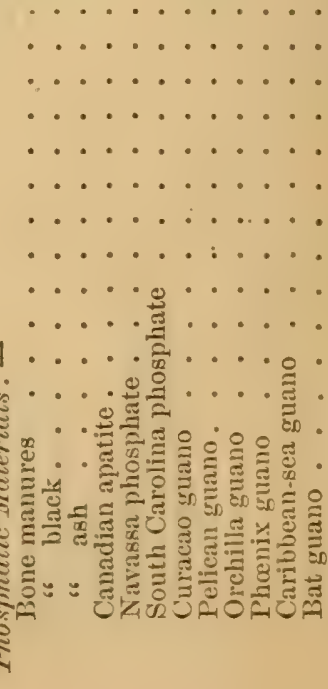 \\
\hline
\end{tabular}


The table is very interesting and instructive, and will bear a good deal of studying. Notice how many substances, in their percentages of nitrogen, potash, and phosphoric acid, approach in value stable manure. Notice that the humus-making capacity (the organic matter) of dry muck is three times as great as in stable manure. To make the potash and lime in oyster-shells and mollusks available for plant-food, they must be burnt. In marine mud it is probably the nitrogen and alumina only that are available; the mineral matter, mostly fragments of shells, being insoluble. As a rule, the per cent of organic matter in the several substances is a measure of their humus-making capacity. Note that all the substances that are the product of combustion contain no nitrogen: combustion destroys nitrogen.

Corn-cobs, as will be seen, are amazingly rich in potash; but the quantity of ashes from them is amazingly small. The potash in the ashes from a bushel of colss is worth a little scant of one-third of a cent. Note that decayed vegetable matter, in its various forms, is much the same in the proportions of the three elements.

Let us bear in mind that the nitrogen in the different substances varies greatly in its value, depending on its availability: for instance, that in horn, hoof, and hair is worth not over ten cents per pound, while that from blood, castor-pomace, and cotton-seed meal is worth not far from eighteen cents. Note that there is no potash in the lime manures, phosphates, and phosphatic guanos.

The following table is copied from an excellent little pamphlet on the cultivation of potatoes, issued by the Napes Formula Company, 158 Friend Street, New Tork. It shows the value of the plant-food taken out of the soil ly rarious crops. It is very valuable to us farmers, by enabling us to determine whether or not we are increas- 
ing the fertility of our soils. If the value of the phosphoric acid, potash, and nitrogen in the plant-food we apply is less than their value in the crop we take off, then we are robbing our land, and running down our farms, and vice versa. 'Take wheat, for an illustration. The valuc of these three elements in both stock and grain taken from the soil (assuming that one-half of the nitrogen is obtained from the air) is 34 cents per bushel, or $\$ 8.50$ in a crop of twenty-five bushels. Now, whether we are improving or robbing our land turns on the fact of our having put on more or less than $\$ 8.50$ in fertilizers, and in the proportion indicated by the analysis.

\section{ESTIMATES OF COST OF PLANT-FOOD IN CROPS.}

The phosphoric acid and potash are figured at the full quantities contained in the crops; but the nitrogen is figured at one-half or less, assuming the balance to be furnished by the soil and atmosphere, which is in accordance with the tendency of the results of modern scientific investigation.

In practice, on many soils half-rations of potash are ample; but, in the case of the phosphoric acid, its deficieucy in nearly all soils calls for full rations to be supplied from outside sources.

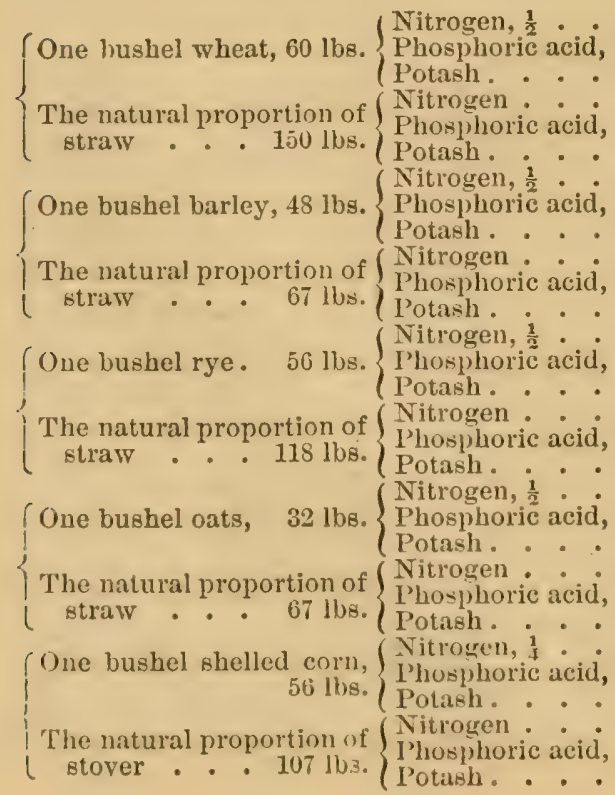

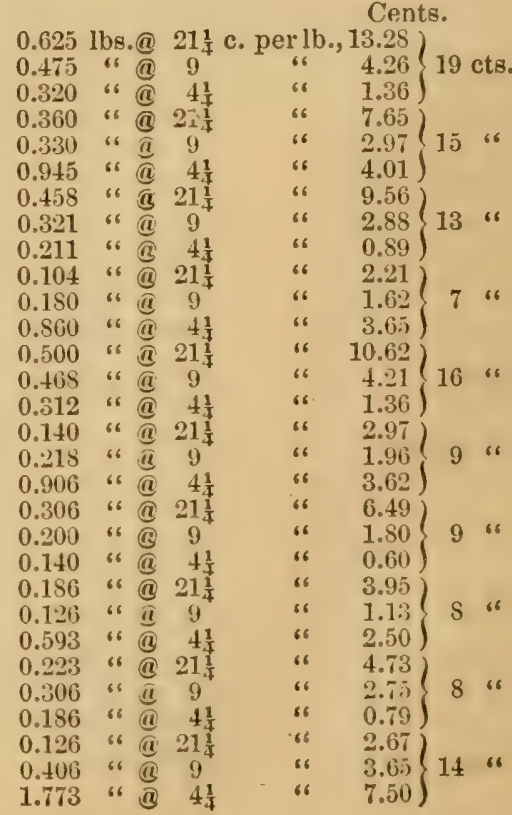


Cents.

f One bushel potatoes (tul- Nitrogen, $\frac{1}{2}$ - 0.097 lbs. (a) $21 \frac{1}{7} \mathrm{c}$. per 1b., 2.06

\begin{tabular}{|c|c|c|c|c|c|c|}
\hline bers). . $60 \mathrm{lbs}$. & hosphoric acid, & $\begin{array}{l}0.106 \\
0.336\end{array}$ & “ब & “6 & $\begin{array}{l}0.95 \\
1.32\end{array}$ & $4 \mathrm{cts}$. \\
\hline bushel buckwh & & 0.172 & " (a) $21 \frac{4}{4}$ & & 3.66 & \\
\hline $\begin{array}{r}\text { ne Dusnet ouckirneat, } \\
45 \text { lbs. }\end{array}$ & $\begin{array}{l}\text { Phosphoric acid, } \\
\text { Potash. - . }\end{array}$ & $\begin{array}{l}0.273 \\
0.129\end{array}$ & “ & “6 & $\begin{array}{l}2.45 \\
0.54\end{array}$ & 7 “ \\
\hline The natural proportion of & gen . • • & $\begin{array}{l}0.216 \\
0 . \pm 06\end{array}$ & " $\frac{a}{a} 21 \frac{1}{4}$ & “6 & & \\
\hline & & $\begin{array}{l}0.700 \\
1.613 \\
0.053\end{array}$ & “6 @ $21 \frac{1}{4}$ & “6 & $\begin{array}{l}3.00 \\
6.85 \\
1.12\end{array}$ & \\
\hline One bushel onions, $50 \mathrm{lbs}$. & Phos & $\begin{array}{l}0.077 \\
0.084\end{array}$ & 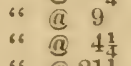 & “" & $\begin{array}{l}0.69 \\
0.35\end{array}$ & $2 "$ \\
\hline Ury-leaf tobacco, $100 \mathrm{lbs}$. & $\begin{array}{l}\text { Nitrogen, } \frac{1}{2} \text {. } \\
\text { Phosphoric acid, } \\
\text { Potash. }\end{array}$ & $\begin{array}{l}1.9+4 \\
0.59 .5 \\
5.6: 34\end{array}$ & 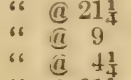 & "“ & $\left.\begin{array}{r}41.31 \\
5.3 .5 \\
23.94\end{array}\right\}$ & \\
\hline $\begin{array}{l}\text { The natural proportion of } \\
\text { stalk . } . ? \quad 87 \text { lbs. }\end{array}$ & $\begin{array}{l}\text { Nitrogen } \\
\text { Phosphoric acid, } \\
\text { Potash }\end{array}$ & $\begin{array}{l}1.305 \\
1.156 \\
3.717\end{array}$ & 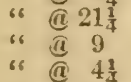 & "6 & $\left.\begin{array}{l}27.73 \\
10.67 \\
15.79\end{array}\right\}$ & \\
\hline $\begin{array}{r}\text { Seed cotton (334 lbs. lint), } \\
1,000 \mathrm{lbs} \text {. }\end{array}$ & $\begin{array}{l}\text { Nitrogen, } \frac{1}{12} \\
\text { Phosphoric acid } \\
\text { Potash. }\end{array}$ & $\begin{array}{r}2.583 \\
9.600 \\
11.066\end{array}$ & 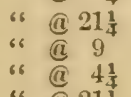 & "6 & & $\$ 1.59$ \\
\hline One ton meadow hay & $\begin{array}{l}\text { Nitrogen, } \frac{1}{2} \\
\text { Phosphoric } \\
\text { Potash . }\end{array}$ & $\begin{array}{r}16.000 \\
8.200 \\
23.340\end{array}$ & 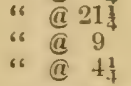 & “" & $\left.\begin{array}{r}3.18 \\
0.74 \\
99.19\end{array}\right\}$ & $\$ 1.0311$ \\
\hline One bushel pease, $60 \mathrm{lbs}$. & $\left\{\begin{array}{l}\text { Nitrogen, } \frac{1}{12} \\
\text { Phosphoric acid, } \\
\text { Potash }\end{array}\right.$ & $\begin{array}{l}0.179 \\
0.512 \\
0.588\end{array}$ & 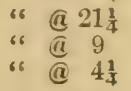 & “6 & $\left.\begin{array}{l}3.80 \\
4.50\end{array}\right\}$ & $11 \mathrm{cts}$. \\
\hline One bushel beans, $62 \mathrm{lbs}$. & $\left\{\begin{array}{l}\text { Nitrogen, } \frac{1}{12} \\
\text { Phosphoric acid, } \\
\text { Potash. }\end{array}\right.$ & $\begin{array}{l}0.210 \\
0.734 ; \\
0.809\end{array}$ & $\begin{array}{ll}\text { " } & \text { @ } 21 \frac{1}{4} \\
\text { " @ } & 9 \\
\text { (c) } & 4 \frac{1}{4}\end{array}$ & “6 & $\left.\begin{array}{l}4.46 \\
6.60 \\
3.63\end{array}\right\}$ & 14 \\
\hline
\end{tabular}

\section{A PLEA FOR MERCY.}

Though repeatedly urged to write this treatise by the Essex County Agricultural Society, I excused myself again and again, not only from a feeling of lacking ability to do the sulbject full justice, but also for the solid reason that it would bring down on my defenceless head a shower of correspondence asking advice and instruction on the many questions which will arise in individual experience; for, on a subject so rich in its many phases, it would be impossible to write a work that would anticipate all matter in which its readers might like information. Now, it is the most natnral thing in the world that my good friends should desire to ask these questions: I should were I in their place. But if they will please turn about, and put themselves in my place, and consider not only the time that would be required to perform the mere manual labor of answering such letters, but the thought and study that 
would be necessary to give intelligent replies, I have no doubt but that they would unanimously concede to me the right to put in this plea for mercy. I suppose the able men at the head of our experimental stations will hardly thank me; but I would, sotto voce, suggest to my friends, that, if questions must be asked, they switch the vast freight on to their track, and so send them to abler heads and freer hands than mine, - to those whose business it is to make such investigations as would supply the facts needed in the answering of this class of questions. Such as I may receive, I propose to pigeon-hole until some future time, when I may get out a book on barn manure and the various wastes used as manures (in which, living near great manufacturing centres, I have chanced to have a large experience), and, either in the body of such treatise or in its closing chapters, reply to my correspondents. 


\section{CONTENTS.}

Introduction $\quad \cdots \quad \ldots$

Difference between Barn Manure and Commercial Fertilizers . . . 6

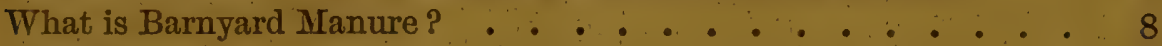

Humus . . . . . . . . . . . . . . . . 12

Are Fertilizers but Stimulants? . . . . . . . . . . 13

Potash . • • • . . . . . . . • . . . . . 16

WVood Ashes . • • . . . . . . . . . . . . . . . 23

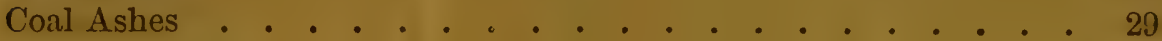

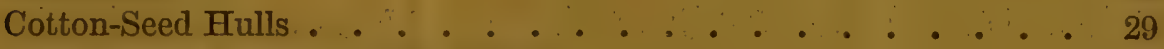

The Uses of Potash in Agriculture . . . . . . . . . . . 30

What is Nitrogen?

Where Nitrogen or Ammonia comes from . . . . . . . . . . 35

How to Handle Fish-Waste, and the Best Way to Feed it to the Crops, 40

Other Sources for Nitrogen . . . . . . . . . . . . 44

Phosphoric Acid . . . . . . . . . . . . . . . . . 54

Bones, and where they come from . . . . . . . . . . 57

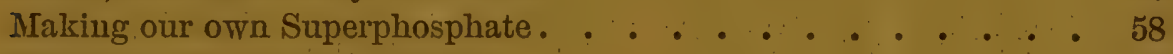

Reduction of Unground Bone........ .64

The Theories of Fertilizing . . . . . . . . . . . . 68

Testing our Soils

A Faith that is Dangerous; Buying Cheap Fertilizers . . . . . 74

Making our own Fertilizers .

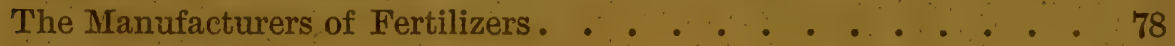

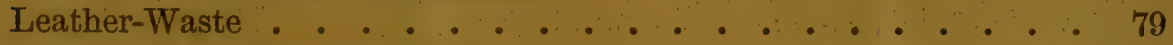

Some Facts and Suggestions . . . . . . . . . . . . . 81

Fertilizing Ingredients in Raw Materials and Chemicals . . . . . 84

Commercial and Agricultural Values of Fertilizers . . . . . . 86

Where to Obtain our Fertilizing Material at the Lowest Cost . . . 86

Formulas, and how to Compound them . . . . . . . . 90

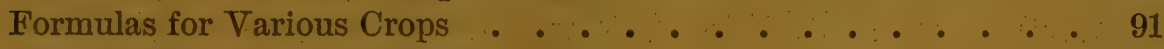

How to Compound our own Formulas . . . . . . . . . . 94

Some Formulas as Compounded ... . . . . . . . . . . . 96

Condensation of Special and other Formulas . . . . . . . . 98

How to Mix the Ingredients that enter into a Formula . . . . . 101

Applying Fertilizers . . . . . . . . . . . . . . 102

The System of Manuring with Unleached Wood Ashes . . . . . 103

Fertilizers Excellent for Various Crops, and Suggestions . . . . 105

Composts - . . . . . . . . . . . 108

American Analyses of Composition of Fertilizing Materials . . 111, 112

Estimates of Cost of Plant-Food in Crops . . . . . . . . 114

A Plea for Nercy . . . . . . . . . . . . . . 115 


\section{AGRICULTURAL TREATISES}

WRITTEN BY J. J. H. GREGORY, MARBLEHEAD, MASS.,

SEED-GROWER AND SEED-DEALER.

** Single copies of either of the four following treatises sent by mail for 30 cents, or the four for $\$ 1$. Seed-dealers and book-sellers supplied at the usual discount.

\section{ONION - RAISING :}

WHAT KINDS TO RAISE, AND THE WAY TO RAISE THEM.

This work has gone through fifteen editions. It trents on onions raised from seed, potato onions, onion-sets, top onions, shallots, and rareripes; tise onion maggot; rust; the merits of the different varieties of onions; instructions in seed-raising, and how to tell good seed, beginning with the selecting of the ground, and carrying the reader along, step by step, throngh the preparing of the soil, manuring, ploughing, planting, hoeing, weeding, gathering the crop, storing and marketing it, with a hundred minute details, embracing every department of the subject. Illustrated with thirteen engravings of onions, sowing-machines, and weedingmachines.

\section{SQUASHES, AND HOW TO GBOW THEM.}

This treatise contains several illustrations, including a section of my squash-house, with full directions for erecting one. In plan it is very minute and thorough. Beginning with the selection of soil, it treats of the best way of preparing it; the best manures, and the way to apply them; planting the seed; protecting the vines from bugs and maggots; the cultivation, gathering, storing, and marketing of the crops, - giving hundreds of minute details so valuable to inexperienced cultivators.

\section{CABBAGES, AND HOW TO RAISE THEM.}

This treatise begins with the selecting of the ground, and carries the rearler along, step by step, through the preparing of the soil, manuring, ploughing, planting, hoeing, weeding, gathering the crop, storing and marketing it, with a hundred minute details, embracing every department of the subject.

To prepare myself the more thoroughly to write on this work, I experimented on foreign and native varieties of cabbage for four years, raising not far from seventy kinds. It is illustrated by several fine engravings. I have adcled a paragraph on the green worm, that is causing so much trouble in some localities:

\section{CARROTS, MANGOLD WURTZELS, AND SUGAR BEETS :}

WHAT KINDS TO RAISE, HOW TO GROW THEM, AND HOW TO FEED THEM.

In writing this treatise, $\mathrm{I}$ have encleavored to give that minuteness of detail in every step of progress, from the seed to the matured crop, that is generally desired by the public. While this work is more partieularly intended for persons of limited experience, yet it gathers up so much of experience and observation, covering so much ground in the growing and landling of these two standard crops, that I should he disappointed if about every grower did not find within its covers some facts of wore value to him than the cost of the book. 






\section{LIBRARY OF CONGRESS

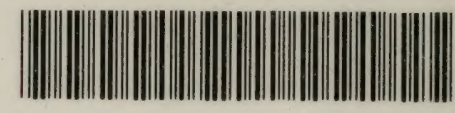 00027554064}

